\title{
TRIAL AS ERROR, JURISDICTION AS INJURY: TRANSFORMING THE MEANING OF ARTICLE III
}

\author{
Judith Resnik
}

\section{TABLE OF CONTENTS}

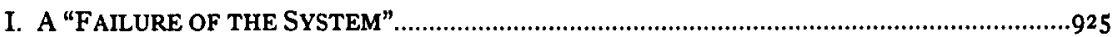

II. JUDICIAL TRANSFORMATIONS OF THE DAILY PRACTICES OF JUDGING .........................933

A. Procedural Aspirations and Sources...............................................................................935

B. A Corporate Structure, Large Scale Litigation, and More Cases..................................937

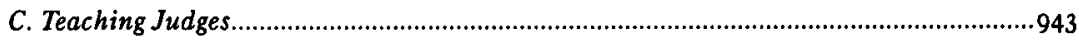

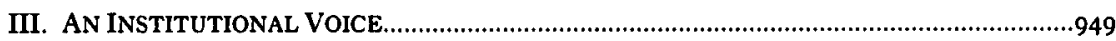

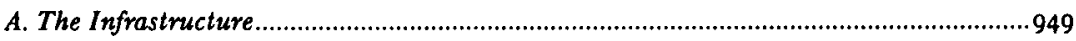

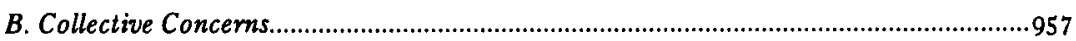

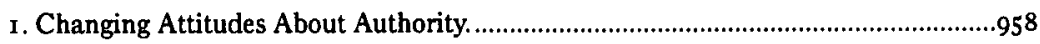

2. Redefining the Work Appropriate for Life-Tenured Judges.....................................967

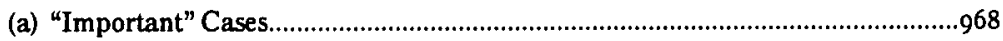

(b) Identity by Association.................................................................................970

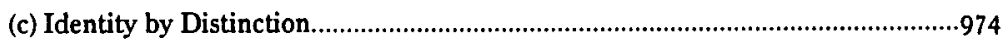

(d) The Quantities and Kinds of Federal Judges ...................................................983

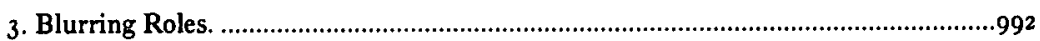

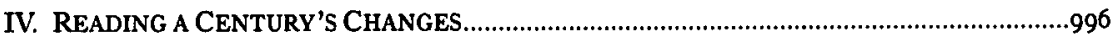

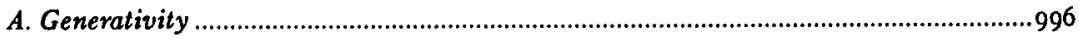

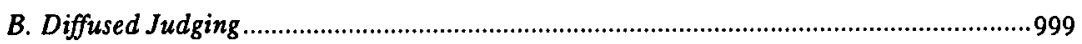

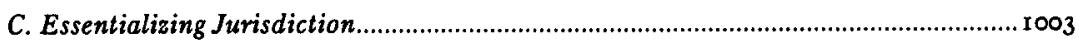

V. REREADING ARTICLE III .....................................................................................

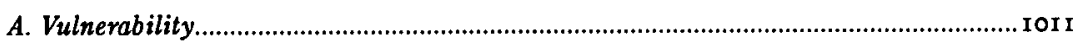

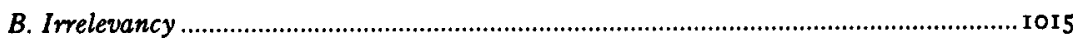

VI. CACOPHONY, FOR A PECULIAR BRANCH OF GOVERNMENT …...................................

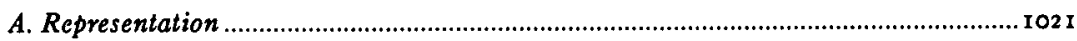

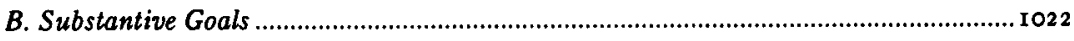

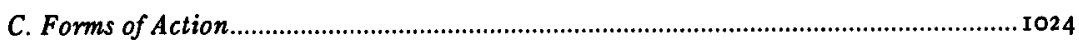

VII. THE ICONIC COURTHOUSE ................................................................................. 


\title{
TRIAL AS ERROR, JURISDICTION AS INJURY: TRANSFORMING THE MEANING OF ARTICLE III
}

\author{
Judith Resnik*
}

\section{A "FAILURE OF THE SySTEM"}

In the fall of 1994, the Los Angeles Federal Bar Association held a meeting for some hundred lawyers to discuss then-recent changes to the rules that govern the processes of litigation in the federal court system. At that time, of one hundred civil cases commenced in federal court, about eight started trial; the remaining ninety-two ended in other ways. ${ }^{1}$ Introducing the program, a federal district judge stated that he regarded the eight percent trial rate as evidence of "lawyers' failure."

- Arthur Liman Professor of Law, Yale Law School. My thanks for help in thinking about the issues discussed here to Dennis Curtis, Vicki Jackson, Bruce Ackerman, Lincoln Caplan, Owen Fiss, John Frank, Deborah Hensler, Lisa Kloppenberg, John Langbein, Henry Monaghan, Edward Purcell, Tanina Rostain, Eugenia Toma, Elizabeth Warren, Stephen Yeazell; to Eric Biber, Steven Engel, Kim Demarchi, Megan Johnson, Matthew Kutcher, Kristin Martin, Eric Shumsky; to Richard Arnold, Martha Craig Daughtrey, Gladys Kessler, Brenda Murray, Ellen Peters, Michael Ponsor, Philip Pro, David Tevlin, William Young, and Douglas Woodlock; and to participants at faculty workshops at Yale Law School and at the University of Miami School of Law.

Special thanks is owed to staff members at the National Archives, the Federal Judicial Center, the Administrative Office of the U.S. Courts, the State Justice Institute, and the Sterling Library and especially to Gene Coakley of Yale Law School's library, for all their generous assistance in making source materials available. An earlier version of this essay was given as a lecture at the inauguration of the Arthur Liman Professorship, the chair of which I am the first holder. I have the honor of invoking Arthur Liman's name in conjunction with my own.

1 Estimates vary depending on the ways in which data from the Administrative Office of the U.S. Courts (AO) are evaluated. The eight percent figure is derived by combining, for the year ending in September of 1994 , the cases "terminated during/after trials" $(7,910)$ with those in which trials were "completed," $(10,473)$ and then using the numbers of cases "commenced" $(236,391)$ in the same year as the baseline, resulting in a $7.8 \%$ trial rate. See ADMINISTRATIVE OFFICE OF THE U.S. COURTS, I 994 ACTIVITIES OF THE ADMINISTRATIVE OFFICE OF THE UNITED STATES CourTS app. at I-8I tbl.C-4A, app. at I-9o tbl.C-7, app. at I-48 tbl.C.

Of course, the trials held in 1994 may not be in cases commenced in that year. While about half of the cases "close within 9 months of filing," the rest remain pending longer. JAMES S. Kakalik, Terence Dunworth, Laural A. Hill, Daniel McCaffrey, Marian Oshiro, Nicholas M. PaCe \& Mary E. Vaiana, AN Evaluation of Judicial Case Management UNDER THE CIVIL JUSTICE REFORM ACT 158-64 (RAND 1996) [hereinafter RAND JUDICIAL CASE MANAGEMENT Evaluation]. The average time from filing to disposition in cases tried was about 16 months. See AdMINISTRATIVE OfFICE of THE U.S. CoURTS, JUdicial BuSINESS OF THE UNITED STATES COURTS at tbl.C-10 (1994). Therefore, the eight percent rate provides a snapshot of the likelihood of trial rather than describing which cases went to trial. 
That got my attention: a person whose title was "trial judge" equated going to trial with failure. His relevance rests on the fact that he is not alone. Found in reported decisions is the phrase "a bad settlement is almost always better than a good trial."2 Found in rules and policy statements of the federal judiciary are increasing obligations of judges to press parties toward settlement. For example, a local rule in the federal trial courts of Massachusetts requires a judge to raise the topic of settlement at every conference held with attorneys. ${ }^{3}$ Moreover, this growing law of settlement is not simply hortatory. Court rules and statutes require litigants and their lawyers to engage in a variety of settlement processes; ${ }^{4}$ penalties flow from failure to comply. ${ }^{5}$

The internal rhetoric and rules of the federal judiciary stand in contrast to discussions in law, politics, and popular culture about the federal judiciary. Since the country's founding, the federal courts have been identified as an important participant in national governance. The United States Constitution sets the judiciary apart as a distinct branch of government charged with exercising judicial power under a

2 See, e.g., Hispanics United v. Village of Addison, 988 F. Supp. I 130,1149 (N.D. Ill. I997) (citing In re Warner Communications Sec. Litig., 618 F. Supp. 735, 740 (S.D.N.Y. 1980)) (also describing the phrase as a "familiar axiom"); Strong v. BellSouth Telecomm, Inc., 173 F.R.D. I67, I 72 (W.D. La. 1997) (observing that "[i]n this case, I could hold my nose and accept the settlement, after all, it is said that a bad settlement is better than a good trial"); Weiss v. Mercedes-Benz of $\mathbf{N}$. Am., Inc., 899 F. Supp. I297, I30I (D.N.J. 1995) (approving a "coupon" settlement and commenting that it was not "bad" given the "arm's length negotiation between two very capable parties").

3 See DIST. MASS. LOCAL R. 16.4(A) ("The judicial officer shall encourage the resolution of disputes by settlement or other alternative dispute resolution programs."); $i d$. I6.4(B) ("At every conference conducted under these rules, the judicial officer shall inquire as to the utility of the parties' conducting settlement negotiations ...."). This rule stemmed in part from congressional encouragement of such approaches through the I9go Civil Justice Reform Act (CJRA), 28 U.S.C. $\$ 47$ I (1990), which requires each district to implement a "justice expense and delay reduction plan" to "facilitate deliberate adjudication of civil cases on the merits, monitor discovery, improve litigation management, and ensure just, speedy, and inexpensive resolutions of civil disputes"; this legislation had a sunset provision. See id. $\$ 482(\mathrm{~b})(2)$; see also The Civil Justice Reform Act of 1990 Sunsets Next Month, THIRD BRANCH, Nov. 1997, at 6.

In 1998, Congress reiterated and sharpened the obligations of federal courts to require litigants to consider settlements. See Alternative Dispute Resolution Act of 1998, 28 U.S.C. \& 65 I(a), (b) (Supp. IV 1998) (defining "alternative dispute resolution" (ADR) to include "any process or procedure, other than an adjudication by a presiding judge, in which a neutral third party participates to assist in the resolution of issues in controversy," and requiring all district courts to authorize the use of ADR and to mandate that litigants be provided with at least one such ADR option to consider).

4 See, e.g., FED. R. CIV. P. I6(c) ("[T]he court may require that a party or its representative be present or reasonably available by telephone in order to consider possible settlement of the dispute.").

5 See id. I6(f) (authorizing sanctions for failure to comply, such as orders affecting the litigation and awarding attorneys' fees to opponents); Schwarztmann v. ACF Indus., I67 F.R.D. 694, 699-700 (D.N.M. I996) (ordering the parties to continue settlement discussions, sanctioning the U.S. for failing to send a fully authorized representative to settlement conferences, and requiring the U.S. to "craft a settlement procedure" for all cases in that district as well as to participate in negotiations about the specific case and to pay attorney fees). 
tripartite system of separated powers. Judges and lawyers fly the globe to propose that other nations adopt constitutions that guarantee similar structural protection for judges. ${ }^{6}$ Since the Civil War, Congress has authorized the federal judiciary to rule on a widening range of problems. Over the course of this century, law schools have come to emphasize the centrality of the federal judiciary and to stress that one of its distinctive features, life-tenure, is exemplary of the principle of judicial independence. Legal and popular culture portray federal judges as solemn and deliberate - sometimes assuming heroic proportions. ${ }^{7}$

Trials are thought to be the centerpiece of this judicial process, offering (now to a wider audience by means of television) vivid images of law in action. The visual dominance of trials in the popular landscape reflects a political conception that laws' processes should be accessible to the public. In the United States, the public presumptive right of attendance at trials identifies adjudication as a specific form of decisionmaking performed in a public venue. ${ }^{8}$

But the legally enforced visibility of trials, enhanced by the media's showcasing of trials, ${ }^{9}$ misleads. As the eight percent rate invoked in

6 The American Bar Association's Central and East European Law Initiative (CEELI) is illustrative. See, e.g., Central and Easterm Europe, CEELI UPDATE (ABA/Cent. \& E. Eur. Law Initiative, Washington, D.C.), Spring I998, at 3-18 (detailing assistance provided to several countries).

7 Hercules is one (gendered) image offered. See RONALD DWORKIN, LAW'S EMPIRE $239-66$ (1986). Bravery of federal judges has sometimes been linked to implementation of antisegregation rulings. See JaCk BASS, Unlikely Heroes: THE DRAMATIC STORY OF THE SOUTHERN JUDGES OF THE FIFTH CIRCUIT WHO TRANSLATED THE SUPREME COURT'S BROWN DECISION INTO A REVOLUTION FOR EQUALITY (198I); see also Jack Bass, John Minor Wisdom, Appeals Court Judge Who Helped to End Segregation, Dies at 93, N.Y. TIMES, May 16, 1999, at 45; Robert D. McFadden, Frank M. Johnson, Jr., Judge Whose Rulings Helped Desegregate the South Dies at 80, N.Y. TIMES, July 24, I999, at AI2.

8 Exactly when such a right attaches is the subject of case law and commentary, with distinctions drawn between civil and criminal cases and between the trial and pretrial phases. See generally Judith Resnik, Due Process: A Public Dimension, 39 U. FLA. L. REV. 405, 409-20 (I987). Historical precedents for public enactment of government-imposed sanctions are discussed in Samuel Y. Edgerton, JR., Pictures and PUnishment: ART and CRIMinal Prosecution DURING THE FLORENTINE RENAISSANCE 65-68 (1985), which describes public humiliations as a means of demonstrating that an offender had violated the community's morality. For the role of such enactment in reflecting and creating the meaning of adjudication, see Pierre Bourdieu, The Force of Law: Toward a Sociology of the Juridical Field, 38 HASTINGS L.J. 8I 5, 838 (Richard Terdiman trans., 1987 ).

9 The federal judiciary is hesitant about televised court proceedings; state trials, rather than federal trials, are broadcast. See 1994 JUDICIAL CONFERENCE REPORT 46-47 (discussing a pilot project on broadcasting proceedings at trial and appellate courts and declining to approve a committee recommendation for cameras in courtrooms in civil cases). The Conference has not prohibited its Court Administration and Case Management Committee from "proposing pilot programs or conducting studies" about the use of cameras in civil cases. I995 JUDICIAL CONFERENCE REIORT 5-6. In 1996, the Conference agreed to "authorize each court of appeals to decide for itself" whether to permit coverage by television or radio and also urged each circuit to 
1 994 by the Los Angeles district court judge indicates, trials are increasingly rare events. In I 998 , of every one hundred civil cases filed in the federal courts, about six went to trial. ${ }^{10}$

An important addendum is, however, needed - a reminder not to equate the frequency of adjudication (decisionmaking by a judge) with the frequency of trials (by either judge or jury): while six of one hundred cases go to trial, the remaining ninety-four do not all settle. Some sixty or seventy do. ${ }^{11}$ The rest conclude through forms of adjudication other than trial, such as rulings by judges on contested issues of jurisdiction or on the viability of a legal claim. ${ }^{12}$ Moreover, within the set of cases that settle, issues may first be contested and decided by judges. Yet while a substantial amount of adjudication thus occurs in the federal courts, judges are increasingly steering litigants away from seeking decisions and towards negotiated agreements. ${ }^{13}$

adopt rules - consistent with the I 994 policy - about district court coverage. I996 JUDICIAL CONFERENCE REPORT 17 . Legislation to permit but not to require the broadcasting of federal court proceedings is pending. See H.R. 1281, 106th Cong. (1999).

The Judicial Conference and its predecessor, the Conference of Senior Circuit Judges, see infra notes 15,36 , produced reports annually. These reports were published initially (in 1924) by a law review, then in the Annual Reports of the Attorney General, and subsequently as independent documents, often bound with the Annual Reports of the AO. The titles of the Conference reports vary somewhat; in some years the report is denoted the "Annual Report of the Proceedings of the Judicial Conference of the United States," and in other years, simply the "Report of the Proceedings of the Judicial Conference of the United States." Further, the name of the Conference changed from the Conference of Senior Circuit Judges to the Judicial Conference of the United States. For brevity, I wil refer to each Judicial Conference report by its date, the title JUDICIAL CONFERENCE REPORT, and the relevant page. If the report is reprinted in another source, I will provide that information as well.

10 See ADMINISTRATIVE OFFICE OF THE U.S. COURTS, JUDICIAL BUSINESS OF THE UNITED STATES COURTS: I998 REPORT OF THE DIRECTOR 136 tbl.C [hereinafter I998 US CoURTS] (for year ending Sept. 30,1998$)(256,787$ cases commenced); id. at 166 tbl.C-4 $(6,783$ cases terminated during or after trial); id. at 178 tbl.C-7 $(9,349$ trials completed). About i2\% of criminal cases concluded through trial. See id. at 178 tbl.C-7, I95 tbl.D.

11 See Stephen C. Yeazell, The Misunderstood Consequences of Modern Civil Process, 1994 WIS. L. REV. 631,636 (finding that about "one-third of all federal civil cases" included "adjudicated dispositions" but that in $1938, " 63 \%$ of the adjudicated terminations of civil cases were trials and directed verdicts," while in 1990 , trials were "only i I\% of the adjudications," with other pretrial rulings making up the rest of the one-third adjudication rate).

Slightly different rates are provided in Marc Galanter's essay, Real World Torts: An Antidote to Anecdote, 55 MD. L. REV. 1093,1100 n.17 (1996), which discussed a data base of state and federal cases in which $7 \%$ went to trial, $24 \%$ terminated by other adjudication, and $69 \%$ ended by settlement. See also Sam Gross \& Kent D. Syverud, Don't Try: Civil Jury Verdicts in a System Geared to Settlement, 44 UCLA L. REV. I, 2 n.2 (I9g6) (citing an estimated national trial rate of $2.9 \%$ in state and federal courts). Greater specificity about the forms of judgments made at the trial level is made difficult by the ways in which termination data are coded.

12 See Patricia M. Wald, Summary Judgment at Sixty, 76 TEX. L. REV. 1897, I941-45 (I998) (describing how summary judgment has been transformed).

13 As the popular press now reports. See, e.g., Joseph B. Treaster, Insurer Must Pay $\$ 100.5$ Million in Redlining Case, N.Y. TIMES, Oct. 27, 1998, at CI (describing a "milestone decision" by a jury and noting that, according to the Executive Director of the plaintiff housing group, 
This article first explains how and why federal trial judges came to reorient the processes of judging and, in essence, to redefine their jobs by adding the management and settlement of civil cases to their judicial role. ${ }^{14}$ The background conditions for this shift were provided in the I 930 s by the creation of nationwide rules of procedure and the formation of organizational ties among federal judges. But the processes by which practices change require more than the pronouncement of new rules. This essay therefore also explores alterations in the content and size of the federal judiciary's docket and the creation of educational programs for judges to teach new and different norms of "good" judging.

The ability to articulate norms of judging depends upon having a "voice." After detailing the transformation of the daily practices of judging, I turn, second, to an analysis of an interrelated development: the creation of the corporate persona of the federal judiciary and the programs it has championed. Over the course of the twentieth century, the judiciary formed means of self-governance, selfadministration, and self-promotion. A council of judges, now called the Judicial Conference of the United States ${ }^{15}$ and aided by its own administrative staff, has taken on the role of articulating programmatic goals for the Article III judiciary including, as described above, settling cases.

I therefore trace the evolution, during eighty years of governance, of attitudes about the identity of the federal courts and the appropriate scope of commentary by the judiciary, qua judiciary, about the federal courts. While initially reluctant to argue for or against jurisdictional provisions, during the last forty years the Judicial Conference has come to embrace several policies relating to judgeships and jurisdiction. These policies entailed development of the concepts of the federal courts as a distinctive and unique venue, of life-tenured judges as

"[d]uring the two-week trial," the trial judge of the Circuit Court of the City of Richmond "urged the two sides to settle several times").

Academic literature also reflects the growing interest in the judicial role in settlement. See, e.g., Janet Cooper Alexander, Judges' Self-Interest and Procedural Rules: Comment on Macey, 23 J. LEGAL STUD. 647 (I994); Marc Galanter \& Mia Cahill, "Most Cases Settle": Judicial Promotion and Regulation of Settlements, 46 STAN. L. REV. 1339 (1994); Judith Resnik, Whose Judgment? Vacating Judgments, Preferences for Settlement, and the Role of Adjudication at the Close of the Twentieth Centary, 4 I UCLA L. REV. 147 I (1994); see also Stephen McG. Bundy, The Policy in Favor of Settlement in an Adversary System, 44 HASTINGS L.J. I (1992).

14 Although I will discuss the issue of "federalization," see infra pp. 980-81, my focus is neither on changes in the processing of criminal cases, see generally KATE STITH \& JOSE A. CABRANES, FEAR OF JUDGING: SENTENCING GUIDELINES IN THE FEDERAL COURTS (1998), nor on judge/jury relationships.

15 Created first in 1922 and called the Conference of Senior Circuit Judges, the body was renamed the Judicial Conference in 1948. See infra note 36. In this essay, I refer to both as the Judicial Conference or as the Conference. 
hierarchically superior to but able to share jurisdiction with non-lifetenured "federal" judges, and of the judicial branch as appropriately advising Congress and the country about whether to locate enforcement of new rights in the federal courts. Relying on these concepts, the Article III judiciary now supports the transfer of some of its juridical authority to adjudicators who lack life tenure through the delegation within the Article III branch to statutorily created bankruptcy and magistrate judges and by the assignment of certain kinds of cases to the growing administrative judiciary and to the state courts. Further, while initially reluctant to give opinions on proposals related to jurisdiction, during the last few decades the Judicial Conference has recorded its opposition to several jurisdictional provisions. The leadership of the federal judiciary now advocates alternative forms of and fora for federal adjudication, fewer routes for litigants to federal court, greater reliance on non-tenured federal adjudicators, and slow growth in life-tenured judgeships. The Judicial Conference has thus become a lobby against federal jurisdiction.

These "policy" positions interact with constitutional interpretations of Article III. By exploring the history of and constitutional doctrine concerning which actors have judgment powers under Article III, I demonstrate the degree to which the understanding of who is a "federal judge" has changed over the century. Pressed by the administrative state for adjudication, the life-tenured judiciary (working in conjunction with Congress) responded creatively by permitting the manufacture of more federal judges, albeit without life tenure. Through such lawmaking, the federal judiciary has become a fourtiered organization, populated at its lower echelons by hundreds of non-life-tenured judges who are statutory - as contrasted with constitutional - actors.

My third aim is to analyze the implications of the judiciary's programmatic achievements and constitutional decisions. How does the development of the federal judiciary as a politically active branch of the federal government fit the parameters of Article III and the allocation of functions within the Constitution? What is the difference between judges appearing as individuals before Congress and judges appearing as the embodiment of Article III? How does the iconic status of the life-tenured federal judge mesh with the daily world of federal judging, which is focused on settlement and populated by many judges without life tenure?

The answers to these questions require a reevaluation of Article III in terms of both its endowments to individuals and its conception of the judiciary as a branch of government. A claimed strength of Article III - independence provided through constitutional job security may be overprotective when it insulates judges who have redefined their work as facilitating settlements. In contrast, Article III seems inadequate when the focus shifts to the ever-growing powers of statutory 
judges and the increasingly heavy budgetary burdens stemming from the organizational expansion of the federal judiciary.

But before simply objecting to the very existence of non-Article III federal judges, appreciation for invention is in order, as are concerns about the implications of the growing dominance of this new genre of federal judges. During the Iggos, the "independence of the judiciary" became a rallying cry for several organizations, articulating concerns about the need to protect judges from popular and political attack. ${ }^{16}$ The development by Article III judges and Congress of a judicial corps appointed by life-tenured judges may provide an under-explored alternative in the election/appointment debate. This mode of judicial selection enhances opportunities for less politicized individuals to work as judges, free from forces other than the life-tenured judges to whom they are beholden for reappointment. But by enabling expansion of the federal judiciary through non-life-tenured judges, Article III judges may have demonstrated to Congress that less expensive judges (increasingly fungible with their more expensive, life-tenured colleagues) suffice, thereby undercutting claims of the need to augment the ranks of the tenured.

Moreover, while life-tenured judges have supported the multiplication of judges, they have been less generous about sharing their cultural capital with their constitutionally less secure and politically less visible counterparts. Doctrine and practices would have to shift to provide greater visibility and stature to judges now responsible for hearing a large percentage of federal adjudicatory work, including much to which the government is a party.

As the focus shifts from the individual tasks of judging and the structural protections of that work to the development of the infrastructure and governance within Article III, additional problems emerge. While bureaucratic developments seem inevitable, if not desirable, the question is whether this constitutional judicial bureaucracy should behave differently from other federal agencies. On the empirical side, the judiciary has adopted certain goals (such as slow growth) that make it peculiar among bureaucracies, generally conceived as

16 The American Bar Association's Special Committee on Judicial Independence works with state and local bar associations to respond to criticism when judges render politically unpopular decisions; support is provided in part by the Open Society Institute. See David E. Rovella, $A B A$ Issues Guide to Defending Judges, NAT'L L.J., Sept. 14, 1998, at A7; see also American Judicature Society, Judicial Independence: An Introduction, 80 JUDICATURE 155 (1997) (detailing its program); Editorial, Promoting Judicial Independence, 80 JUDICATURE 152 (I997) (describing the work of the Judicature Society); An Independent Judiciary, i4 NAT'L JUD. C. ALUMNI MAG. 4, 515 (1999) (presenting a series of essays on Judicial Independence); Citizens for Independent Courts, Mission Statement (visited Nov. 13, 1999) <http://www.faircourts.org/mission> (stating the group's dedication to preserving "the integrity of the processes for judicial selection in the state and federal systems"). 
endlessly self-enlarging. On the normative side, the problem is whether judges should form what I term a "programmatic judiciary" - with a plan about whether Congress should create new federal causes of action, be they about legal liability for " $\mathrm{Y}_{2} \mathrm{~K}$ " failures or about civil rights for women who are victims of violence.

Does responding to twentieth-century needs for federal adjudication necessarily entail that judges become policymakers attempting to direct allocation of judicial resources? Does a robust conception of adjudicatory right-seeking inevitably succumb to the demands created by a high volume of claimants? I think not. Given a constitutional commitment to separated powers, the Article III judiciary, qua judiciary, should not offer advice - outside of and in advance of adjudication - on the reach and proper deployment of congressional authority to create or to repeal causes of action enforced in federal courts. One problem is authority: on whose behalf are positions taken? If the claim is that the Article III judiciary is representing all judges, that proposition has weakened over the decades. Early in the history of its organizational life, the federal judiciary was self-conscious about not "speaking for" other judges without polling them first. More recent practices, however, rely on the voting powers of members of the Judicial Conference, a body composed of twenty-seven judges, some of whom achieve membership by virtue of seniority and none of whom are bankruptcy or magistrate judges. And if the Judicial Conference claims to speak for the country as a whole or segments of the population, the source of its charter is not obvious.

Atop the questionable constitutional and political authority of an enclave of judges pursuing a jurisdictional vision on behalf of the federal judiciary, a second concern is that a programmatic stance runs risks for judicial legitimacy. Adjudication is, of course, filled with political judgments. But with the changing composition of the courts, those rulings can be revisited, and when pressed by the radical particularism of adjudication, reshaped. In contrast, once a judicial platform has been crafted, it has a potential not only to be broad but also to become entrenched, owned by all and none. Moreover, readers can compare decisions in adjudicated cases with the jurisdictional policies of the federal judiciary. When parallels emerge (such as a proposal by the Article III judiciary for limited federal jurisdiction and subsequent rulings holding unconstitutional certain congressional grants of jurisdiction), questions follow about the disinterestedness of those adjudications.

The historical and comparative discussions within this essay offer alternative possibilities of roles for judicial organizations. Suggestions that judges could have different ways of expressing themselves as members of a corporate entity come both from earlier practices of the federal judiciary and from choices made by state judiciaries, many of which share with the federal judiciary the sense of a daunting work- 
load but nevertheless do not respond with campaigns against access to their courts. The differences in the programs of state and federal judiciaries prompt revisiting the conventional, celebratory reading of Article III's protections of judicial independence. Without the obvious need to search for popular support, the governing board of life-tenured judges seems removed from desires of citizens or legislators to use justice as an expressive means of norm development. The very freedom bestowed by Article III may propel those anointed under it to ignore the importance of popular perceptions of judicial utility to a robust role for all judges in a constitutional democracy.

Appreciative of the vision and energy of a century of judicial transformations, I counsel revisiting the contemporary manifestations. Rather than act like another federal agency, the life-tenured judiciary should develop norms to reflect its specific institutional character as a branch of government charged with adjudication, lacking a majoritarian mandate, and without means of recall. After a century of invention, the suggestion here is for more. The federal judiciary might take on ambitions as bold for the new century as it achieved during the last. Instead of conforming to bureaucratic form, the judiciary could adopt a more cacophonous route, mimicking common law methods of decisionmaking so that its adjudicatory work could drive its bureaucratic functions, rather than permitting its bureaucratic postures to overwhelm its particular contribution and its constitutional raison d'être - adjudication.

\section{JUdicial TRansformations of the DaIly PRaCtices of JUDGING}

In I 9 I $_{5}$, some I $_{20}$ federal judges were dispersed across the United States with, for example, a single district judge sitting in Indiana, another in Maryland, and another in Massachusetts. ${ }^{17}$ Working on some 30,000 cases, ${ }^{18}$ these judges operated as solo players, with few shared practices. ${ }^{19}$ Federal judges generally ran their courtrooms according to

17 See, e.g., 220 F. v-vii (1915) (listing the district judges and their assignments).

18 See Data on U.S. Court of Appeals, Number of Judgeships and Appellate Filings, Selected Years, and U.S. District Courts, Number of Judgeships and Cases Filed, Selected Years, provided in September 1998 to the author by the AO [hereinafter 1998 AO Judgeships/Filing Data] (on file with the Harvard Law School Library). In 1910, 32 appellate judges and 92 district judges dealt with about 30,000 cases, 28,652 at the trial level and $\mathrm{r}, 448$ at the appellate level. See id.

19 While different procedures were used on the "law" side, in 1912 the Supreme Court promulgated uniform equity rules for the federal courts. See Jack B. Weinstein, The Ghost of Process Past: The Fiftieth Anniversary of the Federal Rules of Civil Procedure and Erie, 54 BROOK. L. REV. I, 8 (I g88). Court rules also governed admiralty, bankruptcy, and copyright. See EDWARD A. Purcell, Jr., Brandeis aNd the Progressive Constitution: ERIE, the Judicial POWER, ANI THE POLITICS OF THE FEDERAL COURTS IN TWENTIETH-CENTURY AMERICA (forthcoming 2000) [hereinafter PURCELL, BRANDEIS AND the PROGRESSIVE CONSTITUTION]. A 
the differing procedures of the states in which they sat. These judges had little means of talking with each other, let alone with other members of government. The Attorney General (a member of the Executive Branch) gave Congress reports on the docket of federal courts and asked Congress to meet the budgetary needs of the federal judiciary.20 As Chief Justice William Howard Taft put it, each judge had "to paddle his own canoe."21

But the beginnings of the twentieth century brought widespread interests in professionalization, nationalization, and reorganization. The American Bar Association (itself a fledgling organization) joined with some judges and legal academics on several projects of court reform. Their work took many forms, rendering Taft's canoe image obsolete. Of immediate relevance were the efforts to conform federal judges' daily practices through reliance on shared, nationwide rules of procedure. ${ }^{22}$ In 1934, Congress agreed, authorizing the federal judiciary to draft and promulgate such rules. ${ }^{23}$

The Federal Rules of Civil Procedure, issued in 1938 and in use (many times modified) today, became a means of transforming the modes of judging. But, as detailed below, rules alone rarely change behavior. Energetic and evangelistic judges, committed to revamping the attitudes and practices of their peers, championed their vision of judging, preached it, demonstrated it, and then convinced their colleagues to create "school[s] for judges" 24 to teach new means of doing justice.

few statutes also prescribed certain procedural forms; how frequently and consistently these shared procedural provisions were used throughout the country is difficult to know.

20 The Attorney General began to file reports in $187 \mathrm{I}$; the Department of Justice also provided a range of services to the judiciary, such as obtaining supplies, processing vouchers, and equipping offices. See PETER GrahaM FISH, The POLITICS OF FEDERAL JUdicial AdMINISTRATION 9I-95 (1973); David S. Clark, Adjudication to Administration: A Statistical Analysis of Federal District Courts in the Twentieth Century, 55 S. CAL. L. REV. 65, 97 (198I).

21 William Howard Taft, Possible and Needed Reforms in Administration of Justice in Federal Courts, 8 A.B.A. J. 601, 602 (1922).

22 See Stephen N. Subrin, How Equity Conquered Common Law: The Federal Rules of Civil Procedure in Historical Perspective, 135 U. PA. L. REV. 909, 975 (1987) (stressing how those rules, relying on equity precepts, emphasized judicial discretion). The tension between the ruledrafters aspirations for uniformity and discretion is discussed in Judith Resnik, Changing Practices, Changing Rules: Judicial and Congressional Rulemaking on Civil Juries, Civil Justice, and Civil Judging, 49 ALA. L. REV. 133, 200-03 (1997) [hereinafter Resnik, Changing Practices, Changing Rules].

23 See The Rules Enabling Act, Pub. L. No. 73-415, 48 Stat. 1064 (1934) (codified as amended at 28 U.S.C. $\$ 2072$ (1994)). Its legislative history and the role played by Taft are explored in a classic essay by Stephen B. Burbank. See Stephen B. Burbank, The Rules Enabling Act of 1934, I30 U. PA. L. REV. 1015, 1069-98 (1982); see also PURCELL, BRANDEIS AND THE PROGResSive CONSTITUTION, supra note 19, at 25-33.

24 Warren E. Burger, School for Judges, 33 F.R.D. I39 (1964). 


\section{A. Procedural Aspirations and Sources}

What was the content of the rules that this group of judges, academics, and lawyers crafted? The reformers thought they had a lot to fix, that the means of getting to justice, circa I930, were overly cumbersome, intricate, technical - and too reliant on juridical categorization of causes of action. To lower barriers to entry, the reformers crafted a trans-substantive set of procedures that provided the same governing regime regardless of the kind of lawsuit (contract, tort, patent, federal statutory right) or of the form of relief (damages or injunctions).

"Liberal rules of pleading and joinder" is a phrase often used to describe the 1938 rules. ${ }^{25}$ Easy access to court was one element (captured by the use of the word "liberal"). Another was to permit the bringing together of more parties and claims ("joinder") under one larger umbrella, called a lawsuit. In addition to easy entry and wider parameters, the Federal Rules also reshaped the course of lawsuits by adding a system of information exchange ("discovery") among parties in advance of trial. ${ }^{26}$

As an afterthought - just before the rules were finalized - the drafters included something else new, called a "pre-trial."27 They borrowed this practice from state judges working in Detroit who, in the I920S, were the first to require an official meeting between lawyers and judges right before jury trials started. ${ }^{28}$ William Mitchell, the chair of the federal ruledrafting committee, proposed doing the same in federal court. The archived papers of the ruledrafters reveal that Mitchell's co-drafters balked at part of his suggestion, specifically that

25 See, e.g., Subrin, supra note 22, at $96 \mathrm{I}-73$; see also Richard L. Marcus, The Revival of Fact Pleading Under the Federal Rules of Civil Procedure, 86 CoLUM. L. REV. 433, 437-40 (1986).

26 See generally Stephen N. Subrin, Fishing Expeditions Allowed: The Historical Background of the 1938 Federal Discovery Rules, 39 B.C. L. REv. 691 (1998).

27 The drafting project began in 1935. Charles Clark, then Dean of Yale Law School, was the reporter. A full first draft was circulated in 1936 to local working groups. See Papers of Charles Clark, Sterling Law Library, Yale University, Series IV: United States Supreme Court Advisory Committee on Rules for Civil Procedure: Preparatory Papers, Drafls, Reports, Correspondence, 1935-56 [hereinafter Clark Advisory Committee Papers], at Box 97, Folder 17. A rule on "pretrial" did not enter the discussion until William Mitchell proposed it during the fall of 1936. See id. at Box 100, Folder 23.

28 See Ira W. Jayne, Foreword - Pre-Trial Procedure, I6 OHIO ST. L.J. 160 (1956); see also HARRY D. NIMS, PRE-TRIAL 3-4 (1950). Other judges in Boston, Los Angeles, Cleveland, and New York also "previewed" trials. See RULES OF CIVIL PROCEDURE FOR THE DISTRICT COURTS OF THE UNITED STATES AND PROCEedings OF THE INSTITUTE ON FEDERAL RULES 38-39 (William W. Dawson ed., 1938) [hereinafter I938 RULES]. Although their process apparently overlapped in some fashion with what in England was termed "directions" given by judges to lawyers, the state judges who invented the process did so "without any reference to the English plan." Edson R. Sunderland, The Theory and Practice of Pre-Trial Procedure, 36 MICH. L. REV. 215,225 (1937). 
this new procedure be available only for jury trials. ${ }^{29}$ The drafters hoped to achieve their goal of simplifying procedure by abolishing distinctions between law (with its jury trials) and equity (with decisions made only by judges); they wanted a single, trans-substantive set of rules without many variations. The drafting committee instead authorized the use of pre-trials but left to trial judges the choice of deciding when, where, how, and if to use it at all.

A small but telling linguistic point provides a window into the 1938 conception of a pre-trial. Then, a hyphen sat between the prefix, "pre," and the word, "trial." The I930s hyphenated word reflected that the meeting was to talk about the shape of the coming trial. ${ }^{30}$ As one proponent pointed out: "pre-trial, perhaps, is a misnomer; it is rather a part of the actual trial." ${ }^{\text {pi }}$

Over the last sixty years, the word pre-trial lost its hyphen, the rule governing the process grew much longer, and judges devoted more of

29 See Letter from William Mitchell to Charles Clark (Nov. 6, 1936), in Clark Advisory Committee Papers, supra note 27, at Box 110 , Folder 51 . The text of the 1938 rules, as promulgated, read in relevant part:

Rule i6. Pre-Trial Procedure; Formulating Issues.

In any action, the court may in its discretion direct the attorneys for the parties to appear before it for a conference to consider

(I) The simplification of the issues;

(2) The necessity or desirability of amendments to the pleadings;

(3) The possibility of obtaining admissions of fact and of documents which will avoid unnecessary proof;

(4) The limitation of the number of expert witnesses;

(5) The advisability of a preliminary reference of issues to a master for findings to be used as evidence when the trial is to be by jury;

(6) Such other matters as may aid in the disposition of the action.

The court shall make an order which recites the action taken at the conference, the amendments allowed to the pleadings, and the agreements made by the parties as to any of the matters considered, and which limits the issues for trial to those not disposed of by admissions or agreements of counsel; and such order when entered controls the subsequent course of the action, unless modified at the trial to prevent manifest injustice. The court in its discretion may establish by rule a pre-trial calendar on which actions may be placed for consideration as above provided and may either confine the calendar to jury actions or to non-jury actions or extend it to all actions.

1938 RULES, supra note 28, at 37-38; see also David L. Shapiro, Federal Rule 16: $A$ Look at the Theory and Practice of Rulemaking, 137 U. PA. L. REV. I969, 1978-81 (1989) (describing the drafting).

30 For example, the 1938 ABA Committee on Pre-Trial Procedure described the pre-trial as a "preview," during which the court should narrow the issues, shorten and speed the trial hearings, and ascertain whether trial is needed. See 1938 ABA Pre-Trial Committee Report, 63 A.B.A. ANN. REP. 534, 534 (1938).

31 Hon. Bolitha J. Laws, Pre-Trial Clinic: Demonstrations, 4 F.R.D. 35, 56 (1944) [hereinafter Judicial Conference/ABA Pre-Trial Clinic] (describing the practice in the District of Columbia at a conference co-sponsored by the Committee for the Improvement of the Administration of Justice of the Conference of Senior Judges of the U.S. Courts and by the Section on Judicial Administration of the American Bar Association). 
their attention to working under its auspices. ${ }^{32}$ Today the unhyphenated "pretrial" is a stage unto itself, no longer a prelude to trial but rather assumed to be the way to end a case without trial. Today's rule brims with details about what judges are supposed to do, including establishing "early and continuing control," organizing discovery, "facilitating the settlement of the case," and referring parties in appropriate instances to "special procedures" (such as arbitration or mediation) "to assist in resolving the dispute." ${ }^{33}$ In the contemporary rule, we find the managerial judge, the settlement judge, the dealmaking judge, the judge promoting alternative dispute resolution, and thus the Los Angeles judge telling lawyers that to go to trial was to admit a failure of this (new) system.

\section{B. A Corporate Structure, Large Scale Litigation, and More Cases}

Describing the fact of change does not explain how such change came about. The crafting of national procedural rules was part of a larger effort at unification. ${ }^{34}$ During the 1920 and 1930s, many entities within the federal government, the judiciary included, were organizing. ${ }^{35}$ In 1922 , Congress charged a body of judges (eventually called the Judicial Conference of the United States) to make policy for the federal judiciary. ${ }^{36}$ In I939, responding to the judiciary's request,

32 See the 1983 and 1993 revisions, as well as the new title, to "Pretrial Conferences; Scheduling; Management," at FED. R. CIV. P. I6.

33 FED. R. CIV. P. 16(a)(5), r6(c)(9) (1993). Linguistic changes other than the hyphen illuminate evolving conceptions of "the judicial." In the 1983 revision of Rule 16 , mention was made of "extrajudicial" procedures to assist in resolving disputes. See Rule I6(c)(7) (amended in 1983). By 1993, those procedures had become a part of the judicial; under the revised FED. R. CIV. P. $\mathrm{I} 6(\mathrm{c})(9)$, judges may give consideration to "settlement and special procedures to assist in resolving the dispute when authorized by statute or local rule." See generally Judith Resnik, Many Doors? Closing Doors? Altemative Dispute Resolution and Adjudication, 10 OHIO ST. J. ON DISP. RESOL. 21 (I995) [hereinafter Resnik, Alternative Dispute Resolution and Adjudication].

34 The promulgation of the Federal Rules of Civil Procedure in 1938 was followed in 1946 by nationwide rules in federal courts for criminal cases, in 1968 by nationwide rules for appellate procedure, and in 1975, after many revisions, see John Ely, The Irrepressible Myth of Erie, 87 HARV. L. REV, 693, 693-94 (1974), by nationwide rules of evidence.

35 Efforts included creation in 1921 of the Bureau of the Budget, see LARRY BERMAN, THE OFFICE OF MANAGEMENT AND BUDGET AND THE PRESIDENCY, I92 I-I979, at 4 (1979), and federal building programs aimed at enhancing the federal presence across the country, see Public Buildings Act of 1926 , ch. 380 , $\$ \S_{1-5}, 44$ Stat. 630 ; see also LOIS CRAIG, THE FEDERAL PRESENCE: ARCHITECTURE, POLITICS AND SYMBOLS IN UNITED STATES GOVERNMENT BUILDING $277-409$ (1977) (describing projects in the 1920s and 1930s).

36 See Act of Sept. 14, I922, ch. 306, $\$ 2,42$ Stat. 837, 838 (creating a Conference of Senior Circuit Judges "to advise [the Chief Justice] as to the needs of [each] circuit and as to any matters in respect of which the administration of justice in the courts of the United States may be improved"). The structural organization was related to the increase in the numbers of federal judges; the 1922 bill also added more than 20 federal judgeships. In 1937, the Act was amended to include participation by the chief justice of the United States Court of Appeals for the District of Columbia. See Act of July 5,1937, ch. 427,50 Stat. 473 (codified at 28 U.S.C. $\$ 218$ (1940)). In 
Congress authorized an Administrative Office to collect data and to submit budgets for the federal courts: ${ }^{37}$ With these additions, the federal judiciary gained a means of conversing internally and a basis upon which to develop programmatic aspirations. Meanwhile, the size of the federal judiciary was growing. Between I9IO and I940, the number of judges nearly doubled, from 124 to 245 , and the caseload increased from about 30,000 to some 70,000 cases. $^{38}$

These fledgling organizational steps provide the background for a focus on the federal judiciary of the I950s. During that decade, the United States government filed a series of antitrust lawsuits in eighteen different district courts against electrical companies. The federal judiciary, by then a data-collecting body, saw these related cases as a major undertaking. ${ }^{39}$ The Judicial Conference convened a committee to consider what it termed a special docket problem, the "protracted" case. ${ }^{40}$

The complexity of these lawsuits was an artifact of activities of all three branches of the federal government and of changes in underlying economic and social transactions. Congress created federal regulatory regimes and located enforcement rights in federal courts; the executive branch initiated lawsuits under these statutes; and the judiciary's new rules and doctrines permitted ever more sprawling interconnections of

1948, the Conference of Senior Circuit Judges was renamed the Judicial Conference of the United States. See Act of June 25, I948, ch. 646, 62 Stat. 902 (codified at 28 U.S.C. $\$ 33$ I (I994)). For discussion of subsequent inclusion of district judges, see note 86 and accompanying text.

37 See Act of Aug. 7, I939, ch. 501, $\$ \$ 302,304(2), 53$ Stat. 1223, I 223 (codified as amended at 28 U.S.C. \$\$ 601-I2 (1994)). The reasons for this authorization are explored in Peter Graham Fish, Crises, Politics, and Federal Judicial Reform: The Administrative Office Act of 1939, $32 \mathrm{~J}$. POL. 599 (1970), which argues that struggles over status, including the failed court-packing effort of 1937 , prompted judicial interest in institutional reform and sponsorship of control over administration.

38 See 1998 AO Judgeships/Filing Data, supra note 18 . Further, again through reform efforts of individual judges and lawyers, between 1891 and 1925 , the federal courts shifted into a threetiered structure (trial court, appellate court, and Supreme Court) staffed by different sets of judges with distinct jurisdictional mandates. See FELIX FranKFurTer \& JAMES M. LANDIS, THE BuSINESS OF THE SUPREME COURT: A STUDY IN THE FEDERAL JUDICIAL SYSTEM IO3-45 (I928),

39 See Alfred P. Murrah, Background of the Seminar, in Proceedings of the Seminar on Protracted Cases for United States Judges, 23 F.R.D. 319, 386-87 (1959) [hereinafter 1958 Protracted Cases Seminar] ("[T]he judicial process was literally breaking down under the weight of these cases.").

40 The Committee, called the "Prettyman Committee" after its chair, E. Barrett Prettyman, concluded that such cases posed an "acute major problem in the current administration of justice." Committee to Study Procedure in Anti-Trust and Other Protracted Cases, Procedure in Anti-Trust and Other Protracted Cases, 13 F.R.D. 4I, 64 (195 I) [hereinafter Prettyman Report]. The term "protracted" remained in use through the 1960s; by the early 1970s, an ABA Handbook noted that a section about "complex cases" was formerly denominated "protracted litigation." AMERICAN BAR ASS'N, THE IMPROVEMENT IN THE ADMINISTRATION OF JUSTICE 83 (5th ed. 197 I) [hereinafter ABA, IMPROVEMENT]. 
facts and claims to be conceptualized as a "case."41 Meanwhile, technology enabled the world in which these statutes and rules functioned to link more people and events. Social interactions, legislative intervention, and procedural rules helped to alter the idea of what bundle of activities and persons constituted a "case." This reconception in turn required renewed rulemaking, to devise yet more procedures to handle claims of illegality about activities that spanned several years and were undertaken by an array of parties. ${ }^{42}$

After a series of meetings in the r950s, a special committee of judges proposed a plan to cope. The core recommendation was that judges needed to shift their role: "The judge assigned should at the earlier moment take actual control of the case and rigorously exercise such control throughout the proceedings in such case."43 Specifically, a judge (described as "iron-hearted" in demeanor ${ }^{44}$ ) was supposed to hold conferences to meet the lawyers and to organize and control pretrial proceedings. 45

41 The input by the judiciary was the work product of both lawyers and judges. Although judges dominate federal ruledrafting today, lawyers played a prominent role in drafting rules in earlier decades. See Stephen C. Yeazell, Judging Rules, Ruling Judges, 61 LAW \& CONTEMP. PROBS. 229, 238-39 (1998) [hereinafter Yeazell, Judging Rules, Ruling Judges]. Judicial development of the interpretation of Article III, again interacting with lawyering efforts, was another necessary building block. In the Ig60s, the Supreme Court read the word "case" in Article III to permit state claims to be appended onto federal lawsuits, thereby enlarging the scope of potential filings. See United Mine Workers v. Gibbs, 383 U.S. 715, 728-29 (1966); see also 28 U.S.C. 81367 (1994) (using the term "supplemental jurisdiction" to embrace both pendant and ancillary jurisdiction). Continued confusion about the breadth of federal jurisdiction is discussed in David L. Shapiro, Supplemental Jurisdiction: A Confession, an Avoidance, and a Proposal, 74 IND. L.J. 2 I I (1998).

42 The point here is not simply that the caseload was rising, which it was. See 1908 AO Judgeships/Filing Data, supra note 18 . The composition of the caseload was also changing; the cases filed involved larger numbers of parties and more issues. Terminology again provides insight into shifting perceptions of what transactions can appropriately be grouped together. The term "a litigation," such as the "tobacco litigation" or the "asbestos litigation," reflects the understanding that a series of cases is a single unit, as well as the cultural effects of procedural innovations in rules and statutes authorizing court-based processing of many litigants and claims together. See, for example, FED. R. CIV. P. 23 , revised in 1963 to widen its scope; and 28 U.S.C. \& 1407 (1994), the r 968 multi-district litigation statute permitting transfer across districts of similar cases to be handled as a single unit for pretrial purposes. See generally Judith Resnik, From "Cases" to "Litigation", 54 LAW \& CONTEMP. PROBS. 5 (199I) (discussing these forms of litigation, other means of aggregation, and their implications).

43 Resolutions Adopted at the Seminar on Protracted Cases, in 1958 Protracted Cases Seminar, supra note 39 , at 614-15.

44 This description was attributed to a 195 I speech by Judge Prettyman. See Judicial Conference Study Group on Procedure in Protracted Cases, Handbook of Recommended Procedures for the Trial of Protracted Cases, 25 F.R.D. 35 I, 384 (1960) [hereinafter Handbook for Protracted Cases].

45 See id. at 385 . The Handbook recommended using the first pre-trial conference to define issues beyond what was set forth in the pleadings and to authorize discovery only within "the bounds" of the issues so delineated. See id. at 386-87. The Handbook suggested that judges (I) require counsel to confer prior to bringing discovery disputes to the judge, see id. at 396 ; (2) con- 
The proposal - to get control of a case from the outset - entailed a new, and different, role for judges. As the Judicial Conference's I 960 Handbook for Protracted Cases explained: "Control of a case during the trial thereof is familiar to all trial judges. But here we speak of control of the case in its procedural aspects prior to trial as well as during the trial itself." 46 Further, this new role was to be a limited one, specially designed for a new problem, the "protracted case." Again, as explained by the Handbook for Protracted Cases: "Let it be emphasized this is not the ordinary litigation. Our subject is rare in number, the truly complicated, a few hundred amid the tens of thousands of cases on federal court calendars." 47 Reflecting this special charter, one judge would be assigned "for all purposes"48 to the protracted case. In contrast, in ordinary litigation, most federal courts then relied on a "master calendar" that assigned different judges to work on the various phases of the same lawsuit. ${ }^{49}$ In short, to respond to the perceived demands of the "protracted case," federal judges proposed reorganizing their routines so that in multi-judge courts, a single judge would be identified as in charge of a particular protracted case.

This interaction among procedural innovations crafted with one kind of problem in mind and then applied to other contexts helped to produce a shift in the judicial role. Recall that, in the I920s, state judges created pre-trials to provide a time for judges and lawyers to meet before jury trials began. This new procedure caught the attention of a few of the federal ruledrafters. Because they aspired to a trans-substantive framework, the drafters incorporated the charter for pre-trials in the 1938 Rules but did not limit its deployment to jury trials. Some members of the federal judiciary then became enthusiastic proponents of such pre-trial meetings; they joined in a Conference Committee on Pre-Trial Procedures. ${ }^{50}$ One source of their interest was

sider employing masters to supervise discovery if needed, see id. at 390-93; (3) establish a "tentative timetable" for the phases of the litigation, including scheduling motions and forecasting the time to trial, id. at $395 ;$ (4) "promote" stipulations of fact among parties, see id. at 397 ; (5) consider bifurcation of issues for trial, see id. at $403-04$; (6) organize and limit the presentation of proof at trial, see id. at 405-06; and (7) control the use of experts on and proof of "complicated scientific, technical and economic facts," $i d$. at 415-31.

46 Id. at 383.

47 Id. at 359 (preface by E. Barrett Prettyman, Chief Judge of the U.S. Court of Appeals for the District of Columbia).

48 Id. at $373,377,384$ (recommending that a case be assigned "to one judge for all purposes" to enable "his prompt assumption of control" and that "necessary adjustment[s] should be made in the normal case load of the assigned judge").

49 See Proceedings of the Seminar on Procedures for Effective Judicial Administration, Part II, Calendaring Systems, 29 F.R.D. 191, 227-79 (1962) [hereinafter Effective Judicial Administration] (providing the remarks of a few judges and a law professor discussing individual and master calendar systems).

50 The Committee, created in I940, worked for that decade and the following to encourage use of pre-trials. See Records of the Pre-Trial Committee, 1940-1955, Entry 7, Boxes 1-3, located in 
the possibility of using such innovations to document for Congress, from whom the judiciary sought funding, that judges were attempting to make court processing more efficient. ${ }^{51}$ Thereafter, in the r950s, federal judges thought the concept of a pre-trial useful to apply to what was then a new context, protracted cases. ${ }^{52}$ Judicial adjustment of yet other rules - on calendars - enabled the pre-trial rule to be used by a single judge assigned to organize a large-scale case from start to finish. ${ }^{53}$

Record Group (RG) Ir6, National Archives, Washington, D.C. [hereinafter Pre-Trial Committee Records].

A word on archival sources and citation format is in order. Materials from the Senior Conference of Chief Justices (which then became the Judicial Conference of the United States) as well as documents from the AO, can be found at the National Archives in Washington, D.C. These materials are catalogued under Record Group (RG) I 16, Administrative Office of the U.S. Courts, and then by "entry" and the number of "containers" (or boxes). The collection includes documents from before and after the creation in 1922 of the Conference of Senior Circuit Judges through the mid-r 950 , as well as some items through the early I 960 s. Within each of the many file boxes are transcripts, memoranda, reports, notes, and correspondence, not always kept in a uniform manner. I will refer to the National Archive RG I 16 materials by the specific item title or description, followed by the title of the Entry, the box, and the file (when available). Documents from the following Entries are cited in this article, with short forms as shown:

Entry I: General Judicial District Administrative Files, 1899-1936, consisting of I4 boxes. Short form: General Administrative Files.

Entry 4: Records Related to Judicial Conference Meetings, I92 2-1958, consisting of 83 boxes. Short form: Judicial Conference Meetings Records.

Entry 5: Records Relating to Judicial Conference Committees, I94I-I957, consisting of 3 I boxes. Short form: Judicial Conference Committee Records.

Entry 7: Records of the Pre-Trial Committee, 1940-1955, consisting of 3 boxes. Short form: Pre-Trial Committee Records.

The General Counsel's Office of the AO also keeps historical materials, some of which overlap with those of the National Archives. The AO's set includes committee reports and some notes; the documents are stored in binders, by year, beginning in the mid-r 950 as and continuing to the present. Docurnents from this set are cited as JUDICIAL CONFERENCE RECORDS/AO COLLECTION.

51 See Letter from Henry P. Chandler, Director of the AO, to judges (Apr. 16, 1941) [hereinafter Chandler Letter of Apr. 16, 1941], in Pre-Trial Committee Records, supra note 50, at Box I, Folder Pre-Trial Committee (asking for responses to a survey about pre-trial usage and explaining that in a recent hearing, the subcommittee of the House Appropriations Committee "evinced lively interest in the procedure and would have welcomed a much more definite statement from men about its deployment).

52 See Report and Recommendations from the Pre-Trial Committee (Sept. 13, 1954), in PreTrial Committee Records, supra note 50, at Box 3, Folder Minutes (suggesting that the Judicial Conference create a committee, under the auspices of the Pre-Trial Committee, to study "the special problems in the pre-trial of long and complicated cases"). The Conference circulated that recommendation "throughout the Judiciary with a request for expression of the views of the judges." I 954 JUDICIAL CONFERENCE REPORT 24-25.

53 See 1954 JUDICIAL CONFERENCE REPORT, supra note 52, at 5 (proposing that Rule 16 be amended to specify that "[w]here protracted litigation of an action is probable," the action be assigned to a "designated judge" for trial and for "control of all matters preliminary to trial"). This suggestion was never made a part of the federal rules, but calendar systems changed to enable judicial management of cases. 
And the procedural migration did not stop there. In the I960s, worries about the size of court dockets grew, as did concerns that courts were insufficiently well-organized or business-like. ${ }^{54}$ In addition, lawyers learned how to use the discovery provisions created in the 1938 Rules and thereby expanded the range of activities undertaken before trial. Leaders of the federal judiciary took the mission of judicial control of the protracted case and expanded it from the large case to the smaller one. To do so, they reorganized their calendar procedures, generally dropping the master calendar and substituting the individual assignment system, so that every case - big or small was assigned to a specific judge, charged with managing it from start to finish. ${ }^{55}$

That individual calendar system also enabled administrators to count the number of cases each judge had, and to learn which judges "moved" cases faster and which judges disposed of cases more slowly. 56 By the I 980 s, the loosely structured mandate for pre-trial meetings

54 See Report of the Joint Committee for the Effective Administration of Justice, 1962 ANNUAL REPORTS OF THE ABA 314-17 (reporting on the court reform work of the committee of 14 legal organizations, including the $\mathrm{ABA}$, and chaired by Tom $\mathrm{C}$. Clark). The reference to business management runs the century, as illustrated by the choice of title - The Business of the Supreme Court: A Study in the Federal Judicial System - of Felix Frankfurter's and James Landis's 1928 book, in which the authors also call for "scientific" management and better information gathering. See FRANKFURTER \& LANDIS, supra note 38, at 248-54.

55 A committee, chaired by Judge John W. Murphy and charged with the task of formulating procedures for protracted cases, drafted a resolution proposing "techniques [that] will likewise save time, lighten calendars and further justice in most cases." Proceedings of the Seminar on Protracted Cases for U.S. Circuit and District Judges, 2 I F.R.D. 395, 52 I (1958) (hereinafter Protracted Cases for U.S. Circuit and District Judges]. At the suggestion of Judge James Alger Fee, another seminar devoted a day to the use of pre-trial procedure "in the ordinary civil action." Proceedings of the Seminar on Protracted Cases for U.S. Judges, 23 F.R.D. 319, 319 (1958). As Judge Fee put it, as "far as techniques are concerned, you are driving at the same end and obviously enough you go through the same motions." James Alger Fee, Similarity of Technigues in Ordinary Civil Cases and Protracted Cases, in Proceedings of the Seminar on Protracted Cases for U.S. Judges, supra, at 380,381 .

56 With the shift of judicial administration from the Attorney General's Office to the AO, see supra p. 942, efforts (still ongoing) were made to increase knowledge about the kind, form, and timing of dispositions. Over the decades, the focus on the rate of dispositions, by courts and by individual judges, has sharpened. For example, under the I990 Civil Justice Reform Act, Congress required a public report, "for each judicial officer," of the "number and names of cases that have not been terminated within three years after filing." 28 U.S.C. 8476 (a) (I994). RAND's evaluators of the Civil Justice Reform Act concluded that while the number of all cases pending had risen since the public reporting requirement was put into place, the number of cases pending more than three years had "dropped by about 25 percent." RAND JUDICIAL CASE MANAGEMENT EVAlUATION, supra note 1 , at xxx. The shift to individual calendars and increased data collection have thus enabled evaluations of judges in terms of the pace of dispositions. In contrast, data are not kept on the numbers of opinions written by trial judges. 
was rewritten, ${ }^{57}$ and judicial case management became codified as a part of the pretrial process and as a facet of judging. ${ }^{58}$

\section{Teaching Judges}

Writing rules and handbooks and altering assignment procedures do not necessarily change behavior. ${ }^{59}$ Not all judges - even in protracted cases - were shifting towards management. In response, the federal judiciary took on a new task: teaching. While this aspect of federal judicial work is rarely discussed in academic literature about the federal courts, ${ }^{60}$ the federal judiciary has become an educational institution, training judges about what "good judging" means.

The idea of educating judges is unremarkable today. Mid-century, however, proposing a school for judges in the United States ${ }^{61}$ was both novel and contested. In the words of a 1963 report from a consortium

57 See Judith Resnik, Managerial Judges, 96 HARV. L. REV. 374, 379 (1982) (discussing thenpending revisions to FED. R. CIV. P. I6).

58 A global footnote is also in order. The term "case management" is itself migrating, and can now be found in discussions of judging in England, Australia, and Canada. Judicial reformers are there arguing (with varying success and with a wide range of interpretations) the utility of judicial control of the litigation process. See ACCESS TO JUSTICE: FINAL REPORT TO THE LORD CHANCELLOR ON THE CIVIL JUSTICE SYSTEM IN ENGLAND AND WALES 13-16 (1996) (also known as "Lord Woolf's Report," after the committee's chair, Lord Harry Woolf, Master of the Rolls and presiding judge in the Court of Appeals, Civil Division). Commentary on that report can be found in Reform of CIVIL PROCEDURE: Essays on ACCess to JUSTICE (A.A.S. Zuckerman \& Ross Cranston eds., 1995). For discussion of such efforts in Australia, see G.L. Davies, The Changing Face of Litigation, 6 J. JUD. ADMIN. 179 (1996), in which Davies proposes that judges shift their role and oversee processes focused more on dispute resolution; and Issue Paper 20: Review of the Adversarial System of Litigation: Rethinking the Federal Civil Litigation System (Australian Law Reform Commission, Apr. 1997), which describes the governmentcommissioned inquiry and considers managerial judging, alternative dispute resolution, and other reforms. An example of Canadian interest in case management can be found in CANADIAN BAR ASS'N, SYSTEMS OF CIVIL JUSTICE TASK FORCE REPORT 34-38 (I996).

59 See generally Resnik, Changing Practices, Changing Rules, supra note 22, at $136-52$ (discussing how the use of juries smaller than twelve predated the rule authorizing such juries in federal courts).

60 Several books by legal academics consider the federal courts, but none delves into the interactions among doctrinal developments, rulemaking, institutional structure, the invention or effects of judicial education, adjudication, and the role of the federal courts. See, e.g., ERWIN CHEMERINSKY, FEDERAL JURISDICTION (3d ed. 1999); RICHARD A. POSNER, THE FEDERAL CoURTS: ChALlenge AND REForm (1996) (revising RICHARD A. POSNER, THE FEDERAL CoURTS: CRISIS AND REFORM (1986)); LARRY W. YACKLE, RECLAIMING THE FEDERAL COURTS (1994).

Two extensive and insightful discussions of the federal courts from other parts of the academy are attentive to institutional structure but also do not focus on the use of judicial education to alter conceptions of the judicial or on the relationship between the innovations of the Federal Rules and the invention of judicial education. See Wolf HeYdebrand \& Carroll SERon, RATIONALIZING JUSTICE: THE POLITICAL ECONOMY OF FEDERAL DisTRICT COURTS (I990); see also FISH, THE: POLITICS OF FEDERAL JUDICIAL ADMINISTRATION, supra note 20.

61 European justice systems, in contrast, characteristically provide formal training for judicial officers. See RUDOLF B. SCHLESINGER, COMPARATIVE LAW 154, 183-85 (4th ed. 1980). 
of more than a dozen prominent legal organizations promoting judicial reform, "the use of the word 'education' in connection with the judiciary brought raised eyebrows." 62 But a shift was occurring nationwide. On the state side, reformers believed that judges, particularly those in traffic and family courts, needed professional training. ${ }^{63}$ In the federal courts (assumed to be populated by already distinguished professionals $^{64}$ ), the focus was on teaching different ways of being a judge. ${ }^{65}$

Classes were not the first method by which the judiciary's Committee on Pre-Trial Procedure tried to change judicial behavior. In the I940s and I950s, the Committee distributed promotional surveys, asking judges to discuss their use of pre-trials. ${ }^{66}$ Learning of erratic use of and ambivalence about pre-trial processes, the Committee circulated pamphlets detailing how to conduct pre-trials; ${ }^{67}$ it also helped

62 Report of the Joint Committee for the Effective Administration of Justice, 1963 ANNUAL MEETING OF THE ABA 625,625 (noting that this attitude was being replaced by "genuine enthusiasm for more knowledge").

63 In the 1940 , in conjunction with a department of Northwestern University, the ABA started training judges in an effort to improve traffic courts. Parallel efforts were made in the

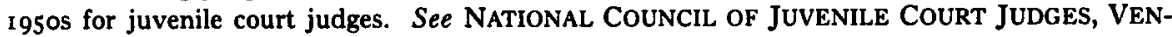
TURES IN JUDICIAL EDUCATION 24-25 (1967).

In 1960, the Kellogg Foundation funded a pilot "school for judges." In I963, the project became a permanent institution, called the National Judicial College, supported by a grant from the Fleischman Foundation and located in Reno, Nevada. See Robert Payant, Ethical Training in the Profession: The Special Challenge of the Judiciary, 58 LAW \& CONTEMP. PROBS. $3^{1} 3$ (I996); Frank J. Murray, Trial Judges' College Influence Major Factor for Next Generation, I TRIAL 35 (Aug./Sept. 1965) (describing the author's experience as a judge-student in the classes).

64. See notes 163-168 and accompanying text for discussion of the federal judiciary's selfconception as the most important judicial body in the country.

65 While having a different focus, federal judicial education efforts are related to parallel projects oriented towards state judicial reform. For example, that the first seminar for federal judges on protracted cases occurred at NYU Law School reflects the interest of that law school's dean (and later New Jersey's Chief Justice), Arthur Vanderbilt; he sought to reform judicial administration and promote an interaction between the legal academy and judges. See FANNIE J. KLEIN,

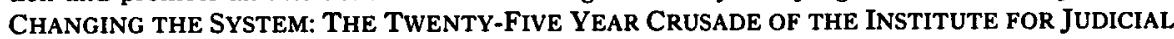
ADMINISTRATION FOR EQUAL JUSTICE IN AMERICAN COURTS, AN HISTORICAL PERSPECTIVE 25 (1977). In I952, Vanderbilt founded the Institute for Judicial Administration (IJA) at NYU to serve as a clearinghouse on judicial administration and to publish reports on the organization of courts and caseloads. In 1956, the IJA began an appellate judges seminar (which continues today), with sessions for new and experienced judges.

66 See Chandler Letter of Apr. 16, I94I, supra note 51 (describing the desirability of securing "fuller information concerning the use of the pre-trial procedure" and attaching a questionnaire to be answered individually by each district judge); Survey (Apr. 7, 1944), in Pre-Trial Committee Records, supra note 50, at Box 2, Folder Survey and Statistics, Federal Courts, 1944 (survey of April 7, 1944, discussed in a letter from Pre-Trial Committee to All District and Circuit Judges Concerning Pre-Trial Procedure in the Federal Courts); draft letter from the Chair of the Pre-Trial Committee, in Pre-Trial Committee Records, supra note 50, at Box 2, Folder Judicial Conference Pre-Trial Correspondence, 1946-48 (referring to collection of data about cases disposed of by June 30, 1949).

67 See Letter from Henry P. Chandler, Director of the AO, to all circuit and district judges (June 5, 194I), in Pre-Trial Committee Records, supra note 50, at BoX I (enclosing copies of discussions by judges on how to use the pre-trial); see also I94I JUDICIAL CONFERENCE REPORT 2; 
form circuit-based pre-trial committees to hold meetings at annual circuit conferences and to gather information about and discuss the use of pre-trials. ${ }^{68}$

The national Pre-Trial Committee also focused on the growing numbers of newly appointed judges; the Committee sent a special "warm welcome" letter to each judge and explained the utility of the pre-trial. ${ }^{69}$ In addition, Committee members offered to sit with any judge willing to take hands-on advice, ${ }^{70}$ and they provided materials for an article published in 1948 in Readers' Digest. ${ }^{71}$ As minutes from a meeting in I954 described, the Committee viewed its "most important work" as ensuring that "each of these new judges becomes an early convert to pre-trial."72

In 1954, when a member of the Judiciary's Administrative Office suggested the more formal route of an educational program to be held in Washington for new judges, he also described a colleague's response

Notes, in Pre-Trial Committee Records, supra note 50, at Box 2, Folder 1952 (notes from the ABA Commission on Pretrial Procedure of the Section on Judicial Administration, to which several members of the Judicial Conference's Committee on Pre-Trial belonged; describing the receipt of funds from the Carnegie Foundation to buy and distribute 2000 copies of Harry D. Nims's book, PRE-TRIAL; and discussing efforts to obtain academic attention to and writing about the practice); Pamphlet, in Pre-Trial Committee Records, supra note 50, at Box 2, Folder Pre-Trial Study, DC (pamphlet on pre-trial for distribution to new judges).

68 See Letter from Will Shafroth of the AO to Judge Alfred P. Murrah, chair of the committee (Dec. 7, 1948), in Pre-Trial Committee Records, supra note 50, at Box 2 (suggesting that Murrah write to each senior circuit judge to appoint circuit-based committees); Report of the Committee on Pre-Trial Procedure to the Chief Justice of the United States, Chairman, and Members of the Judicial Conference of the United States (Sept. 13, 1954), in Pre-Trial Committee Records, supra note 50, at Box 3, Folder Minutes (1954). In the September 13, 1954 report, the Committee recommended "that there be appointed or reconstituted by the chief judge of each circuit of the United States a pre-trial committee in each circuit." This recommendation was approved. See I954 JUDICIAL CONFERENCE REPORT, supra note 52, at 23-24.

69 One such letter begins:

The National Judicial Conference Committee on Pre-Trial Procedure bids you a warm welcome to the federal judiciary. . . . Many of our fine trial judges are convinced by experience that the sensible use of pre-trial as contemplated by the Federal Rules of Civil Procedure is of material aid in the proficient and expeditious disposition of litigation.

Letter from Alfred P. Murrah to Lester L. Cecil (May 25, 1953) (on file with the Harvard Law School Library). Judge Cecil was a newly appointed district judge in Ohio. See id.

$70 \mathrm{See}$ id. ('The National Conference has made provisions for new judges to sit on assignment with judges who regularly and effectively use pre-trial in comparable jurisdictions of your Circuit ... to allow them to observe first-hand the practical results to be obtained by its efficient use.").

71 See Frederic Sondern, Jr., Uncle Sam Modemizes His Justice, READERS' DIG., Aug. 1948, at 45 ("Tucked away at the end of a comparatively quiet corridor in the busy, noisy courthouse of the District of Columbia is one of the country's new and unusual tribunals - the Pre-Trial and Assignments Court. ... [It] dispenses more justice in less time than any other in the building."). Discussion of the Sondern article, as well as the article itself, can also be found in Pre-Trial Committee Records, cited above in note 50, at Box 2, Folder Pre-Trial Comm. 1949.

72 Agenda of July 15th meeting 2, in Pre-Trial Committee Records, supra note 50, at Box 2, Folder 1954. 
that "the idea of a 'school for judges' would lend itself to ridicule."73 Three years later, the Judicial Conference convened its first national seminars, not for new judges but for judges working on protracted cases. $^{74}$ In I 960 , the Judicial Conference of the United States began holding classes for new judges; while the curriculum spanned the docket, one focus of discussion was shifting behaviors during the pretrial phase of civil litigation. ${ }^{75}$ As the New York Times put it in 1965:

73 Letter from Will Shafroth to Alfred P. Murrah (Mar. 22, 1954), in Judicial Conference Commiltee Records, supra note 50, at Box 9, Folder Pre-trial Committee. By then, meetings that could be understood to have been "classes" had already occurred. See, e.g., Judicial Conference/ABA Pre-Trial Clinic, supra note 3I, at 35-36 (describing a session held with lawyers and judges at the Seventh Circuit's courthouse in Chicago in 1944 and sponsored by the Committee for the Improvement of the Administration of Justice of the Judicial Conference of Senior Judges and the Section of Judicial Administration of the American Bar Association); Letter to Will Shafroth (Dec. 9, 1948), in Pre-Trial Committee Records, supra note 50, at Box 3, Folder Correspondence (describing demonstrations of pre-trial procedure to a "packed courtroom of judges and lawyers" in Oklahoma on November 18,1948 ).

74 See Alfred P. Murrah, Foreword to Protracted Cases for U.S. Circuit and District Judges, supra note 55, at 395, 395-96 (1958). A few seats were "filled by judges recently appointed to the federal bench . . . in districts where potentially protracted cases were pending." Id.; see also Resolution of the Judicial Conference of the United States, in Effective Judicial Administration, supra note 49, at 192 (authorizing the Committee on Pre-trial Procedure, "in cooperation with the Committee on Court Administration," to conduct such meetings or seminars and to conduct a "special study for the purpose of developing a statement of the essentials of pretrial and trial practice for presentation to the Judicial Conference for its consideration and adoption").

The first program, "Seminar on Protracted Cases for U.S. Circuit and District Judges," was held at NYU Law School in 1957; seminars at other law schools followed thereafter. See Alfred P. Murrah, Foreword to Protracted Cases for U.S. Circuit and District Judges, supra note 55, at 395-96; 1958 Protracted Cases Seminar, supra note 39; see also E. Barrett Prettyman, Preface to Handbook for Protracted Cases, supre note 44, at 359-60 (describing a third seminar, held in 1959, at the University of Colorado); Handbook for Protracted Cases, supra note 44, at 373 n.I (same). A fourth, related seminar, On Procedures for Effective Judicial Administration, was held at Southern Methodist University in 1961. See Effective Judicial Administration, supra note 49, at I9I.

Judge Murrah reported the success of the first program - "the first time that a group of this size composed of federal judges has met together for a seminar to study a particular type of problem in the administration of justice" - to his colleagues on the Judicial Conference. PreTrial Procedure Report I I (Sept. 15, 1957), in JUdicial CoNFERENCE Records/AO CollecTION, supra note 50, at Binder Sept. 1957, Item 13.

75 For a request from the Judicial Conference for authority to run such sessions, see Report of the Pre-Trial Committee, Sept. I962, in JUdicial ConfERENCE RECORDS/AO ColleCtion, supra note 50, at Binder I. See also I962 JUDICIAL CONFERENCE REPORT 77 (authorizing the Committee to "conduct an annual seminar, commencing in 1963 , for recently appointed district judges"). For descriptions of topics discussed at such classes, see Alfred P. Murrah, Foreword to Reports of the Conference for District Court Judges, 59 F.R.D. 203, 205 (1973) [hereinafter 1973 Foreword]; and Proceedings of Seminar for Newly-Appointed District Judges, 75 F.R.D. 89 (I976).

Federal judicial education has now become routine; mandates for it appear as a means of implementing new rule regimes. See, e.g., The Civil Justice Reform Act of 1990,28 U.S.C. $\$ 480$ (I994) (requiring that the FJC and the AO "develop and conduct comprehensive education and training programs to ensure that all judicial officers . . . are thoroughly familiar with the most recent available information and analyses about litigation management and other techniques for reducing cost and expediting the resolution of civil litigation"). 
"The Federal judicial hierarchy is pushing a campaign to make its trial judges abandon their traditional role as passive umpires between opposing lawyers and to become more masterful in controlling trials."76 The newspaper caught the import of the efforts it reported; within the programs of these initial schools-for-judges can be found the beginnings of a self-conscious struggle about the role and posture of a federal trial judge.

On one side of the conflict were judges and lawyers who saw the pre-trial as an event designed to organize a trial; they rejected its use as an occasion for judges to promote settlement, ${ }^{77}$ and some were skeptical about it altogether. ${ }^{78}$ Other judges disagreed, arguing that judges at pre-trial conferences should attempt to dispose of cases without trial. ${ }^{79}$ As late as $197 \mathrm{I}$, an ABA handbook discussing pretrial pro-

Similarly, judicial education has blossomed nationwide. The activity is a multi-million dollar enterprise of conferences, educational materials, and meetings. See generally Judicial Education Reference, Information, and Technical Transfer Project (JERITT) (visited Nov. 29, 1999) <http://jeritt.msu.edu/futures.htm> [hereinafter JERITT] (reporting about a "National Symposium on the Future of Judicial Branch Education" in the fall of 1999 , sponsored by eight organizations - including the National Center for State Courts, the ABA and the National Judicial College - and aided by support from the State Justice Institute). JERITT is a clearinghouse for information about judicial education.

76 More U.S. Judges Going to School, N.Y. TIMES, June 23, 1965, at 13

77 Relying on his former role as the reporter for the committee that drafted the 1938 Rules, Judge Clark argued that Rule 16, "in its inception and in its wording, makes it clear that pre-trial is not intended as a substitute for trial; its whole tenor is that of proper preparation for trial." Charles E. Clark, To an Understanding Use of Pre-trial, in Effective Judicial Administration, supra note 49, at 454, 455-58; see Charles E. Clark, Objectives of Pre-Trial Procedure, 17 OHIO ST. L.J. 163,165 (1956) (arguing that the judge who was to preside at the trial should also preside at the pre-trial, and that the two events should be scheduled so as to be close together); Letter from Fred M. Raymond, District Judge (W.D. Mich.) to the Hon. John Parker (Apr. 28, 1944), in PreTrial Committee Records, supra note 50, at Box I, Folder Survey Federal Courts, 1944 (describing the "drastic criticism of pre-trial conference in which the judge is alleged to have endeavored to force settlement"); see also 1953 Recommendations to the Judicial Conference 6, in Pre-Trial Committee Records, supra note 50, at Box 2, Folder Committee on Pre-Trial (describing concerns raised in surveys that "pressure for settlement by the judge was bitterly resented," but noting that "[s]uch pressure in the federal courts is rarely, if ever, employed").

A review of Clark's archived papers reveals that in late 1936 and early 1937, drafts of what became Rule 16 did include references to settlement as one of the topics for discussion in a rule 16 pre-trial, but on a handmarked copy, this aspect of the proposed rule is crossed out. Clark Advisory Committee Papers, supra note 27, Box 100, Vol. VII (Dec. 1936-Jan. 1937), Vol. VIII (Feb. 1937).

78 See Statement of Paul McCormick (S.D. Cal.), attached to Report of the Committee on Pretrial Procedure to the Chief Justice of the United States, Chairmen, and Members of the Judicial Conference (1950), in Pre-Trial Committee Records, supra note 50, at Box 2, Folder 2 (Pre-Trial Comm. 1950), pp. 6-7 (discussing the "responsible resistance against pre-trial procedure" about which the Committee had learned, and raising the concern that the Committee's report did not "appear to in any substantial degree discuss such opposition to pre-trial procedure").

79 See, e.g., ro38 ABA Pre-Trial Committee Report, supra note 30, at 537-39 (discussing the use of pre-trials to avoid unnecessary trials by facilitating settlements); Bolitha J. Laws, Pre-Trial Procedure, Address Before the Section of Judicial Administration of the American Bar Association at Philadelphia, Pennsylvania (Sept. 10, 1940), in I F.R.D. 397, 401-02 (1940) (speaking at an ABA 
cesses stated that the "more common view [was] that the pretrial conference is not properly a device" for settlement (although settlement could be a by-product). ${ }^{80}$

But the faculty at the federal judiciary's seminars for judges took a different tack. In their lectures, these teacher-judges acknowledged that using pre-trials as settlement devices was controversial. Several of the members of the judicial faculty, however, were the same judges who had worked on the Handbook for Protracted Cases and on the Pre-Trial Committee. These teachers favored and taught active judicial involvement in settling cases. ${ }^{81}$ Over time, the advocates of case management became more assured, ${ }^{82}$ and the self-described evangelists won. ${ }^{83}$ By 1976 , in one of the lectures, a judge instructed that "most

conference and explaining his settlement efforts, including reassuring counsel that his views should not deter them from seeking their day in court); see also Resnik, Changing Practices, Changing Rules, supra note 22, at 160-64, 174-78 (providing additional details of this debate).

80 ABA, IMPROVEMENT, supra note 40 , at 78 . The language tracks reports of the Committee on Pre-Trial of the Judicial Conference. See Pre-Trial Committee Records, supra note 50, at Box 2, Folder Pre-Trial Comm. 1949 (including a 1944 report of the committee noting that "[ $t$ ]he Committee considers settlement as a by-product of a good pre-trial procedure rather than as a primary objective to be actively pursued by the judge" and that a judge should content himself with "opening the mind of counsel to the possibility of settlement rather than actively attempting to settle the case himself").

81 See, e.g., Edward S. Northrop, Role of the Judge in the Settlement Process, Lecture at Round Table 12 of the Seminar for Newly Appointed U.S. District Court Judges (Mar. 27-Apr. 3, 1971) (copy available at the Harvard Law School Library); see also Peter Fay, Settlement Approaches, in SEMINARS FOR NEWLY APPOINTED UNITED STATES DISTRICT JUDGES 67 (1973); Noel P. Fox, Settlement: Helping the Lawyers to Fulfill their Responsibility, in SEMINAR FOR NEWLy APPoINTED UNITED STATeS DisTrict JUdGES I (1972) [hereinafter Fox, Settlement]. West Publishing Company published materials from some of the early seminars in free-standing volumes. See 1973 Foreword, supra note 75, at 205. Materials can also be found in the library of the Federal Judicial Center, Thurgood Marshall Building, Washington, D.C.

82 See, e.g., Walter E. Craig \& Dean Gordon A. Christenson, The Settlement Process, Report of Seminar F, in Reports of the Conference for District Judges, supra note 8I, at 253-54 (describing the "richness and variety of judge's skills in the settlement role" and the "creative ingenuity to generate new techniques rapidly," such as ex parte meetings with counsel and sealed estimates on recommendations of sums, and noting that the judge was moving from running a "traditional pretrial conference" toward a process "of mediation"); Hubert L. Will, Robert R. Merhige, Jr. \& Alvin B. Rubin, The Role of the Judge in the Settlement Process, in Proceedings of Seminar for Newly Appointed United States District Judges, 75 F.R.D. 89, 203, 227-32 (1976) (providing examples to newly appointed judges in 1976 about how to mediate cases and evaluate their worth, with headings such as "The Beginning Moves," "The Atmosphere," and "Tactics"); see also Fox, Settlement, supra note 81, at 145, 146-55 (advocating judicial promotion of settlement as "an ultimate use" of pretrial).

83 According to one such advocate:

[W] plead guilty of utilizing the next few days to proselytize .... [M]ost of the techniques to be discussed here will also prove helpful to all judges, regardless of whether they are converted to our belief in early judicial intervention.

Irving R. Kaufman, The Philosophy of Effective Judicial Supervision over Litigation, reprinted in Effective Judicial Administration, supra note 49, at 207, 207. Sondern described Judge Bolitha Laws, returning from his investigation of state use of pre-trial procedures, as a "crusader," and noted that "[e]ver since [Laws's return], he and a group of the nation's foremost judges and attor- 
cases ... are better disposed of, in terms of highest quality of justice, by a freely negotiated - settlement, than by the most beautiful trial that you can preside over."84

Let me clarify the point. Throughout the century, some judges and lawyers surely met with each other and talked about settling cases. Settlement was - and is - always on the table. My interest here is not in informal discussions among judges and lawyers but in official mandates for federal judges and in conceptions of the judicial role. The shift I have traced begins in the I920s, runs through rulemaking in the r930s, protracted litigation in the r950s, and schools for judges in the following decades, and finds current expression in the comments of a federal judge explaining in 1994 to lawyers at a federal bar meeting in Los Angeles that going to trial meant that "the system" had failed.

\section{AN INSTITUTIONAL VOICE}

The issue with which I began was the alteration of the role of judging, with a focus on how judges handle their cases. Interconnected with that change - and a necessary part of it - was the transformation of the federal judiciary itself, such that it could be said to have a point of view, to have substantive conceptions of the judicial role other than making rulings in individual cases. A second purpose of this essay is to understand the relatively recent construction of the corporate identity of the federal judiciary.

During the course of the twentieth century, the federal courts became an agency, by which I mean an entity that not only organizes itself but also represents - and in practice defines - a set of interests. Below, I outline the origins and components of the federal judicial agenda and explain how the federal judiciary functions as an interest group. The media often depict judges working on the bench, and academia debates their written opinions, but neither focuses much on how judges run their own organizations and how those organizations affect theories of adjudication and constitutional allocations of power.

\section{A. The Infrastructure}

As noted, Congress created the first governing body - the Confer-

neys have been preaching their gospel to bar associations all over the country." Sondern, supra note 71 .

84 Hubert L. Will, Judicial Responsibility for the Disposition of Litigation, in Proceedings of Seminar for Newly Appointed United States District Judges, supra note 82, at 117,123 . My focus is the trial courts; for discussion of means of avoiding decisionmaking at the appellate level, see Mitu Gulati \& C.M.A. McCauliff, On Not Making Law, 61 LAW \& CONTEMP. PROBS. I 57 (1998). For more on settlement efforts at the appellate level, see note 304 , below. 
ence of Senior Circuit Judges - for the federal judiciary in $1922 .{ }^{85}$ Today's version, called the Judicial Conference of the United States, consists of a council composed of twenty-seven, including the Chief Justice of the United States Supreme Court, the chief judges of each circuit and of the Court of International Trade, as well as district judges selected from each circuit by the district and appellate judges of each circuit. ${ }^{86}$ In 1939, at the suggestion of the Conference, Congress created the Administrative Office (AO) of the United States Courts to take the administration of the judiciary out of the executive's Department of Justice. ${ }^{87}$ Aided by the AO, the Conference makes official policy for the federal judiciary through a formal voting process and by means of committees, reports, and staff work. For example, Conference members decide the federal judicial position on pending legislation and whether to present testimony to Congress. ${ }^{88}$ In 1967, again at the suggestion of the Conference, Congress created the Federal Judicial Center (FJC), an entity within the judiciary specially focused on education and research. ${ }^{89}$

85 Seè supra note 36.

86 See 28 U.S.C. 8331 (1994). Although district judges were not initially members of the Conference, they were admitted after the statute was amended in 1957 to require that district judges, selected by both district and circuit judges from each of the circuits, serve for fixed terms. See Act of Aug. 28, 1957, Pub. L. No. 85-202, 7 I Stat. 476 (codified at 28 U.S.C. 833 (I994)).

87 See Act of Aug. 7, 1939, ch. 501, 8302,53 Stat. 1223,1223 (1939) (codified at 28 U.S.C. \$ 60I (I 994)); see also 28 U.S.C. 8605 (I994) (charging the AO's Director with submitting budget estimates for the federal courts to the Office of Management and Budget). Much of the governance of the judiciary has been centralized, but some aspects, including decentralized budgeting, make each district court an administrative unit as well. See Administrative Office of the U.S. Courts, A Guide to the Administrative Control of Funds in the Judiciary (I998 draft, on file with the Harvard Law School Library).

88 See 28 U.S.C. \& 33 I (1994) ("The Chief Justice shall submit to Congress an annual report of the proceedings of the Judicial Conference and its recommendations for legislation.").

89 See Act of Dec. 20, 1967, Pub. L. No. 90-2 I9, ch. 42, 8 620, 81 Stat. 664 (1 967); see also Russell R. Wheeler, Empirical Research and the Politics of Judicial Administration: Creating the Federal Judicial Center, 5 I LAW \& CONTEMP. PROBS. 3 I, 38-4I (I988) (discussing the political exchanges that enabled the creation of the Center). The overlap in functions between the $A O$ and the FJC has sometimes been a source of interoffice tensions. See GENERAL AccountING OFFICE, GAO/GGD-95-236BR, THE FEDERAL JUdiCIARY: OBSERVATIONS ON SELECTED IsSUES 3, 18-40 (1995) (finding overlapping functions but "little duplication of activities or services").

During the twentieth century, court-based personnel also formed their own organizations. One of the earliest was the National Organization of Court Clerks, begun in the I920s to press for a change in compensation from a fee-for-service system to a salary system. See National Org. of Court Clerks, Articles of Association (July 8, 1922), in General Administrative Files, supra note 50, at Box 2, Misc. Folder (stating the goal of establishing "uniformity of practice and procedure in the courts of the several Circuits and Districts") (adopted July 8, 1922 in Washington, D.C.). By the 1990s, several organizations of court administrators existed, working nationally and locally, including the National Association of Court Managers (NACM) and the Conference of State Court Administrators (COSCA); of educators, including the American Academy of Judicial Education (AAJE) and the National Association of State Judicial Educators (NASJE); and of court reporters. See JERITT, supra note 75 . 
The Supreme Court has a unique position within the judiciary; it functions independently, making its own rules and having a different budgeting process than that of the lower courts. ${ }^{90}$ The Chief Justice of the Supreme Court is the bridge figure, chairing the Judicial Conference as well as appointing members of committees. ${ }^{91}$

The kinds of personnel within the judicial branch have, like the entities within it, also increased. Instead of the three-tiered pyramid often used to depict the federal courts (with the Supreme Court, intermediate appellate courts, and trial courts), picture instead a four-tiered structure with several add-ons. The Supreme Court remains at the top with its nine Justices. Below, some 270 judges sit on thirteen appellate courts. $^{92}$ At the trial level, two tiers of federal judges now exist. About 850 constitutional judges (district judges with life tenure) ${ }^{93}$ are joined by roughly the same number of statutory judges (magistrate and bankruptcy judges, appointed by the life-tenured judges for fixed, re-

90 See Richard S. Arnold, Money, or the Relations of the Judicial Branch with the Other Two Branches, Legislative and Executive, 40 ST. LoUIS U. L.J. I9, 22 (1996) (describing Judge Arnold's work as chair of the Budget Committee of the Judicial Conference and noting that he was not a "representative of the Supreme Court - the Justices do that themselves"); Peter Owen, The Supreme Court Budget Process - A Threat to the Independence of the Judicial Branch? 4-7 (unpublished manuscript, on file with the Harvard Law School Library) (describing the Court as preparing its budget independent of the rest of the judiciary and the Justices' appearances before congressional subcommittees); see also ADMINISTRATIVE OFFICE OF THE U.S. COURTS, THE JUdiciarY: CONGRESSIONAL BUDGeT SUMMARY, FISCAL YEAR 1999, at 19 (1998); Harvey Rishikof \& Barbara A. Perry, "Separateness But Interdependence, Autonomy But Reciprocity": A First Look at Federal Judges' Appearances before Legislative Committees, 46 MERCER L. REV. 667,674 (1995) (discussing appearances by Justices before congressional committees to discuss budgets). Chief Justice William Howard Taft led the way in 1923; in 1943, the practice shifted from "periodic" appearances by Justices to "an annual event." Id. at 675 (also noting the development of the tradition of sending more junior or mid-level Justices to testify).

91 See 28 U.S.C. 8331 (1994). The Supreme Court also promulgates the rules governing lower court practices. See 28 U.S.C. $\$ \S 2071-2075$ (1994).

92 In 1997 , the 155 active appellate judges were joined by 87 senior appellate judges. See ADMINISTRATIVE OFFICE OF THE U.S. COURTS, JUdICIAL BUSINESS OF THE UNITED STATES COURTS: 1997 REPORT TO THE DIRECTOR at 33 tbl.12 (1997) [hereinafter I997 AO DIRECTOR'S REPORT]. In addition, 190 active district judges and 133 senior district judges sat by designation at specific times. See id. at 375 tbl.V-2; see also 28 U.S.C. $\$ 291$ (a) (1994) (authorizing circuit judges to sit on other circuits); 28 U.S.C. $\$ 292$ (a) (1994) (authorizing district court judges to sit on the courts of appeals). See generally Richard B. Saphire \& Michael E. Solimine, Diluting Justice on Appeals: An Examination of the Use of District Court Judges Sitting by Designation on the United States Courts of Appeals, 28 U. MICH. J.L. REFORM 35 I (1995).

Thus, the appellate courts should be understood as consisting of at least 266 appellate judges, assisted on occasion by 323 district judges. The boundaries of the appellate circuits are increasingly permeable, as judges sit by designation in other circuits and district court judges sit on appellate courts.

93 This number includes both active and senior status judges. See 1997 AO DIRECTOR'S REPORT, supra note 90, at 33 tbl.I2 (I997) (indicating 647 authorized judgeships, minus the 69 vacancies, plus the 278 senior judges). 
newable terms). ${ }^{94}$ The district courts themselves sit as appellate courts to review some of the work of magistrate and bankruptcy judges, as well as certain decisions of administrative law judges; some bankruptcy judges now also do appellate work, reviewing rulings of other bankruptcy judges. ${ }^{95}$

The statutory judges emerged in force beginning in the late rg6os and are now permanent fixtures, with ever-growing powers and caseloads. ${ }^{96}$ The physical embodiment of this shift in authority can be seen in new federal courthouse construction. Not only are magistrate judges' courtrooms built into the design, ${ }^{97}$ but their dimensions - like the powers of magistrate judges - have grown; the 1997 construction manual for federal courthouses requires that magistrate judges' courtrooms expand from 1500 to I 800 square feet. ${ }^{98}$

\footnotetext{
94 About 770 people are magistrate and bankruptcy judges. See id. at 34-35 tbls. I3 \& 14 (reporting that as of September 1997,326 bankruptcy positions were authorized, of which 313 were filled, with an additional 22 "recalled" judges serving that court; and reporting 432 full-time magistrate judges and 75 part-time magistrate judges - for a combined total of 767 full-time statutory judges); 28 U.S.C. $\$ 152$ (a) (1994) (providing for bankruptcy judges to be appointed for I4year terms by appellate judges of that circuit); 28 U.S.C. $\$ 631$ (e) (1994) (providing for magistrate judges to be appointed for eight-year terms by district courts).

95 See 28 U.S.C. \& I58(b), (c) (I993) (requiring, under specified circumstances, that judicial councils establish three-judge bankruptcy appellate panels (BAPs) in lieu of district judges to hear appeals).
}

96 For a chart detailing the increase in kinds and quantity of matters handled by magistrate judges through a comparison of their work in 1972, 1986, and 1994, see RICHARD H. FALLON, DANIEL J. MELTZER \& DAVID L. SHAPIRO, HART AND WECHSLER'S THE FEDERAL COURTS AND THE FEDERAL SYSTEM 52 (4th ed. 1996) [hereinafter HART \& WECHSLER].

In terms of caseload, bankruptcy judges have a larger docket than do other judges within Article III and do much of their work without review. In 1997, for example, 1,367,364 bankruptcy filings resulted in 1,158 bankruptcy appeals. See Administrative Office of the U.S. Courts, Judicial Business of the United States Courts, 77, 260 (tbls.B-1 \& F-2) (1997) <http://www. uscourts.gov/judicial_business/contents.htmls. Extrapolated, less than $0.1 \%$ of bankruptcy decisions received appellate court (as contrasted with district court) review.

97 See Heidi Landecker, Federal Architecture: A New Era, 85 ARCHITECTURE 64 app. at 7678 (Jan. 1996) (detailing many of the federal projects then under way and discussing courtrooms for different kinds of judges, such as the new building in Portland, Oregon, with 13 district and seven magistrate judge courtrooms; one in New York City with " 43 district and magistrate courtrooms"; one in Greenbelt, Maryland, with two courtrooms for each kind of judge, magistrate, bankruptcy, and district; and one in Tampa, Florida, with seven district, five magistrate, and five bankruptcy judge courtrooms).

Magistrate courtrooms have another use - providing justification to Congress of the need for more courtrooms (potentially to be used by any kind of judge). Courtroom space is a topic about which controversy has emerged, as some members of Congress propose reductions in the building programs and requirements that judges share courtrooms. See ADMINISTRATIVE OFFICE OF THE U.S. COURTS, REPORT TO CONGRESS ON THE OPTIMAL UTILIZATION OF JUDICIAL RESOURCES 27-33 (Jan. 1998) [hereinafter I998 OPTIMAL UTILIZATION]; GENERAL ACCOUNTING OFFICE, GAO/GGD-97-39, COURTROOM CONSTRUCTION: BETTER COURTROOM Use Data Could Enhance Facility PlanNing and Decisionmaking 4 (1997).

98 See U.S. CoURTS DESIGN GUIDE 4-4I (Dec. 19, I997). The Guide was prepared under the direction of the Security and Facilities Committee of the Judicial Conference of the United States, and is available from the U.S. Department of Commerce, Accession No. PB97-152466. This 
Other rooms within the courthouse merit discussion. The majority of space within new courthouses is devoted to offices for staff. ${ }^{99}$ In addition to clerical and administrative workers, a host of auxiliary personnel - bearing titles such as "court-annexed arbitrators," "early neutral evaluators," "mediators," "parajudicial officers," and "staff attorneys" - also work under the aegis of judges to provide advice to litigants and sometimes to make decisions about disputes. ${ }^{100}$

Focusing on the population of decisionmakers within the walls of federal courthouses, however, does not fully capture all the participants in federal adjudication. Many judges decide claims under federal law but work elsewhere in the federal government. Almost I400 judges are in federal agencies, such as the Social Security Administration (SSA), the Securities and Exchange Commission (SEC), and the Equal Employment Opportunity Commission (EEOC). ${ }^{101}$ Hearing of-

guide was first published in I991, see id. at Preface-2. For details of the prior space requirements, see the Guide at Revisions-3. Before the 1991 publication of this guide, the Judicial Conference had courtroom design requirements. See, e.g., I 984 JUDICIAL CONFERENCE REPORT 8 (discussing the circulation of guidelines to circuits for comments); I 986 JUDICIAL CONFERENCE REPORT 59 (describing the adoption of guidelines in 1984 ).

99 For example, in the new federal courthouse in Boston, courtrooms occupy under ro\% of the usable space. See Douglas P. Woodlock, Judicial Responsibility in Federal Courthouse Design Review: Intentions and Aspirations for Boston, in FEDERAL BUILDINGS, supra, at 55, 6I [hereinafter Woodlock, Judicial Responsibility]. Offices and public spaces (including corridors and entry ways) account for about $80 \%$ of the remaining space, with the rest devoted to non-public routes of circulation for judges, staff, and detainees. See Henry N. Cobb, Design of the Boston Federal Courthouse: The Architect's View, in FEDERAL BUILDINGS IN CONTEXT: THE ROLE OF DESIGN REview 77, 79 (J. Carter Brown ed., I995) [hereinafter FEDERAL BuILDINGS]. Some 40 judges (both resident and nonresident) and 1000 other employees work in the building.

100 How much to focus on these providers is an issue. The use of alternative dispute resolution (ADR) has been promoted through amendments to Rule 16, the Civil Justice Reform Act, and most recently, the Alternative Dispute Resolution Act. See supra note 3. Some commentators report, however, relatively infrequent use of ADR other than judge-run settlement conferences. See generally JAMES S. KAKALIK, TERENCE DUNWORTH, LAURAL A. HILL, DANIEL MCCAFFREY, MaRIaN OSHIRo, Nicholas M. PACE \& MARY E. VaIANA, AN EVAluation of MEdiaTION AND EARly NeUtRal EVAluation UNDER THE Civil JuStice REFoRM ACT (RAND, 1996). For efforts to increase use of and describe extant programs as significant, see ELIZABETH PLAPINGER \& DONNA STIENSTRA, ADR AND SETTlement IN THE FEderal Courts: A SOURCEBOOK FOR JUDGES AND LAWYERS 4-IO (I996) (provided as a joint project of the Federal Judicial Center and the CPR Institute for Dispute Resolution).

101 As of September 30, 1997, 1387 administrative law judges were assigned to federal agencies. See U.S. Office of Personnel Management, Federal Civilian Workforce Statistics, Occupations of Federal White-Collar and Blue-Collar Workers as of Sept. 30, 1997, at 97-98 tbl.W-E (1998) (copy on file with the Harvard Law School Library); Paul R. Verkuil, Reflections upon the Federal Administrative Judiciary, 39 UCLA L. REV. I34I, I343 (I992) (explaining that, as of the early I990s, about 1200 ALJs were "assigned to 30 agencies," and that the number of ALJs was then "approximately equivalent to the number of judges on the federal trial bench").

Measuring the workload volume of these judges is difficult given that the kinds of disputes, the number of parties, and the complexity of cases vary from agency to agency and from agency to court. Verkuil concluded that "ALJs probably decide more 'cases' each year than do their federal judicial counterparts." Id. For example, in the 1997-98 fiscal year, ALJs in the SSA handled 500,000 cases; the Appeals Council considered 101,000 appeals. See Social Security Administra- 
ficers, described by some as a "hidden judiciary"102 because they function outside the parameters of the Administrative Procedure Act, are yet another group of judges. The rooms in which the various administrative law judges work do not much resemble the picturesque courthouses of popular imagery, and, like the office buildings they occupy, the visibility of this group of federal adjudicators is low.

To summarize, over the last sixty years, the federal judiciary's ranks have swelled; it now consists of some 2000 judges and about 30,000 staff superintending an array of other judicial actors. The judiciary is supported by a budget of $\$ 3.95$ billion (representing about twotenths of one percent of the federal government's annual expenditures). ${ }^{103}$ From the vantage point of William Howard Taft's canoe, the federal judiciary has gained stunning organizational strength. By federal government standards, however, the federal judiciary remains a small, low-budget operation.

Turning from this structural description to questions of function, the managerial efforts undertaken by the federal judiciary as a corporate entity parallel the managerial efforts undertaken by individual judges to control their dockets. Inter-branch exchanges are an important part of the work; ${ }^{104}$ the staff of the judiciary's AO knows well its

tion, About SSA's Office of Hearings and Appeals (visited Jan. 7, 2000) <http://www. ssa.gov.oha/overview.htm>. In fiscal year 1998 , the EEOC received 12,218 requests for administrative hearings and resolved 7494 appeals. In addition, the EEOC receives about 75,000 charges annually; 48,000 discrimination charges are resolved through state and local programs. See United States Equal Employment Opportunity Commission, EEOC Enforcement Activities (visited Oct. 3, 1999) <http://www.eeoc.gov/enforce.html>.

102 Verkuil, supra note I0I, at 1345 . Some 2000 such judges, with titles such as presiding officers, administrative judges, hearing officers, or examiners, work with federal agencies but are not classified as ALJs under the Administrative Procedure Act. According to a I989 survey conducted by the Administrative Conference of the United States, these judges decided about 350,000 cases. The largest set of cases (about 152,000 ) was decided by immigration "administrative judges," employed by the Department of Justice; the Department of Health and Human Services relied on "presiding officers employed by insurance carriers . . . [to decide] 68,000 cases per year"; and the Department of Veterans Affairs handled 58,000 cases. Id. at 1346 . These judges employed "procedures that range from the equivalent of formal APA hearings to informal processes from which there is no appeal." Id. at 1347 .

A recent example of efforts to articulate standards and roles for these officers comes from proposed rulemaking by the Environmental Protection Agency to clarify procedures for "regional judicial officers" who handle "non-Administrative Procedure Act" cases. Consolidated Rules of Practice Governing the Administrative Assessment of Civil Penalties, 63 Fed. Reg. 9464 (I998) (to be codified at 40 C.F.R. pts. 22, 59).

103 See Finally, a Budgetl Year 2000 Brings COLA for Judges, THIRD BRANCH, Dec. I999, at I, 5 (noting that the "spending bill appropriates $\$ 3.95$ billion for the entire judicial branch in FY 2000" and summarizing the allocations for salaries, expenses, defender services, juror fees, and court security); Office of Management and Budget, Budget of the United States Government (1999) (projecting a total outlay of $1,785.0$ billion dollars for FY 2000).

104 See generally JUDGES AND LEgISLATORS: TOWARD INSTITUTIONAL COMITY (Robert A. Katzmann ed., I988); RoberT KaTzMANN, CourTS AND CONGRESS (1997); Rishikof \& Perry, supra note 90. 
counterparts on the Hill. ${ }^{105}$ Members of the AO staff and federal judges now regularly appear before Congress to testify on pending legislation. A good deal of energy is spent on the docket as a whole, its volume, and the flow of its dispositions. In addition to the education of judges and staff (increasingly addressing how to administer their courts and budgets ${ }^{106}$ ) and the collection of data, the federal judiciary as an entity now worries about federal judges' salaries, their cost of living increases, pensions, travel budgets, sharing courtrooms (as compared to having a courtroom of one's own), building and maintenance, staff and employment policies, and the nature of federal judges' assignments, that is, jurisdictional grants.

To continue the parallel between the development of a managerial judge and a managerial judiciary, over the past three decades the judiciary as a whole has attempted to heed the advice it gave in the r95os to judges handling protracted cases: "take control, early on."107 Hence, the volume of statements other than decisions in cases has increased in an effort to communicate to Congress the federal judiciary's attitudes about the work assigned to the federal courts and the judiciary's aspirations for the future. Beginning with the tenure of Warren Burger, Chief Justices of the Supreme Court have given speeches annually on the "state of the judiciary."108 In I99I, the judiciary created the Office of Judicial Impact Assessment to provide Congress "impact statements" about the anticipated effects (in practice, described mostly as

105 See Conversation with AO staff (Sept. 23, 1998). Some of the members of the AO came from the Hill, and judicial members of some of the Conference Committees are chosen because of their relationships with either congressional or executive branch personnel. As Richard Arnold, then chair of the Judicial Conference's Budget Committee, explained, "I was, in fact, appointed by the Chief Justice to this position precisely because I had been a legislative assistant to Senator Bumpers, who was then and still is a member of our Appropriations Subcommittee." Arnold, supra note 90, at 22; see also Thomas G. Walker \& Deborah J. Barrow, Funding the Federal Judiciary: The Congressional Connection, 69 JUDICATURE 43, 46-47 (1985) (discussing relationships between members of the Budget Committee and Congress).

106 While most of the federal judiciary's educational programs for judges are held under the auspices of the Federal Judicial Center, recent budget decentralization processes have given the AO a role in training judges to administer and disperse funds. See Conversation with AO staff (Sept. 23, 1998). According to Frank Gavin, Director of the Institute for Court Management at the National Center for State Courts, a parallel phenomenon is occurring in states; managerial training is now aimed at judges as well as at court staff. He estimated that judges constitute some 20 to $30 \%$ of attendees at sessions on court administration and that the percentage has increased in the last few years. See Frank Gavin, Remarks on the panel "The Education of a Judge" at the Annual Conference of the National Association of Women Judges (Oct. 10, 1998).

107 See supra notes $43-44$.

108 As the current Chief Justice explained. William H. Rehnquist, Chief Justice Recaps I995 in Year-End Report, THIRD BRANCH, Jan. I996 special issue, at I, I. Chief Justices have, of course, long given speeches in fora such as the ABA and the American Law Institute (ALI). The creation of an annual "state of the judiciary" speech was an innovation aimed at enhancing the judiciary's ability to make its point of view known to the public and Congress. The Chief Justice's annual speech is not, however, an official policy statement of the Judicial Conference. 
burdens) of proposed legislation affecting the federal courts. ${ }^{109}$ In addition, the AO tracks the number of new causes of action conferred by Congress on the judiciary. According to the AO count, 474 jurisdictional grants - "expanding the workload and jurisdiction of the federal courts" - were created between 1974 and I $998 .{ }^{110}$

In the I990s, "futures planning" matured. In 1995, the Judicial Conference adopted a Long Range Plan for the Federal Courts. ${ }^{111}$ This first-ever collective statement by the officialdom of the federal judiciary made ninety-three recommendations setting forth the judiciary's aspirations for the future of its criminal and civil docket, its trial and appellate courts, and its relationships to the state courts and Congress. ${ }^{112}$ Below I examine the interrelationships among some of the concerns that have occupied the federal judiciary during the twentieth

109 See CONFERENCE ON ASSESSING THE EFFECTS OF LEgISLATION ON THE WORKLOAD OF THE COURTS: PAPERS AND PROCEedINGS (A. Fletcher Mangum ed., I995) [hereinafter FJC LEGISLATIVE EFFECTS ON WORKLOAD CONFERENCE]. The quality of such predictions is the subject of debate. Given the many variables that affect a decision to file suit, social scientists are skeptical of the ability to determine the filing rates for new (as compared with extant) causes of action. See Frank Arnett \& A. Fletcher Mangum, Preliminary Findings: A Retrospective Analysis of the Effect of Legislation on the Workload of the U.S. Courts, in FJC LEGISLATIVE EFFECTS ON WORKLOAD CONFERENCE, supra, at 135-49; William Jenkins, Jr., Observations on Impact Models for the Federal Courts, in FJC LEGISLATIVE EFFECTS ON WORKLOAD CONFERENCE, supra, at $117-34$.

110 Administrative Office of the U.S. Courts, Revision of List of Statutes Enlarging Federal Court Workload (Sept. 18, 1998) (memorandum) (on file with the Harvard Law School Library) [hereinafter $A O{ }_{1098}$ Statute List] (noting that the tracking of such statutes began in 1974 and has since been periodically updated).

111 Judicial CONFERENCE of THE UNITEd STATES, LONG RANGE PLAN FOR THE FEderal COURTS (Dec. I995), reprinted in I66 F.R.D. 49 (1995) [hereinafter LONG RANGE PLAN]. The Judicial Conference formally approved the 93 recommendations and the 76 "implementation strategies." All "other text in the Plan, including commentary on the approved items, serves to explain the drafters' reasoning and provide background information but does not necessarily reflect the views of the Judicial Conference." Letter from L. Ralph Mecham, Secretary to the Judicial Conference, to all interested parties (Dec. 15, 1995), reprinted in I66 F.R.D. 5 I (1995) [hereinafter Mecham Letter] (introducing the Plan).

A few years earlier, a congressionally created commission, the Federal Courts Study Committee, had written a report also containing many recommendations, including recommendations for long range planning itself. See FEDERAL COURTS STUDY COMMITTEE, REPORT OF THE FEDERAL COURTS STUDY COMMITTEE I 5 I (I990) [hereinafter FCSC REPORT]. Congress created this committee in the Judicial Improvements and Access to Justice Act, Title I. Federal Courts Study Act, $\$ \S 101-109$, Pub. L. No. 100-702, \$§ I0I-109, Ior Stat. 4644 (1988) (codified temporarily as 28 U.S.C. $\$ 331$ "note").

Court-based "futures" planning began in the ro7os. In Hawaii, for example, such questions were included in a government-wide initiative called Hawaii 2000 . See JAMES A. DATOR \& SHARON J. RODGERS, ALTERNATIVE FUTURES FOR THE STATE COURTS OF 2020, at 67-78 (1991) (discussing the experiences of Hawaii, Virginia, and Arizona).

112 The LONG RANGE PLAN is addressed to "all interested parties." Mecham Letter, supra note I I I. The Plan's express purpose is to provide the judiciary with a comprehensive approach about its future. See LONG RANGE PLAN, supra note II , at I-3. Some of the recommendations are directed at Congress. See id. at 83 ("Congress should be encouraged to conserve the federal courts as a distinctive judicial forum of limited jurisdiction .... . 
century: its civil caseload, the number of judges within its ranks, the role of non-Article III judges, the delineation of judicial roles as adjudicators and administrators, and the development of an identity through a specific kind of caseload to distinguish federal from state courts.

\section{B. Collective Concerns}

As the 1995 Long Range Plan exemplifies, the infrastructure and policymaking processes of the judiciary have become the means of considering a broad spectrum of questions. An array of issues - from court reporters to counsel for indigent criminal defendants, from jury venire to probation - is similarly evident in the committee reports, transcripts, and correspondence that constitute the Conference's records during the past eighty years. ${ }^{113} \mathrm{My}$ focus here is narrower, on the interrelated developments of concerns about the numbers and kinds of cases, on views that not all judges who staff the federal judiciary were required to have life-tenure, and on the ways in which allocation of cases among differing categories of federal judges and between state and federal courts affected and reflected concepts of the federal courts as a distinctive and bounded venue.

While caseload complaints seem to have been ever-present, it is worth recalling that once the worry was having too few cases. The federal district court in Kentucky looked for business in the early I800s, ${ }^{114}$ and in the 1825 term, the Supreme Court decided 26 cases. ${ }^{115}$ The Civil War marked the beginning of the change. In the r86os and r87os, Congress deployed the federal courts as an instrument of control by authorizing the federal judiciary to hear cases including civil

113 See FISH, supra note 20 , at 269-300 (discussing the committee structure and some of the many issues atdressed).

114 See Mary K. Bonsteel Tachau, Federal Courts in The EARLY Republic: KenTUCKY $1789-1816$, at $28(1978)$. Fish describes district judges of the eighteenth and nineteenth centuries as "[i]solated and sometimes underworked." FISH, supra note 20 , at 13.

115 See FRANKFURTER \& LANDIS, supra note 38, at 302 tbl.I (Comparative Analysis of Supreme Court Business). Central questions that the Supreme Court faced in its first decades stemmed from its diversity jurisdiction; figuring out who owned what land was a formative "national" issue that preoccupied the Court. Included under "contracts related to land" were cases such as Fairfax's Devisee v. Hunter's Lessee, II U.S. (7 Cranch) 603 (1812); Martin v. Hunter's Lessee, I4 U.S. (I Wheat) 304 (1816); and Fletcher v. Peck, 10 U.S. (6 Cranch) 87 (1810). From 1790 to 1815 , diversity cases dominated the Court's docket, with a total of I35, followed by 84 admiralty cases. See John P. Frank, Historical Bases of the Federal Judicial System, I3 LAW \& CONTEMP. Probs. 3, I6 tbl. I (1948). Between 1815 and 1835 , the Supreme Court decided with full opinions 791 non-constitutional cases and 66 constitutional cases; the non-constitutional cases indicated a "continuing preoccupation with real property cases." G. EDWARD WHITE, THE MARSHALl COURT AND CUlTuRal CHANGE, I815-35, at 747 (1988). By White's count, the Court decided I72 such cases, as well as 24 international law cases, some of which involved aliens' claims to land. See id. 
rights, ${ }^{116}$ habeas corpus, ${ }^{117}$ and other claims arising under general "federal question" jurisdiction. ${ }^{118}$ The docket of the federal judiciary expanded through the end of the nineteenth century and on through the New Deal, as Congress continued using the federal courts to craft and to implement national agendas.

Thereafter, a series of legislative enactments about consumer, environmental, and worker protection, coupled with statutes focused on civil rights, created conditions for more filings. Between the I 960 s and I 990 , both the number of judgeships and the number of cases filed tripled. ${ }^{119}$ The growth in both the quantity and kinds of cases prompted complaints about workload.120 In fact, the need to have a means by which to complain in the nineteenth century (particularly about the docket of the Supreme Court) was one reason for the creation of an administrative apparatus in the twentieth century. ${ }^{121}$ The issue explored below is what charter such an institution, located within the Third Branch, has and should adopt.

I. Changing Attitudes About Authority. - The question of which persons or organizations should register complaints about judicial resources has been answered differently over time. Lawyers did much of the petitioning and lobbying during the nineteenth century; ${ }^{122}$ the Department of Justice served until 1939 as the institutional voice for the federal judiciary. ${ }^{123}$ Individual Justices began going to Congress -

116 See The Civil Rights Acts of $187 \mathrm{I}$, Act of Feb. 23, 187I, ch. 49, 8 I3, 16 Stat. 433, 437; Act of Apr. 20, I871, ch. 22, \& I, I7 Stat. 13, 13.

117 See Act of Feb. 5, 1867, ch. 27, 14 Stat. 385 .

118 See Act of Mar. 3,1875 , ch. I37, § I, I8 Stat. 470, 474. See generally William M. Wiecek, Murdock v. Memphis: Section 25 of the 1789 Judiciary Act and Judicial Federalism, in ORIGINS OF THE FEDERAL JUDICIARY 223-47 (Maeva Marcus ed., I992).

119 See 1998 AO Judgeships/Filing Data, supra note I8 (during thirty-year intervals before the 1960s, the numbers of life-tenured judges and of cases doubled). Note that numbers alone are an inadequate measure; "weighted" case filings attempt to capture the amount of judicial time different kinds of cases are expected to take. One analysis concluded that the workload of district judges "doubled between 1962 and I988." Larry Kramer, "The One-Eyed Are Kings": Improving Congress's Ability to Regulate the Use of Judicial Resources, 54 LAW \& CONTEMP. PROBS. 73, 74 (I99I).

120 In the words of Felix Frankfurter and James Landis, the number of filings in the Supreme Court in 1890 reached "the absurd total of 1800 . The lower courts showed the same break-down of judicial organization." FRANKFURTER \& LANDIS, supra note 38, at 86.

121 See generally FisH, supra note 18 ; supra notes $36-38$.

122 According to the account by Frankfurter and Landis of activities during most of the nineteenth century, "[e]ven the members of the Supreme Court felt impelled to speak" in 1887 to the question of the Supreme Court docket. FRANKFURTER \& LANDIS, supra note 38, at 96-97.

${ }^{123}$ See supra note 20; supra p. 950. 
mostly to discuss budgets - with some regularity in the $1920,^{124}$ and individual judges lobbied members of Congress as well. ${ }^{125}$

Such contact is, for me, not problematic. As products of the political process ${ }^{126}$ and either as citizens or as specially situated experts, judges have communicated and should provide their views to elected representatives. ${ }^{127}$ (A different issue is whether such efforts should be undertaken openly; the answer resides in conceptions of judicial neutrality and whether "extra-judicial" expressions of views by judges should be made known to litigants.)

My interest is the claim that "the federal judiciary" has an opinion, and specifically one about which cases Congress should assign to it. With the creation of the Conference of Senior Appellate Judges in I 922 , the potential for the judiciary to speak as an institution emerged. After the Administrative Office was formed in I939, the discussion between the judiciary and Congress was no longer filtered through the Attorney General. Because the Conference's charter was to assess the state of the "business in the courts,"128 the issue was not whether the Conference would provide information to Congress but on which topics to take a position, qua judiciary. One answer that came easily was that the judiciary should inform Congress about the need for more

124 See Rishikof \& Perry, supra note 90, at 673-75 (describing appearances by Justices most frequently before congressional committees to discuss budgets).

125 See, e.g., Minutes of 1922 meeting ro- I, in Judicial Conference Meetings Records, supra note 50, at Box I (Dec. I922-Sept. 1923) (indicating that Chief Justice Taft, concerned about the need to reform Supreme Court jurisdiction, urged that each judge be given a copy of then pending legislation so as to "write personal letters advocating ... passage to members of the House and Senate, observing that if the Judges could speak of their own personal knowledge of the bills it would have much greater effect"). According to the official report of the proceedings, "[w]hile no formal action was taken by the conference with regard to these bills, the consensus of opinion was that the changes ... were advisable and should be put into effect." The Federal Judicial Council, 2 TEX. L. REV. 458, 459 (1924) (reprinting in full the I 922 JUDICIAL CONFERENCE REPORT).

126 William Howard Taft, who had served as President of the United States, is an example; as Chief Justice, he was actively involved in many campaigns for legislation. See, e.g., FISH, supra note 20 , at 85 (describing Taft's campaign against restrictions on diversity jurisdiction); supra note 125.

127 For discussion of ethical and statutory constraints on judicial involvement in the legislative process, see Charles Gardner Geyh, Paradise Lost, Paradigm Found: Redefining the Judiciary's Imperiled Role in Congress, 7 I N.Y.U. L. REV. II65, I192-1204 (I996) [hereinafter Geyh, Paradigm Found].

128 Act of Sept. 14, 1922, ch. 306, \& 2, 42 Stat. 838 (1922) (providing that "[s]aid conference shall make a comprehensive survey of the condition of business in the courts of the United States and prepare plans for assignment and transfer of judges ..., and shall submit such suggestions to the various courts as may seem in the interest of uniformity and expedition of business"). The current formulation, 28 U.S.C. $\$ 33$ I (1994), provides that the Conference should survey the "condition of business in the courts of the United States" and requires the Chief Justice to "submit to Congress an annual report of the proceedings of the Judicial Conference and its recommendations for legislation." 28 U.S.C. 833 I (1994). 
judgeships; such requests have been made repeatedly throughout the twentieth century. 129

The conversation about judgeships that ensued with Congress prompted a dialogue about the efficacy of judicial practices and plainly affected some of the judiciary's agendas. In the judiciary's records are comments about what judges thought Congress was interested in (for example, pre-trial processes) and how the judiciary might enhance its ability to demonstrate need to Congress (for example, by improving data collection about pending cases). Seeking funding for additional judgeships, law clerks, and better libraries, the judiciary found itself obliged to justify some of its customs. The Judicial Conference's special Committee on Air-Conditioning ${ }^{130}$ (formed in the r 950 ) and a survey of judges about their vacation practices, ${ }^{131}$ for example, came in response to newspaper accounts of closed courts during summer months. ${ }^{132}$

129 Beginning with the first meeting of the Conference of Senior Circuit Judges in 1922 , the judiciary discussed staffing needs and whether to request additional judgeships. Transcripts of the early meetings can be found at the National Archives; those meetings included reports from each senior circuit judge about the ability of each judge sitting within that circuit to keep dockets current. See Judicial Conference Meetings Records, supra note 50, at Boxes 2 (Sept. 1923-June 1925) to 2 I (Sept. I94I-Sept. I94I); see also FISH, supra note 18, at 56-57 (describing such exchanges). As Fish explains, requests for additional judgeships and reconfiguration of judicial boundaries were sometimes also prompted by interest in altering the composition of a particular court's bench. See id. at 66-67 (describing an example of "special conditions," to wit, a disliked sitting judge, and the request for an additional judgeship in Kansas).

An example of a request for additional judgeships at the other end of the twentieth century is the Federal Judgeship Act of 1999, S. 1145 , I O6th Cong., Ist Sess. (May 27, 1999), which reflects the Judicial Conference's proposal for 69 additional judgeships, II of which are for the appellate courts. Despite efforts by the judiciary, as of October 1999 the bill had not been considered by the Senate Judiciary Committee. See Legislation Moves Slowly as End of Session Nears, THIRD BRANCH, Oct. I999, at 8.

130 Letter from R.O. Jennings, the Acting Commissioner of Public Buildings, to AO Director Chandler (Sept. 12, 1952), in Judicial Conference Meetings Records, supra note 50, at Box 58 (Mar. 1952-Sept. 1952) (declining to fund the request for air-conditioning given fiscal constraints); Item 30 (1954), in Judicial Conference Meetings Records, supra note 50, at Box 67 (Apr. 1954 Apr. 1954) (noting the urgency of the problem and providing a list of requests of buildings to be air conditioned and the names of senators and representatives from those areas); Report, in Judicial Conference Meetings Records, supra note 50, at Box 75 (Mar. 1955-Sept. 1955) (reporting some progress, as of June I6, I955, from the Air Conditioning Committee, chaired by John Parker).

131 See Joint Report of Committees on Court Administration and on Supporting Personnel, in Judicial Conference Meetings Records, supra note 50, at Box 76 (Sept. 1955-Sept. 1955), Folders 5, 6 (seeking information on vacations taken); Report of the Judicial Conference Committee on Court Administration, re: Judicial Vacations, in Judicial Conference Committee Records, supra note 50, at Box 7 ; see also 1956 JUDICIAL CONFERENCE REPORT I I-I 2.

132 Letter from Bolitha Law (Sept. 10, 1956), in Judicial Conference Committee Records, supra note 50, at Box 7, Folder 16 (discussing vacation policy). The archive also included clippings of stories from Washington newspapers reporting on controversy over vacations taken by judges. The I955 JUDICIAL CONFERENCE REPORT concluded that air conditioning was necessary in the "interest of efficiency" because of the "practical impossibility of holding court during summer 
In the initial years of self-governance, the judiciary's leadership worried about its side of the conversation and, specifically, about the idea of the Article III judiciary opining. In the early 1920s, the Conference of Senior Circuit Judges described itself as serving to make "the organization of the Federal force of judges into a more effective means of doing the work assigned by the law to the judiciary of the National Government."133 Whether to do more was unclear. In the stenographically transcribed proceedings of its first decades, ${ }^{134}$ judges periodically mentioned the limits of their authority and questioned whether taking positions on certain issues was appropriate.

Yet during the first decade of the Conference's existence, judges within the Conference thought about expanding its charter. In the early 19305, under the leadership of Chief Justice Charles Evans Hughes, whether to seek legislation to broaden the Conference's mandate beyond commentary on "congestion of the courts and the remedies for it"135 came into question. The Chief Justice suggested ob-

months in many areas," and that the absence of air conditioning "has led sometimes to long vacations and unnecessary delay in disposing of judicial business." I955 JUDICIAL CONFERENCE REPORT 20.

A 1957 committee report also noted the difficulty in seeking judgeships while having to explain to Congress "the failure" to hold "more sessions during the summer months in view of the pressure of business." See Joint Report of Committees on Supporting Personnel and Court Administration 13 (Aug. 29, I957), in JUDICIAL CONFERENCE RECORDS/AO Collection, supra note 50 , at Binder Sept. I957, item 5.

The Executive has also played a role in shaping the judiciary's sense of itself. In 1937, for example, the Conference of Senior Judges debated whether it should take a stance different from that of the Attorney General. Chief Justice Hughes stated that "as a judicial conference organized under the statute we should express our own views, and of course if [the Attorney General] agreed with them, that would be very agreeable to us ...." Transcript 147-51, in Judicial Conference Meetings Records, supra note 50, at Box 13 (I937).

133 Handwritten notes in a report, in Judicial Conference Meetings Records, supra note 50, at Box I (Dec.1922-Sept., 1923).

134 The first full transcript I have located comes from 1925. See Transcript of June 9, 1925 meeting, in Judicial Conference Meetings Records, supra note 50, at Box 2 (Sept. 1923-June 1925). The last in the archives is from 1941. See Transcript, in Judicial Conference Meetings Records, supra note 50, at Box 2 I (Sept. 194 I-Sept. I94I). On the August 25, 1942, agenda, a tabbed item indicated that stenographic transcription was a topic to be discussed. See Agenda, in Judicial Conference Meetings Records, supra note 50, at Box 25 (Sept. I942-Sept. I942), Item No. 4. No material from that discussion was included, but transcripts are not part of the post-194I records stored at the National Archives, nor part of the notebooks, from 1995 to the present, stored in the General Counsel's Conference Room at the Thurgood Marshall Building.

135 See Transcript 304, in Judicial Conference Meetings Records, supra note 50, at Box 6 (October 1929-October 1930), Folder 1930 Minutes and Transcript with index (hereinafter 1930 Transcript]; see also 1930 REPORT OF THE JUDICIAL CONFERENCE 6 (noting that "[t]he Conference also took into consideration the appropriate development of its own work as an effective agency for the improvement in the administration of justice in the federal courts" and sought from Congress legislative amendment of its charter "to make clear its authority"). The Chief Justice subsequently noted that the statute could be liberally interpreted but that the Conference could be a "considerable force in the field of legislation" but had to "keep clear of any questions of policy." 
taining congressional authorization to comment on "laws affecting jurisdiction, evidence, and procedure in the Federal Courts,"136 and the Conference concurred. ${ }^{137}$ The amendment proposed by the Conference was never enacted. By I934, the Chief Justice suggested that the Conference "say nothing more about it."138 Over the decades, however, the Conference gave itself the permission it thought it had needed from Congress.

Discussion specifically about jurisdiction, however, did not come readily. For example, in $\mathrm{I}_{932}$, in the context of a bill proposing to abolish federal diversity jurisdiction, ${ }^{139}$ members of the Conference worried about whether to express an opinion (in that era in favor of retaining jurisdiction). ${ }^{140}$ As one judge argued:

See Transcript 252-53 (1931), in Judicial Conference Meetings Records, supra note 50, at Box 6 (October 1929-October 1930), Folder 1930 Minutes and Transcript with index.

In contrast, from early on, the judiciary's policymaking body appeared willing to make suggestions about sentencing and did not discuss that arena as outside its bailiwick. See 1929 REPORT OF THE JUDICIAL CONFERENCE 6 ("The federal system for the punishment of violations of the Federal criminal statutes offers an opportunity to the Federal courts to lead in the matter of this reform.").

136 See Transcript 322 (Oct. 3, I930), in Judicial Conference Meetings Records, supra note 50, at Box 6 (October I929-October 1930), Folder I930 Minutes and Transcript with index.

137 See id. at 335 (resolving to ask the Attorney General to introduce such legislation to permit commentary on the jurisdiction of the lower federal courts); see also I930 JUDICIAL CONFERENCE REPORT, reprinted in ANNUAL REPORT OF THE ATTORNEY GENERAL OF THE UNITED STATES FOR THE FISCAL YEAR I930, at 6 (reporting that "[i]n order to avoid any question as to the scope of authority which Congress intended to confer upon the Conference," the Conference urged a legislative change to authorize that it make recommendations for "such changes in statutory law affecting the jurisdiction, practice, evidence and procedure" as it thought appropriate); 193 I JUDICIAL CONFERENCE REPORT, reprinted in ANNUAL REPORT OF THE ATTORNEY GENERAL OF THE UNITED STATES FOR THE FISCAL YEAR 1931, at 4, I2 (including the same request, to avoid "any question as to the scope of the authority which the Congress intended to confer upon the Conference"); 1932 JUDICIAL CONFERENCE REPORT, reprinted in ANNUAL REPORT OF THE ATTORNEY GENERAL OF THE UNITED STATES FOR THE FISCAL YEAR 1932 at 6, 12 (I932) (reporting that the Attorney General had informed the Conference that such legislation was pending and that the Conference had "renew[ed] its recommendation as to the advisability of this legislation").

138 See Transcript 134 (1934), in Judicial Conference Meetings Records, supra note 50, at Box I0.

139 See Hearings on S. 937, S. 939, and S. 3243 Before Subcomm. of the Senate Comm. on the Judiciary, 72nd Cong., Ist Sess. (1932) [hereinafter 1932 Hearings]. Attorney General William Mitchell discussed the bills with the Conference and argued that, given local prejudices, maintaining diversity jurisdiction was essential. See 1932 Transcript 31-33, in Judicial Conference Meetings Records, supra note 50, at Box 8 (statement of Attorney General Mitchell); see also Letter from William Mitchell, Attorney General, to Senator George W. Norris (May 26, I930), in I932 Hearings, supra, at 5. By the late 1970s, the Conference had changed its position and approved of a bill that would abolish most diversity jurisdiction, and reiterated that if such legislation were not enacted, it would continue to support limitations on filings by in-state plaintiffs and increases in the jurisdictional amount. See 1977 JUDICIAL CONFERENCE REPORT 8-9, 52.

140 See 1932 Transcript 234-35, in Judicial Conference Meetings Records, supra note 50, at Box 8 (exchanges between Judges Wilber and Alschuler). While the Judicial Conference continued to be supportive of diversity jurisdiction through the 1950s, the Supreme Court's 1938 decision in 
But for us, as a Conference, created by law, of Federal Judges, representing the sense of Federal Judges, to express ourselves on contemplated legislation to grant or to withdraw jurisdiction from the Federal Courts - to give a jurisdiction which it lies within the power of Congress to grant or to withdraw - it seems to me to be rather presumptive on our part, if we undertake it officially. ${ }^{141}$

Offering his personal views, Chief Justice Hughes concurred, commenting that it would be "inappropriate ... for the Conference to express its opinion;" he explained that the Conference would be placed in a "very vulnerable position if [the judges] undertake to defend their own jurisdiction" because it would "weaken their position, their prestige, and their independence, if they appeared to be campaigning in their own interests."142 He said:

Rather, the federal judiciary was to do its job as judges, in accordance with the legislation and the Constitution ... [and] if we do that job as wisely and as efficiently as we know how, we will do more to protect the Federal Judiciary than we can in any other way. ${ }^{143}$

In his view, judges could undertake individual efforts and enlist assistance (as in the past) from bar associations, but no official position on behalf of the Third Branch should be advanced in Congress (here again in support of retaining jurisdiction). ${ }^{144}$

The sense that a co-mingling of functions posed risks for the judiciary was reflected in the later I930s as well, as the Conference worked on proposals for what became the Administrative Office of the Courts. The Chief Justice reported concerns from other members of his Court that an administrative apparatus within the courts not become so closely identified with the Supreme Court that the Chief Justice or the Court be seen as responsible for administrative decisions. ${ }^{145}$

The shift in the Conference's posture began around the time of the creation of the Administrative Office, after which the Conference's ex-

Erie Railroad Co. v. Tompkins, 304 U.S. 64 (1938), curtailed the federal judiciary's role in those cases and altered the incentives for filing them. Court rulings affecting diversity before Erie are detailed in PURCELL, BRANDEIS AND THE PROGRessive CONSTITUTION, cited above in note 19.

141 See 1932 Transcript 237A, in Judicial Conference Meetings Records, supra note 50, at Box 8 (Judge Alschuler).

142 Id. at $241-42$.

143 Id. at 243. Purcell examines how, through adjudication, the court adjusted the boundaries of federal judicial authority. See PURCELl, BRANDEIS AND THE PROgRessive CoNSTITUTION, supra note I9. Further, that the Conference in the I930s took no position is not to say that individual judges did not attempt to influence congressional policy - both through adjudication and through personal appeals. See $i d$. at 77-85.

144 I932 Transcript 237A, in Judicial Conference Meetings Records, supra note 50, at Box 8.

145 See Transcript, Vol. II, at 180-86 (Sept. 30, 1938), in Judicial Conference Meetings Records, supra note 50, at Box 14 (September I937-September 1938); see also FISH, supra note 20, at 137 
changes with Congress became more direct. ${ }^{146}$ In the Conference's 194I meeting, members welcomed the chairs of the relevant congressional committees to enable "interchange of views by representatives of the judicial and legislative branches of government on pending or prospective legislation affecting the work of the courts."147 During the I 940 , the Conference began to consider suggestions about habeas corpus jurisdiction, ${ }^{148}$ as well as a proposed bill limiting federal Fair Labor Standards Act jurisdiction. ${ }^{149}$

As the Conference's interests and concerns broadened, another question emerged - about the Conference's authority to speak to and for judges within the Third Branch. District judges began to complain that although the Conference was working on matters related to the trial courts (such as promoting pre-trial procedures through surveys and committees), it did not include district judges as members. ${ }^{150}$

146 This essay is not the place to recount all of the evolution. Peter Fish argues that the recommendation in 1937 by the Conference of a public defender system foreshadowed a shift from a constrained view of the Conference's mandate and that the establishment of the AO in I939 expanded the judiciary's policy-advising role. See FISH, supra note 20, at 68-69. More recently, Charles Geyh has described what he terms as three stages of judicial-congressional interaction, the first (I789-I922) "unstructured," the second (I922-66) "formalized," and the third (I967present) "expanded." See Geyh, Paradigm Found, supra note 127 , at $1171-83$.

Many factors contribute to increased efforts by the judiciary to affect a wider range of legislative actions. As different Chief Justices have chaired the Conference, their own attitudes toward the role appropriate for the Third Branch have been influential. In addition, the courtpacking plan, the rise of a national bar with hierarchical aspirations of its own, congressional hearings on the judiciary, and political debates over specific aspects of the federal judicial docket affected the federal judiciary's understanding of the role it would and should take in developing programmatic agendas.

The reach of the Conference's authority within the judiciary - and when it trenched on adjudicatory prerogatives - has also been a subject of debate. See, e.g., FiSH, supra note 20, at 73-74, 87-90 (discussing the Conference's issuance of rules, such as when bail would be available, that might otherwise have been decided through adjudication and observing that, because of an understanding of district judges as "autonomous," such directives were not always followed); see also infra note 150; infra Part VI.A.

147 See Handmarked copy of the Judicial Conference Report I (Sept. 194I), in Judicial Conference Meetings Records, supra note 50, at Box 16 . The official version of this document is printed in 194 I JUDICIAL CONFERENCE REPORT, in ANNUAL REPORT OF THE ATTORNEY GENERAL OF THE UNITED STATES FOR THE FISCAL YEAR I941, at 28.

148 See Item 18, in Judicial Conference Meetings Records, supra note 50, at Box 26 (Sept. 1942Sept. I942); Document summarizing comments, in Judicial Conference Meetings Records, supra note 50, at Box 29 (Sept. 1943-Sept. 1943), Folder Sept. 1942 (summarizing comments on the habeas proposal including those of Judge Alfred Murrah, opposing legislation whose purpose he saw to be a "contraction of jurisdiction" to enforce rights secured by the Constitution).

149 See Letter from Henry Chandler, Director of the AO (Mar. 15, 1943), in Judicial Conference Meetings Records, supra note 50, at Box 28 (Sept. 1942-Sept. 1943) (seeking the Conference's views on the bill).

150 See Agenda of Aug. 14, 1944 meeting 5-6, in Judicial Conference Meetings Records, supra note 50, at Box 32 (Apr. I944-Sept. 1944) (including discussion of the committee on representation of district judges and its report on the limits of the Conference's powers). The compromise was called the "Phillips plan" after the chair, Orie Phillips, of the committee delegated to study the issue. District judges became members in 1957. See Act of Aug. 28, 1957, Pub. L. No. 85-202, 
Some Conference members did not want to enlarge their ranks beyond appellate judges; after surveying district judges, ${ }^{15.1}$ the Conference agreed that when possible, if considering matters relevant to district judges, it would obtain input from district judges through questionnaires, which would be summarized and abstracted by AO staff and provided to Conference members in advance of its taking a public position. ${ }^{152}$ The Conference also regularly sought information from the circuits; on occasion, when circuits (by means of resolutions) objected to a proposed position, the Conference retreated. ${ }^{153}$

Given the absence of archived stenographic records after the early 1940s, I cannot report what discussions ensued that resulted in the decline of judicial polling and the end of self-restraint about commentary on the scope of federal court jurisdiction. What I can report is that (a) the sense of what a judicial body ought to say changed during the second half of the century; (b) what posture to take was contested; and (c) frustration with the Congress and Executive was identified by judges as a source of why they had to become more active in controlling their dockets through case load management, jurisdictional commentary, and consideration of alternative decisionmakers. ${ }^{154}$

During the 1950s, the Conference began to consider which aspects of jurisdiction could be cut back and which could be shifted to alternative venues. This was the decade in which the entity of the judiciary began to be heard suggesting that Congress refrain from creating certain new federal causes of action and delegate non-life-tenured judges to undertake more of the tasks associated with judging. Limitations on habeas corpus, alterations in diversity jurisdiction, arbitration for car accidents, creation of administrative courts, means for review of Veteran Bureau decisions, and reassignment of decisions on

7 I Stat. 476; see also FISH, supra note 20, at 248-54 (describing the debates about inclusion of district judges); infra note 375 (discussing questions of representation of magistrate and bankruptcy judgesi).

151 See 1945 REPORT OF THE JUDICIAL CONFERENCE 8-9.

152 See, e.g., Item 6, in Judicial Conference Meetings Records, supra note 50, at Box 62 (Mar. I953-Mar. I(953) (providing an abstract of comments of judges on the controversy surrounding whether to propose interlocutory appellate jurisdiction); see also FISH, supra note 20, at $25 \mathrm{I}$.

153 See Memorandum of Sept. 4, I94I, in Judicial Conference Committee Records, supra note 50 , at Box I r, Folder Sept. 1942 (including discussion of circuit resolutions disapproving of an indeterminate-sentence act that the Judicial Conference had initially approved).

154 As Charles Clark put it in his 1955 committee report to the Conference, the backlog stemmed from the "failure of Congress and the Executive Branch of government to act promptly on the recommendations of the Judicial Conference and to fill new positions and vacancies with expedition." Committee report (1955), in JUDICIAL CONFERENCE RECORDS/AO COLLECTION, supra note 50, at Binder 1956 Reports, Item I Reports to the Judicial Conference. The judiciary was affirmed in its views by the Executive; the Attorney General warned of docket congestion. See also 1956 JUDICIAL CONFERENCE REPORT app. at 5 I (Report of Attorney General Herbert Brownell, Jr., to the Judicial Conference) ("Delay in litigation continues to be the primary problem in the administration of justice in most of our federal and state courts."). 
seamen's wages to hearing officers all came before the Conference. ${ }^{155}$ That debate ensued on what positions to take can be surmised from differences between committee reports (which sometimes urged the Conference either to take no position because "broad questions of public policy" were raised ${ }^{156}$ or to approve specific provisions creating jurisdiction ${ }^{157}$ ) and Conference action, sometimes rejecting such advice.

During the following forty years of discussions with Congress, the federal judiciary came to see itself as specially situated to comment on proposed provisions creating new causes of action. Moreover, in the course of advising Congress about what kind of cases should be sent to federal courts and which sent away, the judiciary developed a discourse about its distinctive work and mandate. By the I9gos, the Judicial Conference argued against assignment to the federal courts of particular kinds of cases, such as claims arising under the Social Security Act $^{158}$ and the Federal Employer Liability Act, ${ }^{159}$ and a wide vari-

155 See, e.g., Report of the Committee on Supporting Personnel \& the Committee on Court Administration I6 (Aug. 16, I956), in Judicial Conference Committee Records, supra note 50, at Box 4, Agenda Item 5 and 6 (describing support for a proposal that "civil actions filed in the district courts under the diversity jurisdiction arising out of motor vehicle accidents be referred to compulsory arbitration"); see Transcripts of Congressional Hearings, in JUDICIAL CONFERENCE RECORDS/AO COLLECTION, supra note 50, at Binder March 1956. The proposed habeas legislation is also described in A Bill to Amend \$ 2254: Hearings on H.R. 5649 Before Subcomm. No. 3 of the House Comm. on the Judiciary, 84th Cong., Ist Sess. (1955); according to those hearings, in 1955, a committee of the Conference, "in collaboration with the representatives of the State chief justices and the State attorneys general, prepared" a statute to limit prisoners' habeas corpus filings. Id. at 7 (statement of John Parker, chair of the Judicial Conference committee on habeas issues).

156 Joint Report of the Committee on Court Administration \& Revision of the Laws 2 (Sept. 3, I958), Binder Mar. I958, in JUDICIAL CONFERENCE RECORDS/AO COLLECTION, supra note 50 (discussing proposals to create administrative courts for the National Labor Relations Board and the Federal Trade Commission); see also Committee on Revision of the Laws, Aug. 15, I958 by its chair, Albert Maris, at 3. The Committee on Revision of the Law advised consideration of:

[t]he question of extending the jurisdiction of the district courts to decide questions of law arising in maritime arbitrations as involving a question of public policy for Congress to decide, the federal courts being, of course, willing to access and discharge to the best of their ability any such additional jurisdiction as Congress may see fit to confer upon them. We cannot ignore in this connection, however, the fact that if a substantial amount of judicial business is given to the presently congested district courts in the metropolitan port centers additional judicial manpower will have to be provided if further congestion and delay is not to result.

Id. Handmarked in red next to this entry is "postponed indefinitely." Id.

157 Not all members of the Conference agreed. For example, the Committee on Revision of the Laws proposed support of an amendment (H.R. 272) providing for judicial review of decisions made in the Bureau of Veterans' Affairs. See Report of the Committee on Revision of the Laws 4 (Aug. 28, 1957), in JUdiCIAL CONFERENCE RECORDS/AO COLlECtION, supra note 50, at Binder Sept. I957, Item 16. The Conference, in its report, took no position. See I957 JudiCial CoNFERENCE REPORT 36.

158 See LONG RANGe PLAN, supra note III, at 33 (Recommendations 9a and gb); see also FCSC REPORT, supra note III, 55-60 (including different proposals about structure, one from the majority and one from dissenters).

159 See LONG RANGe PLAN, supra note III, at 35 (Recommendations 12, 12a, and 12b); see also HENRY J. FRIENDLY, FEDERAL JURISDICTION: A GENERAL VIEW I97-99 (1973). 
ety of other federal statutory claims. In 1999, the Judicial Conference opposed "expanded jurisdiction in $\mathrm{Y}_{2} \mathrm{~K}$ legislation" as "inconsistent with the long-held principle that the federal courts should be preserved as tribunals of limited jurisdiction."160 Facets of that conversation the conceptions of the federal judiciary as specially important, distinctive, and at the top of a hierarchy of adjudicators - are explored below.

2. Redefining the Work Appropriate for Life-Tenured Judges. Distress about workload can prompt a range of reforms. One response, found repeatedly during the past 150 years, is to seek more federal judgeships and new courts to handle the work. In the nineteenth century, the increase in the Supreme Court's docket in the postCivil War era was a part of the impetus ${ }^{161}$ for creation of an intermediate appellate level, which would take cases from the Supreme Court and spread them across additional courts, staffed by life-tenured judges. ${ }^{162}$ The narrative of much of the twentieth century includes the same leitmotif: a federal judiciary, qua judiciary, frequently petitioning Congress to increase its numbers to match its workload. ${ }^{163}$

Such a posture - adding judges and concomitant resources might, if successful, suffice. The federal judiciary, posited as a "rational actor," might be assumed always to seek to maximize its own

160 Judicial Conference Opposes Expanded Jurisdiction in $\mathrm{Y}_{2} \mathrm{~K}$ Legislation, THIRD BRANCH, May I 999 , at 4-5.

161 The perceived need to increase supervision of trial judges was another reason to make appellate review more widely available. Because, under the circuit system, district judges could sit in review of their own decisions, critics argued that such appeals were "not from Philip drunk to Philip sober, but from Philip sober to Philip intoxicated with the vanity of a matured opinion and doubtless also a published decision." FRANKFURTER \& LANDIS, supra note 38 , at 87 (citation omitted).

162 The creation of the intermediate tier also altered the kind of work that appellate judges did. A parallel to the role transformation within the trial bench in the second half of the twentieth century, see supra pp. 929-45, can be found in the nineteenth century. Before the creation of a separately staffed intermediate appellate tier, Supreme Court Justices worked as appellate judges and occasionally sat, in their capacity as members of circuit courts, as judges of courts of first instance. In contrast, today neither federal appellate judges nor justices preside at trials except by special assignment.

Concurrent roles do continue for other judges. For example, district judges in the United States review the work of magistrate and bankruptcy judges. Further, judicial systems outside the United States provide for judges to work at both appellate and trial levels. For example, in Israel, the Supreme Court serves as an entry level court for certain kinds of disputes. See MARTIN EDELMAN, COURTS, POLITICS, AND CULTURE IN ISRAEL 32 (1994) (discussing that court's "equity jurisdiction ... as a court of first instance"

163 See, e.g., The Business of the Federal Courts in the Past Fiscal Year, as reviewed in the Annual Reports of the Administrative Office of the U.S. Courts 3 (draft of Sept. 25, 1947), in Judicial Conference Meetings Records, supra note 50, at Box 43 (Apr. 1947-Apr. 1947), Folder Sept. 1946, "[W]hen it is plain that a court has a greater burden than it can carry, and that condition appears to be permanent, the only solution is for the Congress to increase the number of resident judges $\ldots$, the rights of litigants suffer unless this is done." Id. 
authority through congressional conveyances of jurisdiction over an ever wider range of issues, so long as that jurisdiction was accompanied by increases in judicial person-power. Moreover, new judgeships would enable the federal judiciary to expand its geographical reach, thereby enhancing the "federal presence." 164 But the federal judiciary has developed a different sense of what kind of authority to seek and what maximizing means. Rather than always ask for more, the federal judiciary has come to ask - most vividly in the I990s - for less: fewer cases, different cases, fewer life-tenured judges, and more subsidiary, statutory judges.

The arguments for reduction of federal judicial business and of lifetenured personnel depend upon either (or both) of two views. One is that, as a matter of constitutional law, Congress is prohibited from authorizing the federal courts to decide certain kinds of cases. Over the twentieth century, and again vividly in the r9gos, federal judges have occasionally so held, finding specific grants of jurisdiction illegal. ${ }^{165}$ The other position is that, as a matter of policy, Congress should not give certain jurisdictional grants to federal judges. Over the century, the federal judiciary has come to adopt this view as well, in part by constructing an identity of being not only too busy but also too "important" for certain kinds of matters, appropriately relegated to other judges.

(a) "Important" Cases. - This idea of importance and its relationship to particular cases on a docket require explication. The federal courts might have been seen as important in the sense that under the United States Constitution, federal law is supreme and hence can be imposed - even over protest ${ }^{166}$ - on state courts. During the nineteenth and twentieth centuries, federal judges developed asymmetrical doctrines that limited the power of state courts to issue orders to federal officials ${ }^{167}$ but authorized federal courts to impose certain obligations on state officials. ${ }^{168}$ The federal judiciary's importance could

164 See, e.g., FISH, supra note 20, at 51 (recounting how Chief Justice Taft endorsed a new judgeship for the Southern District of Florida after a member of Congress informed him of the distances between cities in Florida).

165 See Alden v. Maine, I 9 S. Ct. 2240, 2246 (1999); College Sav. Bank v. Florida Prepaid Postsecondary Educ. Expense Bd., II S. Ct. 22 19, 2233 (I999); Florida Prepaid Postsecondary Educ. Expense Bd. v. College Sav. Bank, 1 I9 S. Ct. 2 I99, 2202 (1999); Seminole Tribe v. Florida, 5 I 7 U.S. 44, 47 (1996); United States v. Lopez, 5 I 4 U.S. 549, 55 I (I995).

166 See, e.g., Cooper v. Aaron, 358 U.S. I (I958); Martin v. Hunter's Lessee, I4 U.S. (I Wheat.) 304 (1816) (both arising from challenges by state officials to the supremacy of federal law as interpreted by the Supreme Court).

167 See Tarble's Case, 80 U.S. (13 Wall.) 397, 4 I0 (1872). See generally 28 U.S.C. $\$ 1442$ (I994 \& Supp. III 1997) (providing for federal jurisdiction by removal over claims against federal officials).

168 This power is currently contested in the evolving Eleventh Amendment jurisprudence. During the past few years, the Court (in 5-4 decisions) has relied on a reading of the Eleventh 
thus rest on its adjudicatory muscle, unequaled by either state or tribal court systems within the country.

But a second and different kind of hierarchical claim is also made - about superiority not in the constitutional sense of the Supremacy Clause but in the cultural sense of the meaning and import of the work. Federal judges describe their courts as the venue for "important" matters, as contrasted (implicitly and sometimes explicitly) with "ordinary," "routine," "run of the mill," "run of the mine," "garden variety" (pick your metaphor) litigation.

The turn to such contrasts between the ordinary and the important is not intrinsic in role differentiation. Difference does not necessarily entail superiority. ${ }^{169}$ One might have a political theory of multiple spheres of governance that relies on distinctive mandates to create and preserve specific identities. ${ }^{170}$ But the construction of federal judicial distinctiveness has not rested only on "neutral" differences (you do torts, we'll take contracts; you do fraud, we'll do bank robbery). Superiority is claimed. ${ }^{171}$

Another wrinkle: "More important" could (simply) be equated with whatever is "federal." If Congress assigns a particular kind of case to the federal courts ("makes a federal case out of it"), then that case could be deemed more important than if sent to state courts. Federal judges might thus see their docket as a perfect fit, matching their own conceptions of import. But federal judges seek not only to receive federal cases, but also to define the meaning of "the federal" - to have only the "right" federal cases sent their way. To that end, in both their adjudicatory and administrative capacities, federal judges worked during the later part of the twentieth century to circumscribe what should be federal.

Amendment and its role in the Constitution to prohibit congressional authorization of federal court jurisdiction in several cases. See Alden v. Maine, I I9 S. Ct. at 2246; College Sav. Bank, 119 S. Ct. at 2233 ; Florida Prepaid Postsecondary Educ. Expense Bd., r ig S. Ct. at 2202 (1999); Seminole Tribe, $5 \times 7$ U.S. at 47. See generally Vicki C. Jackson, The Supreme Court, the Eleventh Amendment, and State Sovereign Immunity, 98 YALE L.J. I (I 988 ).

169 See MARTha MinOW, MAKING All THE Difference: Inclusion, EXclusion, AND AMERICAN LAW (I990); see also CAROL GILLIGAN, IN A DIFFERENT VOICE (I982). Illustrative of discussion drawing distinctions without claiming superiority is the exploration of differences between the jurisprudence of federal and state courts on the doctrine and purpose of separation of powers in Ellen A. Peters, Getting Away from the Federal Paradigm: Separation of Powers in State Courts, 8I MINN. L. REV. 1543 (1997).

170 See, e.g., Robert M. Cover, The Uses of Jurisdictional Redundancy: Interest, Ideology, and Innovation, 22 WM. \& MARY L. REV. 639 (1981) [hereinafter Cover, The Uses of Jurisdictional Redundancy]; Robert M. Cover \& T. Alexander Aleinikoff, Dialectical Federalism: Habeas Corpus and the Court, 86 YALE L.J. I035 (1977).

171 See Judith Resnik, Housekeeping: The Nature and Allocation of Work in Federal Trial Courts, 24 GA. L. REV. 909 (1990) [hereinafter Resnik, Nature and Allocation of Federal Trial Work] (discussing efforts by life-tenured judges to reallocate work to non-life-tenured judges). 
(b) Identity by Association. - Exactly when the federal judicial posture of its own cultural import began is not clear. ${ }^{172}$ Maybe a selfaggrandizing description existed early in the nineteenth century, and perhaps that kind of panache was a useful (if not necessary) attribute when striving for and fashioning a national identity. ${ }^{173}$ Further, since the first Judiciary Act, access to the federal courts through diversity jurisdiction has been tied to a minimum dollar amount, ${ }^{174}$ which arguably marks the federal courts as a more important venue by virtue of the economic value of the cases. ${ }^{175}$ Moreover, given a conception of federal jurisdiction as limited (in contrast to the general jurisdiction possessed by state courts), the subset of cases thus demarcated for the federal courts might always have been understood as consisting of special cases, and the courts in which they proceeded, therefore, as more important.

On the other hand, during the nineteenth century, Supreme Court Justices had no courthouse of their own ${ }^{176}$ and shared lodgings at

172 As Edward Purcell explains, although jurisdictional battles dot this country's history, their political and social import varies as the political meaning of vesting jurisdiction in either state or federal courts shifts. See EdWARd A. PURCELl, JR., Litigation AND INEQUality: Federal DIVERSITY JURISDICTION IN INDUSTRIAL AMERICA, 1870-1958, at vii-viii (I992) [hereinafter PURCELL, LITIGATION AND INEQUALITY]. This point is also a primary thesis of another Purcell book. See PURCELl, BRANDEIS AND THE PROGREsSIVE CONSTITUTION, supra note 19.

173 See, e.g., Stephen Botein, "What We Shall Meet Afterwards in Heaven": Judgeship as a Symbol for Modern American Lawyers, in PROFESSIONS AND PROFESSIONAL IDEOLOGIES IN AMERICA 49, 50-5 I (Gerald L. Geison ed., I983) (describing aspirations in the nineteenth century that identified the "ideal judge" with the "federal bench, preferably the Supreme Court"); see also Burt Neuborne, The Myth of Parity, 90 HARV. L. REV. I 105, $1124-27$ (1977) (arguing that identification of the federal courts as special helped federal judges enforce civil rights during the Ig6os and r97os).

174 See Act of Sept. 24, 1789, ch. 20, $\$ \S 1$ I-12, r Stat. 73, 78-80 (requiring that the matter in dispute exceed, "exclusive of costs, the sum or value of five hundred dollars," not only for diversity but also for cases in which "an alien is a party" or "the United States are plaintiffs, or petitioners," and permitting removal from state court by defendants in actions commenced by aliens or by defendants in diversity cases sued in the plaintiff's home state when the amount in controversy exceeds that value).

175 For discussion of the relationship between economic value and lawyer hierarchies, see JOHN P. HEINZ \& EDWARD O. LAUMANN, Chicago LaWYERS: THE SOCIAL STRUCTURE OF THE BaR 6I-9I (rev. ed. 1994). As Heinz and Laumann describe, fields in which lawyers "serve big business clients [are] at the top and those serving individual clients (especially clients from the lower socioeconomic groups) [are] at the bottom." Id. at 84-85.

176 For a brief discussion of the campaign for construction of a separate building for the Supreme Court, see Remarks of William Howard Taft, Chief Justice of the United States, 5 A.L.I. PROC. 133, $137-38$ (1927) and Address of William Howard Taft, Chief Justice of the United States, 7 A.L.I. PROC. 40, 40-4I (1929) [hereinafter 1929 Taft ALI Address]. The Cass Gilbert building opened in 1935, and the federal judicial administrative apparatus, when first created in 1939, was located therein. See Chief Justice William H. Rehnquist, Remarks at the 6oth Anniversary of the Administrative Office of the U.S. Courts I (May II, I999), available at http://www.uscourts.gov/ao6o/rehnquist.htm (visited July 29, 1999).

A half century later, with the opening of the Thurgood Marshall Federal Judiciary Building across from Union Station, the judiciary's administration gained space for its operations within 
boardinghouses; ${ }^{177}$ lower federal judges sometimes used state facilities or hotels as courts. ${ }^{178}$ As for compensation, some federal judges were paid less than their state court counterparts. For example, in the r930s, when petitioning on behalf of federal judges, New York lawyers argued: "In New York, for example, the justices of the state intermediate appellate court receive twice the salary of the circuit judges, and the judges of the court of first instance two and a half times the salary of the district judges. Federal judges assume at least an equal burden of work and in more diversified fields." 179

Commentators have also noted that during the I930s, the federal judiciary had a precarious sense of its own status and stature. ${ }^{180}$ As to job tenure, the sense of insecurity associated with state judicial elections may well have been less important in earlier eras. Although only three states have life-tenured judiciaries, ${ }^{181}$ judicial reelection was rela-

one building. See The Judiciary Office Building Development Act, Pub. L. No. 100-480 (Ig88); U.S. General Services Administration's Capital Investment Program: Hearings Before the Subcomm. on Pub. Bldg. and Econ. Dev. of the House Comm. on Transp. and Infrastructure, Iosth Cong. 317-328, (1997) (testimony of Herbert Franklin, Exec. Office of Architect of the Capitol) (describing "innovative financing" with a "public-private partnership," in which the judiciary tenants will be able to retire the indebtedness over 30 years and the "building will revert wholly to the United States government . . . without the payment even of one dollar").

177 See WHITE, supra note 115 , at 190-95 (discussing the effects of shared residences on the Court's decisions).

178 Beginning in the 1880 s, a wave of federal construction resulted in a growing number of federal buildings, which often included post offices, customs offices, and a floor of courtrooms. See CRAIG, supra note 35, at 104-68; Douglas P. Woodlock, Altending to the Nation's Business Within the Commonwealth: A Brief Historical Survey of the Anomalous Role of the United States District Court in the Massachusetts Judicial System, in I993 ANNUAL REPORT OF THE SUPREME JUDICIAL COURT IIISTORICAL SOCIETY 77, 86 (r994); Douglas P. Woodlock, The "Peculiar Embarrassment": An Architectural History of the Federal Courts in Massachusetts, 74 MASS. L. REV. 268, 272 ( 1989 ).

179 Letter from Chair of the Committee on Federal Legislation of the New York Bar Association (Apr. 10, 1939), in General Administrative Files, supra note 50, at Box 10 ("Judges - Accounts, Salaries"); see also Salaries of Judges, H.R. Rep. No. 69-232 (1926) at 5 ("Is our Federal judiciary - one of the three coordinate branches of the National Government - so contemptible and so unimportant that we shall refuse to pay them the reasonable compensation of an average good lawyer?"); S. DOC No. 7 I-69, at I-7 (I 930); WHITE, supra note I I5, at I63 n.29 (noting that the Chief Justice received a $\$ 5,000$ salary but that "[p]rominent lawyers such as William Pinkney and Daniel Webster earned as much as $\$ 17,000-20,000$ a year" $)$. This parallel remains true today, with some members of the private bar routinely receiving compensation many times in excess of that of members of the judiciary. For example, appellate judges in 2000 earn $\$ 149,900$, and district judges $\$ 141,300$, see Salary Rates Change in New Year, THIRD BRANCH, Dec. I999, at 3 [hereinafter Salary Rates], as compared to $\$ 622,000$, which was the average 1998 salary for partners at the 100 law firms with the largest gross incomes. See John E. Morris, Fining on All Cylinders, AM. LAW., July I999, at $71,72$.

180 See FISH, supra note 20, at 123-24 (reporting that many judges experienced a "loss of selfesteem and status" in the wake of the Depression and of the court-packing plan, and arguing that the creation of the AO was one way for judges to "clean their own house" (citation omitted)).

181 The three are Rhode Island, New Hampshire, and Massachusetts. See LYLE WARRICK, JUdICIAL SELECTION IN THE UNITED STATES: A COMPENDIUM OF PROVISIONS I9-34 tbls. I I-I4 (2d ed. 1993). 
tively routine until recently. ${ }^{182}$ Finally, the grand traditions of the common law are associated with great justices of state appellate courts, whose dominion has lessened during the second half of the twentieth century as congressional and state legislative codifications have circumscribed the role of the common law.

While dating the claims of cultural superiority is difficult, what is clear is that the rhetoric that federal courts were "too important" for certain kinds of cases appeared by the early part of the twentieth century. A central figure is (once again) William Howard Taft. In I9Io, he objected to the kinds of cases assigned to the Supreme Court. Taft argued for a docket of constitutional and statutory problems rather than of cases requiring construction of "particular forms of instruments, like indictments, or wills, or contracts," which were "not of general application or importance, [and] merely clog and burden the Court and render more difficult its higher function, which makes it so important a part of the framework of our Government."183

By the I920s, commentary began to suggest that Congress had erred when it gave federal courts "petty" criminal cases that risked turning federal courts into "police courts."184 Prohibition was one source of such views. ${ }^{185}$ According to Felix Frankfurter and James Landis, Prohibition was "largely but not exclusively responsible" for

\footnotetext{
182 Data from the 1980 sescribed a high rate of reelection of state court judges, but in recent years, high-profile electoral contests, coupled with changing benefit packages, may have helped to make employment in the federal system more desirable. See, e.g., SUSAN B. CARBON \& LARRY C. BeRKSON, JUdicial Retention Elections in THE UNITEd STATES app. B at 79 (American Judicature Society, I980) (reporting that, in 17 states surveyed, I3 judges out of 499 were not retained in elections during 1978 ).

183 I6 Messages and PAPERS OF The PRESIDENTS, 7431, 7523-24 (James D. Richardson ed., 1917), quoted in FRANKFURTER \& LANDIS, supra note 38, at 259 n.13. Frankfurter and Landis argued in the rg2os that the "business" of the Supreme Court had been transformed; they pressed for a reconception of its role from that of a common law court to one devoted to constitutional and statutory interpretation. See FRANKFURTER \& LANDIS, supra note 38, at 299-315 (arguing for the propriety of such a role through comparative analyses of the dockets of British and state supreme courts). They noted that the issue of "administrative law" (no longer "an exotic"), id. at 184 , raised the question of whether a "single system of courts" could respond or whether "specialized" courts for administrative issues would be required. Id. at I86.

184 See, e.g., Felix Frankfurter \& Thomas G. Corcoran, Petty Federal Offenses and the Constitutional Guaranty of Trial by Jury, 39 HARV. L. REV. 917, 980-82 (1926) (arguing that the Constitution does not require Article III judges or juries to determine "petty" criminal cases, yet disavowing taking a position on whether, as a matter of policy, Congress should alter its jurisdictional rules); Arthur E. Sutherland, Jr., Federal Police Courts, with Appendix Containing a Comparative Study of the Criminal Business in the United States Court for the District of Massachusetts in 1913 and 1924, MASS. L.Q., Aug. 1926, at 43, 46-48.

185 See Document 2, in Judicial Conference Meetings Records, supra note 50, at Box 2 (Sept. 1923-June I925), Folder 1924 Report and Minutes (recommending that agents within the Bureau of Prohibition be placed under the supervision of the Department of Justice so that "the attempted prosecution of trivial, futile and unimportant cases, which now crowd the dockets through the illadvised zeal and practical ignorance of the Prohibition Agents, can be avoided and only those cases taken up and pressed which will really deter the principal offenders").
} 
concern about a burdensome caseload and diminished status of the federal judiciary;186 in their view, "men of large scope and intellectual distinction - the kind of lawyers who alone ought to be put on the district courts - will refuse to be drawn into police court work."187

But how to position the federal courts and what distinctions to draw among courts was contested. During the same era, the Conference of Senior Judges rejected the ABA's suggestion that federal courts have special standards for admission of lawyers. ${ }^{188}$ Understanding the effort as designed to create a "class of preferential or preferred counsellors," and concerned that such distinctions could generate "an inimi-

186 FRANKFURTER \& LANDIS, supra note 38, at 251. The political goals of their book are examined by Edward Purcell, who argues that the authors wrote in a progressive, reformist tradition, and that they aspired to cabin the authority of the conservative Supreme Court and to transform the federal courts into a forum specializing in national law. See Edward A. Purcell, Jr., Reconsidering the Frankfurterian Paradigm: Reflections on Histories of Lower Federal Courts, 24 LAW \& SOC. INQUIRY 679, 683-88 (r999) [hereinafter Purcell, Histories of Lower Federal Courts]. For discussion of the role of the legal academy in promoting the prestige of the federal courts, see Purcell, BRandeis AND The Progressive Constitution, cited above in note 19, at 2 I6-22.

187 FRANKFURTER \& LANDIS, supra note 38, at $25 \mathrm{I}$; see also Purcell, Histories of Lower Federal Courts, supra note I86, at 706 (arguing that Frankfurter sought to "disarm an elite professional audience" by promoting a vision of federal judges that would result in keeping the federal judiciary small and less able to intrude on actions of states).

What effect Prohibition had on individuals considering or holding federal judgeships is unclear. Senator Kenneth McKellar elicited letters from federal district judges about the effects of "liquor cases" on their dockets; the responses were mixed, with some judges reporting that, despite such cases, their dockets were current, and with other judges complaining about volume. See 69 CONG. REC. 5542-48 (1926). Three members of the federal judiciary (William Squire Kenyon of the Eighth Circuit, Paul J. McCormick of the Southern District of California, and William I. Grubb of the Northern District of Alabama) were appointed by President Herbert Hoover to serve on the national commission considering Prohibition. See NATIONAL COMM'N ON LAW OBSERVANCE AND ENFORCEMENT, REPORT ON THE ENFORCEMENT OF THE PROHIBITION LAWS OF THE UNITED STATES (I93I) [hereinafter the WICKERSHAM REPORT, named for its chair]. The separate statements filed by each of the judges who served on the Commission did not focus on the role of the federal courts in enforcement of Prohibition. See id. at 115-16, 11737, 155-58. The Conference of Senior Judges also did not recommend to Congress that it either repeal - or continue - federal jurisdiction over such cases. See, e.g., ANNUAL REPORT OF THE ATTORNEY GFNERAL OF THE UNITED STATES FOR THE FISCAL YEAR I924 at ii; I93 IUDICIAL CONFERENCE REPORT, reprinted in ANNUAL REPORT OF THE ATTORNEY GENERAL OF THE UNITED STATES FOR THE FISCAL YEAR I932, at 8. The judiciary did, through these reports, note the problem of congestion and the need for more judges. Further, as a constitutional matter, the Supreme Court interpreted the Double Jeopardy Clause to include a dual sovereignty "exception," which permitted prosecutions for the same actions in both state and federal courts. See United States y. Lanza, 260 U.S. 377, 385 (I922). In Lanza, Chief Justice Taft, writing for the Court, explained: "in the absence of special provision by Congress, conviction and punishment in a state court under a state law for making, transporting and selling intoxicating liquors is not a bar to a prosecution in a court of the United States under the federal law for the same acts." Id.

188 See Transcript 3 (Sept. 27, 1926), in Judicial Conference Meetings Records, supra note 50, at Box 3 (June 1925-Sept. I926) (describing an ABA resolution recommending that lawyers practicing in the federal courts "be required to be better qualified and to have a keener appreciation of the dignity and responsibility requisite to the conduct of litigation in those courts"). 
cal feeling of irritation as between state courts and federal courts," the Conference deemed the proposal unwise. ${ }^{189}$

During the I920S and I930s, concerns about the quality of judges throughout the nation prompted reform efforts to professionalize judiciaries. ${ }^{190}$ Efforts to shore up the federal courts as a font of professional excellence should be read in that context as well as in conjunction with theories of labor addressing how certain forms of work come to be understood as deserving higher or lower status and pay. Social theorists have identified relevant factors to include the degree of task routinization, the perception of a certain activity as intellectually challenging, control over working conditions, and the demographics of the people identified as doing such work. ${ }^{191}$

Contemporary sociologists who have studied labor within the legal profession argue that "prestige within law is acquired by association."192 Their research concluded that lawyers representing large businesses had more prestige than those who represented individual clients, particularly those of low socioeconomic status. ${ }^{193}$ The claims of Taft, Frankfurter, and Landis map onto this grid but may also be a source of it. The interaction between structures of prestige at the bar and jurisdictional boundaries has yet to be fully excavated. ${ }^{194}$

(c) Identity by Distinction. - One variable in the developing sense of the federal courts as distinct from (and eventually as more important than) state courts is the creation in the r93os of nationwide federal rules of civil procedure. When discussing these rules above, ${ }^{195} \mathrm{my}$ focus was on the way in which they unified the practices of federal judges and provided a basis for development of norms of "good" judging. The relevance of the Federal Rules here is that they became one means by which federal courts began to differentiate themselves from state courts.

\footnotetext{
189 Id. at 229 (Judge Hough); see id.at 230 (Chief Justice Taft).

190 See supra pp. 943-49.

191 See EVERETT C. Hughes, Social Role and the Division of Labor, in THE SOCIOLOGICAL Eye: Selected PAPERS 304 (1971); see also EveretT C. Hughes, The Humble and the Proud: The Comparative Study of Occupations, in THE SOCIOLOGICAL EYE, supra, at 4I7. For discussion of the stratification of work in relationship to gender, see DOROTHY E. SMITH, THE EVERYDAY WORLD AS PROBLEMATIC: A FEMINIST SOCIOLOGY 107-08 (1987); and Heidi Hartmann, Capitalism, Patriarchy, and Job Segregation by Sex, I SIGNS 137 (1976). On the construction of kinds of cases and tasks as more prestigious within contemporary federal courts, see Resnik, $\mathrm{Na}$ ture and Allocation of Federal Trial Work, supra note 171.

192 HEINZ \& LAUMANN, supra note I75, at 135.

193 See id. at 6I-91.

194 See, e.g., Judith Resnik, "Naturally" Without Gender: Women, Jurisdiction, and the Federal Courts, 66 N.Y.U. L. REV. 1682, 1735-50 (199I) [hereinafter Resnik, Women, Jurisdiction, and the Federal Courts] (analyzing the assumptions that women reside in families and that family law belongs to the states, and countering with several aspects of federal law - welfare, tax, immigration, bankruptcy pension - that involve aspects of "family law" but are not so denominated).

195 See supra pp. 934-4I.
} 
With the promulgation of the Federal Rules of Civil Procedure in 1938 and the Supreme Court's decision of the same year in Erie Railroad Co. v. Tompkins, 196 the idea that federal and state courts were different because they had different procedures and controlled different arenas of law started to become embedded. Erie's prohibition on federal lawmaking in diversity cases constrained federal judges by placing them in the role of surrogate state judges, obliged to conform their rulings to those of the state judiciary. Add another event - collection within the federal courts of data that attempted to evaluate the time that each case took and identified "private cases" ("a considerable fraction of them brought under the jurisdiction based on diversity of citizenship") as a particular burden ${ }^{197}$ — and a sense of state cases as different and potentially uninteresting or burdensome for federal judges began to develop. 198

But the now familiar and essentializing response - that a subject matter was intrinsically "federal" as contrasted with "state" - was (in the 1940s) not yet an intuitive response for the U.S. Judicial Conference. Other cultural and political changes provided more of the context for that assumption to develop. During the I940s and I950s, habeas corpus and civil rights became the focus of Conference discussion and of Supreme Court adjudication. The era of Brown v. Board of Education and the beginning work of the Warren Court brought yet other forms of pressure to members of the federal judiciary. The idea of "state" as contrasted to "federal" functions began to be both formed and freighted as scenes of resistance by state officers to federal author-

196304 U.S. 64 (1938).

197 See Annual Report of the Director I (1948), in Judicial Conference Meetings Records, supra note 50, at Box 44 (Sept. 1947-Sept. 1947; Report of the Committee on Statistics, submitted by committee chair Charles Clark, at 9, in Judicial Conference Meetings Records, supra note 50, at Box 53 (Sept. I950-Sept. I950), Item 23, ("Private civil cases are a much more important factor in the caseload of an average judge than civil cases in which the government is a part."); see also ANNUAL REPORT OF THE DIRECTOR OF THE ADMINISTRATIVE OFFICE OF THE UNITED STATES COURTS IO5 (1955) ("[T]he average private case takes two to three-fold as much time on the part of the judge as a Government case.").

198 The creation by the American Law Institute in the I960s of a project on state and federal jurisdiction added another element. See Report of the Committee on Revision of the Laws, in JUDICIAL CONFERENCE RECORDS/AO ColleCTION, supra note 50, at Binder Mar. I964 (describing the day-long meeting with ALI members to discuss the project). As Herbert Wechsler's Foreword to the report from that project describes, Chief Justice Earl Warren, who addressed the ALI in 1959, suggested the project; he called upon the ALI to "undertake a special study" to define "the appropriate bases for the jurisdiction of federal and state courts." AMERICAN LAW INSTITUTE, STUDY OF THE DIVISION OF JURISDICTION BETWEEN STATE AND FEDERAL COURTS I (I 969 ). The Report proposed limitations on diversity jurisdiction by, for example, prohibiting an in-state plaintiff from using it; expansion of diversity jurisdiction for cases involving multiple parties from many states; and expansion of federal question jurisdiction through aboltion of the amount in controversy requirement for most cases arising under federal law. See id. at xii, 1-4. For criticism of this Report as lacking principles of allocation, see PURCELL, BRANDEIS AND THE PROGRESSIVE CONSTITUTION, cited above in note 19 , at $270-84$. 
ity made national news. Workload demands continued to grow, and (as noted above), the Judicial Conference began in the I950s to consider asking Congress not to enact certain proposed legislation.

Which bills to oppose and why became a focus of discussion within the Conference. For example, in 1954, the Conference reviewed a proposal pending before Congress that unfair labor practices be filed directly in the federal courts. 199 Some members wanted to oppose it for adding "substantially to the burden" of the courts, but others objected that under Conference procedures, district judges had first to be polled. ${ }^{200}$ The matter returned to the Conference in $1959 . .^{201}$ The archived report indicates that the committee charged by the Conference with providing an initial review did not propose disapproval but commented only about the proposed legislation as a source of docket congestion. ${ }^{202}$ Handwritten notes suggest that in discussion, the judges agreed that the Conference should register its opposition but were unsure about what rationale to offer. One judge stated that "overload" was the "only stand" to take, while another commented that the bill would alter the relationship between district courts and the Labor Board. The judges agreed that a subcommittee should consider what to say and return the following day. ${ }^{203}$ Thereafter, the subcommittee's proposed rationale was accepted, and the Conference explained its objection to the

prosecution and trial of unfair labor practice cases as private actions in the district courts on the ground that the proposed legislation would enlarge the jurisdiction of the district courts to embrace litigation or controversies of a type and character which the district courts are not organized or equipped to adjudicate, and for which there appears to be no historical precedent. ${ }^{204}$

199 See File no. 16, in Judicial Conference Meetings Records, supra note 50, at Box 70 (Sept. 1954-Sept. 1954).

200 Id.

201 See Action of the Judicial Conference of the United States at the Regular Annual Meeting 2 (Sept. 16-17, 1959) in JUDICIAL CONFERENCE RECORDS/AO COLLECTION, supra note 50, at Binder Sept. I 959 .

202 Item 7, Joint Report of the Committee on Court Administration and Revision of the Laws 3 (signed by Judges John Biggs, Jr. and Albert B. Maris, cochairs of the two committees), in JUDICIAL CONFERENCE RECORDS/AO COLlection, supra note 50, at Binder Sept. 1959 ("It is obvious that this bill, if enacted, would bring to the district courts a large amount of additional business particularly in the already congested courts in the large industrial centers. The Committee accordingly deems it proper to call the bill to the attention of the Conference but make no recommendation with respect to it.").

203 See Handwritten notes 32-33, 46 \& insert (Sept. 16, 1959), in JUDiCial CoNFERENCE RECORDS/AO COLLECTION, supra note 50, at Binder Sept. 1959 (exchange between Judges Maris and Sobeloff).

204 See id.; see also Attachment to a list of the Actions of the Judicial Conference of the United States at the Regular Annual Meeting (Sept. 16-17, 1959), in JUdiCial CONFERENCE RECORDS/AO COLLECTION, supra note 50, at Binder Sept. 1959. 
Here are the beginnings of efforts to identify district courts by (then illdefined) notions of sets of cases for which these courts were specially suited ${ }^{205}$ and to require Congress to justify decisions to add new causes of action. Thus, it was in the late I950s that the Judicial Conference began to suggest that particular kinds of lawsuits were (somehow) not appropriate for federal jurisdiction.

In this era, diversity jurisdiction was not considered by the Conference to be a primary target for restriction. Prompted by proposals from the Ninth Circuit and from members of Congress to limit or abolish diversity jurisdiction, the Conference formed a study committee, chaired by John Parker of the Fourth Circuit. The Committee concluded that "diversity jurisdiction has been recognized from the beginning as essential to the proper administration of justice under the system of dual sovereignty established by our Constitution"; and the Committee recommended support for diversity jurisdiction to provide the requisite "national outlook" to combat local prejudice. ${ }^{206}$

205 See also Report of Attorney General to (Sept. I9, 1955), in Judicial Conference Meetings Records, supra note 50, at Box 76 (Sept. I955-Sept. 1955) (statement of then-acting Attorney General William .Rogers) (discussing the burden on federal courts of litigation that could "best be handled by state or local courts").

Another example from this era is a proposal to register and enforce "support orders" in federal court. The Conference disapproved provisions of a bill that would have turned to federal courts for such enforcement but expressed no opinion on the proposed creation of a federal crime of traveling interstate to avoid such orders. The Committee reviewing the proposal was "convinced that there is need for some legislation ..., but that it is unnecessary and it would be unwise to provide for ... enforcement [in] Federal district courts," given that state courts had procedures for enforcement and many had adopted a uniform reciprocal enforcement act. 1957 JUDICIAL CONFERENCE REPORT 37. Subsequently, and on a variety of occasions thereafter, the Conference opposed proposals that would create either federal jurisdiction or causes of action related to the support rights of children. See, e.g., I977 JUDICIAL CONFERENCE REPORT, supra note 139 , at 53 (opposing a bill that would create a "federal right to every. unemancipated child to be supported by such child's parents or parent"); see also I 98 I JUDICIAL CONFERENCE REPORT 66-67. The Conference also objected to draft legislation ratifying the Hague Convention on the Civil Aspects of International Child Abduction to the extent that it provided "concurrent jurisdiction with state courts over litigation under the Convention." See I986 JUDICIAL CONFERENCE REPORT 12.

206 Report of the Committee on Venue and Jurisdiction 6, I1 (Mar. 12, 1951), in Judicial Conference Meetings Records, supra note 50, at Box 54 (March I95I-Sept. I95 I). Here again I am drawing a distinction between the federal judiciary's role in adjudication and its role in developing institutional policy positions, as well as between institutional efforts and individual efforts. As Purcell describes, in several instances judges attempted to use their opinion writing to influence legislative policy. See PURCELL, BRANDEIS AND THE PROGRessive ConstituTion, supra note I9, at 122-32 (discussing Justice Brandeis's efforts to fomulate rules constraining federal judges, his decisions in opposition to declaratory judgment "directed ... to the Senate," and his reliance on Frankfurter to press his views); see also id. at 144-47 (describing work by Brandeis, Frankfurter, and Henry Friendly to promote legislation to limit diversity jurisdiction). Further, Judge Parker himself had been an opponent of efforts in the I930s to restrict diversity jurisdiction. See id. at $8 \mathrm{I}$. Presumably, his selection as Chair of the r 950 s study committee reflected the past efforts to protect this form of federal court jurisdiction. 
Within that report, however, was the notion that the amount in controversy requirement, which already functioned as a filter in both diversity and in federal question jurisdiction cases, could be raised carefully, not so high as to convert the federal courts to courts "of big business" nor so low that those courts would "fritter away their time in the trial of petty controversies." 207 In I955, the Conference agreed to support an increase in the amount in controversy requirement, to $\$ 10,000$, for diversity filings. ${ }^{208}$

The Civil Rights movement of the Ig6os prompted more questions of how much the Judicial Conference, shifting into this mode of reviewing legislation with the metric of workload burdens, would register disapproval of jurisdictional provisions. While the idea that jurisdictional issues were "basic policy ...f for Congress to decide" remained for some judges, ${ }^{209}$ the Conference proffered its views on some bills plainly concerned with such basic policy. For example, in I 963 the Committee on Revision of the Laws reviewed pending civil rights legislation; the Committee noted that "questions of policy" were involved and advised that, while some additional cases would be brought under the public accommodations provisions, the Conference should inform Congress that the bill "will not impose an unreasonable burden on the Federal courts or unduly increase the amount of time now required by the courts to deal with civil rights cases."210 In I964, the Conference took a similar position towards the proposed Equal Employment Opportunity Act, ${ }^{211}$ and it opposed efforts to limit federal jurisdiction over school desegregation orders. ${ }^{212}$

207 Id. at 15.

208 I955 JUDICIAL CONFERENCE REPORT 80-81. For discussion of the Judicial Conference position of the late 1970 in favor of the abolition of diversity jurisdiction, see note 139, above.

209 See, e.g., Report of the Committee on Revision of the Laws ro (1960), in JUDICIAL CONFERENCE RECORDS/AO COLLECTION, supra note 50, at Binder Sept. I960 (discussing a proposal to withdraw limitations on injunctive relief in labor disputes, and commenting that "the passage of the bill would not materially increase the caseload of the courts but that the basic policy involved is one for Congress to decide"); see Report of the Committee on Revision of the Laws 8 (I961), in JUdicial CONFERENCE RECORDS/AO COLLECTION, supra note 50, at Binder Sept. I96i (concluding that jurisdictional provisions relating to districting posed a "question of public policy which is peculiarly for Congress to determine and as to which the Judicial Conference should not make any recommendation").

210 Report of the Committee on Revision of the Laws, submitted by Judge Maris, at 6-7 (1963), in JUDICIAL CONFERENCE RECORDS/AO COLLECTION, supra note 50, at Binder Sept. I963 (discussing S. I73I and H.R. 7152). Handwritten notes indicate "approved these amendments." Id.; see also 1963 JUDICIAL CONFERENCE REPORT 74.

211 See Report by Judge Biggs 23 (Feb. 27, I964), in JudicIal Conference Records/AO COLleCTION, supra note 50, at Binder Mar. I964, Committee on Court Administration (discussing S. 1937, 88th Sess. and noting that court review of agencies' enforcement decisions was not unusual); see also I964 JUDICIAL CONFERIENCE REPORT $12-13$.

212 Committee report re S. I683, at 25 , in JUDICIAL CONFERENCE RECORDS/AO COLLECTION, supra note 50, at Binder Mar. 1964 (including a pen-marked approval); see I964 JUDICIAL CONFERENCE REPORT 13. 
In the following decades, the Conference found some issues to involve questions of policy ${ }^{213}$ not within its ken and at other times entered such "policy" debates, although increasingly - as detailed above - to object to new causes of action through arguments about federal courts' special charter and import. The Conference has not only identified some cases as too small for federal jurisdiction, but has also argued that, because some cases were very big (specifically multi-state mass tort cases) and now denominated "complex," federal jurisdiction could properly be expanded to embrace them. ${ }^{214}$

I do not want to flatten out the nuances of jurisdictional arguments that occur within a democratic and federalist form of government. Arguments about stature and burden could be about only those issues, ${ }^{215}$ but questions about what kinds of cases to litigate in which courts also have a political valence, differently evaluated by changing sets of life-tenured judges and by litigants, of whom some sought the federal courts as a haven and others perceived these courts as a venue from which to escape. ${ }^{216}$ As state and federal legislatures or courts come to be perceived as friendly or hostile to certain groups or claims (pro-labor or anti-labor, pro-corporations or anti-corporations, pro-civil rights or anti-civil rights), granting or repealing federal jurisdiction provides a vehicle for advancing political goals about substantive reforms as well as for rewarding political allies and sanctioning opponents. ${ }^{217}$

213 See, e.g., 1983 JUdICIAL CONFERENCE REPORT 58-60 (objecting to some restrictions on jurisdiction and discussing amendments to the Age Discrimination in Employment Act as "matters of policy for Congress").

214 Both the FCSC REPORT and the LONG RANGe PLAN discuss federal court jurisdiction over certain large-scale, multi-party litigation. See FCSC REPORT, supra note II I, at 44 - 46; LONC RANGE PLAN, supra note III, at 91 n.I6. As the commentary in the LONG RANGE PLAN explains, in 1988 the Judicial Conference determined that, while otherwise "seeking to curtail or eliminate diversity jurisdiction, the Judicial Conference supports establishment of 'minimal' diversity criteria to allow federal court consolidation of multiple litigation involving personal injury or property damage arising out of a single event." Id.

215 See YACKLE, supra note 60 , at 48-49 (supporting the idea that federal judges should be an "elite corps" but arguing that increasing their numbers is unlikely to undermine prestige); see also Rory K. Little, Myths and Principles of Federalization, 46 HASTINGS L.J. 1029, 1055-61 (1995) (discussing differing premises underlying the debate about federal judicial elitism).

216 See Purcell, Histories of Lower Federal Courts, supra note 186, at 698-706 (discussing efforts by progressives to "minimize the opportunities for the federal judiciary to restrict or invalidate progressive state actions").

217 See, e.g., FRANRFuRTER \& LANDIS, supra note 38, at $94-96$ (describing the House as supporting limits on removal jurisdiction that the Senate opposed, in part because the federal courts were understood as preferable fora for corporate actors); see also PURCELL, LITIGATION AND INEQUALITY, supra note 172 , at 200-16 (discussing insurance companies' preferences for federal courts). Another example comes from the 1930s, when progressives fashioned administrative agencies as a means of escape from the federal judiciary, perceived to be hostile to small claims and workers' rights. See, e.g., Note, Crowell v. Benson: Inquiries and Conjectures, 46 HARV. L. REV. 478 (1933) (discussing the degree to which the ruling, authorizing federal court review of 
Protesting federal jurisdiction can also be a way to object to an underlying legal norm (in the context of Prohibition, for example, making the sale of alcohol illegal) or to further a norm (such as enforcing civil rights). Further, jurisdictional arguments can, in a federalist government, also be premised on an objection to the fact of federal - rather than state - enforcement of that norm. Those two issues intersect: enlisting the federal government to police activities may stem from the reluctance of states to do so, and state reluctance may, in turn, be based on underlying disagreements about whether a given activity should be unlawful. Federal jurisdictional discussions thus became a means by which to enact conflict about legal rules.

Just as assessing intent requires elaboration, so does evaluating impact. What effects have the decades of claims about federal judicial distinctiveness had? In terms of jurisdiction, the judiciary's track record of lobbying success in Congress is mixed. Congress has revised the diversity statute to narrow its reach but has not made the kinds of dramatic exclusions advocated by the federal judiciary, nor has it stopped enacting new federal rights when political claimants successfully coalesce. ${ }^{218}$ Yet the discourse of the importance of federal courts has penetrated legal and popular culture, as demonstrated by the place of the federal courts in law schools' course offerings ${ }^{219}$ and the atten-

"jurisdictional facts" would undercut the efficacy of administrative agencies); Comment, Judicial Review of Administrative Findings - Crowell v. Benson, 4I YALE L.J. 1037 (1932).

218 See supra note 139, (discussing Judicial Conference endorsement of the abolititon of most of diversity jurisdiction); $A O$ r 998 Statute List, supra note 1 Io (listing causes of action enacted since 1974).

219 Legal education not only reflects but contributes substantially to the primacy of federal courts. Here Felix Frankfurter (again) comes to the fore; after the 1928 book (with James Landis) on the federal courts, Frankfurter joined with Wilber Katz in writing a book to teach students about the federal courts. See Felix FrankfurTer \& Wilber G. KaTZ, Cases and OTHER AUTHORITIES ON FEDERAL JURISDICTION AND PROCEDURE (1931). (The I937 edition was coauthored by Harry Shulman.) Through such work, courses on the federal courts began to make their way into the curriculum. The promulgation in 1938 of the Federal Rules of Civil Procedure and parallel efforts to promote the teaching of the Rules aided in focusing segments of the legal academy on the federal courts. See generally James William Moore, The Place of the New Federal Rules in the Law School Curriculum, 27 GEO. L.J. $88_{4}$ (1939).

In 1954, the mantle passed to Henry Hart and Herbert Wechsler through their book THE FEDERAL COURTS AND THE FEDERAL SYSTEM (1954) (dedicated to Felix Frankfurter); they were joined over time by Paul Mishkin, Paul Bator, Daniel Shapiro, Daniel Meltzer, and Richard Fallon. See HART \& WECHSLER, supra note 96 . The legal academy has debated the place of the 1954 book's conception in contemporary teaching. See generally Akhil Reed Amar, Law Story, I02 HARV. L. REV. 688 (1989) (reviewing the third edition); Richard H. Fallon, Jr., The Ideologies of Federal Courts Law, 74 VA. L. REv. 14I (1988) [hereinafter Fallon, Ideologies] (arguing that two competing conceptions, nationalist and federalist, exist within the doctrinal and intellectual approaches); Richard H. Fallon, Jr., Reflections on the Hart and Wechsler Paradigm, 47 VAND. L. REV. 953 (I994) (discussing the conceptual premises about the rule of law and legal process); Mary Brigid McManamon, Challenging the Hart and Wechsler Paradigm, 27 CONN. L. REV. 833 (1995) (reviewing LOUISE WEINBERG, FEDERAL COURTS: CASES AND COMMENTS ON JUDICIAL FEDERALISM AND JUdICIAL POWER (1994)); Judith Resnik, Dependent Sovereigns: Indian Tribes, 
tion paid to the federal courts by the media and the legal establishment. 220 The American Bar Association (ABA) has adopted the Judicial Conference's negative attitude toward "federalization" of criminal law, 221 explained as necessary to avoid "diminish[ing] the separate and distinctive role played by federal courts."222 The claim of distinction has also become part of popular and legal understandings; during the last forty years, the phrase "don't make a federal case out of it" has entered into the lexicon.223 Opinions from both state and federal judges now castigate litigants for attempting to use federal statutes to turn "state" actions into "federal" lawsuits. ${ }^{224}$

States, and the Federal Courts, 56 U. CHI. L. REV. 671, 680-86 (1989) (detailing the creation of this jurisprudential and academic field and its analytic foci).

220 See Purcell, Histories of Lower Federal Courts, supra note 186, at 696-97 (describing the "powerful image" projected by the federal courts and arguing that claims of the distinctive jurisprudential mission had "triumphed" such that few judges or lawyers question them).

221 See TASK Force on the Federalization OF CRIMINAL LaW, AMERICAN BAR Ass'N, The FEDERALization OF CRIMINAL LAW, 26-5 I (James A. Strazzella rptr., I998). This report, from the ABA's Criminal Justice Section, discussed the "adverse effects of federalization." In 1999, the House of Delegates approved the recommendation that Congress be urged to "adhere to principles" to limit "inappropriate federalization of criminal law" as detailed in the volume. AMERICAN BAR ASS'N, REPORTS WITH RECOMMENDATIONS TO THE HOUSE OF DELEGATES (I999) [hereinafter ABA RECOMMENDATIONS] (describing the principles as including creating federal crimes "only when a clear federal interest is implicated" and state remedies are inadequate; considering "Inechanisms" such as "impact statements" to assist in analyzing proposed legislation; and providing "sunset provisions" in some statutes).

222 TASK FORCE ON THE FEDERALIZATION OF CRIMINAL LAW, supra note $22 \mathrm{I}$, at 35 . The monograph also criticizes "permitting essentially state and local offenses to swell federal court caseloads" and thereby to create pressure for "the number of federal judgeships [to] grow to an unacceptable size [such that] the federal courts will function far less efficiently and far less effectively." Id. at 37; $c$. Little, supra note 215 (providing a history of the overlapping jurisdictional grants and questioning claims of overload).

223 See ERIC PARTRIDGe, A Dictionary of Catch Phrases 52 (1977) (defining the phrase to mean, colloquially, "Don't exaggerate the importance of something. Don't exaggerate the seriousness of my action - e.g., of a mistaken judgment: US: since c. I950"); see also HAROLD WENTWORTH \& STUART BERG FLEXNER, DICTIONARY OF AMERICAN SLANG 179 (citing use in I957 and similarly defining the phrase as "[t]o overemphasize the importance of something").

A review of data-based decisions indicates that the phrase was first used in opinions in the I 9605 . For example, a Florida judge explained that a "person who suffers a major upset over a minor grievance is admonished not to 'make a federal case out of it." Reynolds v. State, 224 So. 2d 769, 769 (Fla. Dist. Ct. App. 1969) (upholding a prisoner's claim of access to Florida postconviction remedies to review convictions obtained allegedly in violation of Gideon $v$. Wainweright). Westlaw and Lexis data bases of cases from both before and after 1944 include 79 cases employing the phrase, 63 from the federal courts and 16 from the state courts. See Memorandum of Matthew Kutcher (Apr. 5, 1999) (on file with the Harvard Law School Library); see also Frederick Bernays Wienter, Wanna Make a Federal Case out of It?, 48 A.B.A. J. 59 (1962) (speculating on the origins of the phrase).

224 See, e.g., Braden v. Texas A. \& M. Univ. System, 636 F.2d 90, 93 (5th Cir. I 98I) (per curiam) ("Just as Section 1983 does not create a cause of action for every state-action tort, it does not make a federal case out of every breach of contract by a state agency." (citations omitted)); Bruns v. Ledbetter, 58,3 F. Supp. 1050, 1055 (S.D. Cal. I984) ("If read as myopically as plaintiffs suggest, RICO would literally make a federal case out of nearly every instance of business fraud." "; Bates v. Provident Consumer Discount Co., 493 F. Supp. 605, 607-08 (E.D. Pa. 1979) ("Congress did not 
And, once again, understanding effects is complex. Discussions of social status may reflect anxiety, rather than confidence, about claimed authority. The discourse around the federal judiciary's own import could be evidence of a judiciary worrying about its centrality. The development of the jurisprudence of the federal courts in the last fifty years has been influenced by Felix Frankfurter, James Landis, Henry Hart, and Herbert Wechsler; much of the emphasis has been on what Hart called the "interstitial" nature of federal law. 225 Although Felix Frankfurter and James Landis argued that "men of large scope and intellectual distinction"226 would not want to work as federal judges if assigned low-level criminal cases (and his claims are echoed in current commentary about the risk of federal courts becoming "drug courts"227), perhaps the problem stems not from "ordinary" cases but from doctrinal limits that constrict the job of federal judging.

Since Erie, ${ }^{228}$ the federal judiciary has been awkwardly selfconscious about its limited license to make common law. ${ }^{229}$ The restrictions on federal common law adjudication put federal judges in a defensive posture, required to compress much of their decisionmaking into categories called constitutional and statutory, to avoid the charge of straying too far from their mandate. Meanwhile, state judges - especially those sitting on the highest courts - do frankly generative

intend by the Truth in Lending Act to make a federal case out of a lawful charge ... by a money lender...." (citation omitted)).

225 Hart's I 953 statement in the casebook is reprinted in the I996 edition of HART \& WECHSLER. See HART \& WECHSLER, supra note 96, at 521 . For discussion of the distinctions between the attitudes of Frankfurter and those of Hart towards the federal courts, see PURCELL, BRANDEIS AND THE PROGRESSIVE CONSTITUTION, cited above in note 19, at 229-57, which also discusses Hart's promotion of federal court power, coupled with his ambivalence about the forms of deployment by the Warren Court.

226 FRANKFURTER \& LANDIS, supra note 38, at $25 \mathrm{I}$; see supra note 187.

227 See e.g., Kenneth Conboy, Editorial, Trouble in Foley Square, N.Y. TIMES, Dec. 27, 1993, at AI 7 ; see also Little, supra note 215 , at 1037 , $1055-61$.

228 Erie Railroad Co. v. Tompkins, 304 U.S. 64 (1938); see PURCELL, LITIGATION AND INEQUALITY, supra note 172 , at 224-43 (discussing the effects of the Erie ruling on litigation decisions); see also Larry Lessig, Erie Effects of Volume 1 Io: An Essay on Context in Interpretive Theory, I Io HARV. L. REV. 1785 (1997) (discussing Erie's status as a conceptual placeholder).

229 See Atherton v. FDIC, 5 I9 U.S. 2 I3, 226 (1997) (rejecting efforts by the FDIC to have federal common law standards govern the standard of care for officials at federally insured saving institutions, and reviewing the very narrow boundaries of permissible common law development by federal courts). How limited federal courts are and should be from common law decisionmaking is an issue deeply contested; for insightful analyses, refer to PURCELL, BRANDEIS AND The PROGRessive CONSTITUTION, cited above in note 19, at 302-05; Richard H. Fallon, Jr. \& Daniel J. Meltzer, New Law, Non-Retroactivity, and Constitutional Remedies, I04 HARV. L. REV. 173 I (1991); Larry Kramer, The Lawmaking Power of the Federal Courts, 12 PACE L. REV. 263 (1992); Daniel J. Meltzer, State Court Forfeitures of Federal Rights, 99 HARV. L. REV. I 28 (I986); Martha A. Field, Sources of Law: The Scope of Federal Common Law, 99 HARV. L. REV. 88I (I986); Henry P. Monaghan, The Supreme Court, 1974 Term - Foreword: Constitutional Common Law, 89 HARV. L. REV. I (1975); and Peter L. Strauss, On Resegregating the Worlds of Statute and Common Law, 1994 SUP. CT. REV. 429. 
work in law development, resulting in at least anecdotal accounts by individuals who have held both state and federal judicial positions that they often had more power and more interesting work when they were on the state bench.

(d) The Quantities and Kinds of Federal Judges. - In addition to participating in developing a vision of the federal courts as meriting a distinctive and important docket, the Judicial Conference also helped, during the second half of the twentieth century, to increase the number of life-tenured judges and to create federal judgeships without life tenure. I turn now to examine the Conference's approaches to the question of the numbers and kinds of judgeships.

Requests for new judgeships lace the century, as do Conference discussions about when, how, and how many to propose. ${ }^{230}$ In the I980s, some Article III judges urged the Judicial Conference to oppose commissioning too many life-tenured federal judges and to consider decommissioning some as well. Given complaints about a workload in excess of capacity, opposition to more judgeships requires exploration. As detailed below, arguments for retrenchment derive from a mixture of attitudes about the kinds of work appropriate for the federal judiciary and the tasks judging entails, about the desirability of developing hierarchies of judges within and without the Third Branch, and about congressional reluctance to fund fully a life-tenured judiciary sufficient for the needs of the administrative state.

Seeking judgeships has always been a self-conscious act for the Judicial Conference. ${ }^{231}$ The focus of much of the early efforts at improving data collection was on how to verify the need (to itself and to Congress) for new judgeships and to develop means by which to "weight" cases and thereby abandon reliance on crude equations that depended on the number of pending cases to support requests for new judgeships. ${ }^{232}$ Aware of the potentially endless impulse to enlarge

230 See FISH, supra note 20 , at $262-63$ (describing mid-century debates on "manpower"). For examples of requests for additional personnel, see ANNUAL REPORT OF THE DIRECTOR OF THE ADMINISTRATIVE OFFICE OF THE UNITED STATES COURTS $6 \$-69$ (1958), and note 129 (discussing the pending request for judgeships).

231 See, e.g., 1932 Report 5, in Judicial Conference Meetings Records, supra note 50, at Box 8 (1932-1933) (stating that "the Conference fully realizes the difficulties growing out of economic conditions and the imperative necessity for retrenchment in government expenses" but "deems it to be its duty to set forth the actual needs of the judicial department," specifically more district court judges). The Conference also sought to control the frequency of judgeship requests. See Minutes of meeting of the Statistics Committee (June 10, 1952), in Judicial Conference Meetings Records, supra note 50, at Box 9 ("Inclusion in committee report of statement as to important role which the Conference has in prevention of the creation of unnecessary judgeships, as well as in recommending those needed .... .").

232 See Report on the Study of Relative Weight to be Given to Different Types of Cases, in Judicial Conference Meetings Records, supra note 50, at Box 43 (Sept. 1947-Sept. 1947) (prepared 
one's own ranks, of congressional rejections of some of its requests, ${ }^{233}$ of the possibility that asking too often could draw unwanted attention to the courts, ${ }^{234}$ and of a relationship between electoral cycles and the creation of new judgeships, the Judicial Conference developed a practice of surveying judgeship needs at set intervals and relying on a presumption against asking for judgeships in the interim except in exigent situations. ${ }^{235}$

A shift has occurred during the last few decades, as debate has grown within the judiciary about whether and how to increase its numbers. During the I 980 s and r 990 s, several Article III judges argued against much expansion; they relied on an amalgam of claims about maintaining excellence through selectivity and about containing the numbers of conflicting decisions by lowering the output of judges. ${ }^{236}$ Intuition (the idea that the federal judiciary has a "natural"

for the 1947 fall session by Will Shafroth of the AO); Report of the Committee on Statistics, in Judicial Conference Meetings Records, supra note 50, at Box 46 (Sept. 1948-Mar. 1949).

233 See, e.g., Transcript of 1934 Meeting 3 , in Judicial Conference Meetings Records, supra note 50, at Box 10 (1933-34). Attorney General Homer Cummings reported that "we were very unsuccessful in the matter of making temporary judgeships permanent and in securing additional judgeships." Id.; see Agenda memo for the I936 Meeting of the Conference of Senior Judges 4-5, in Judicial Conference Meetings Records, supra note 50, at Box $\mathrm{I}_{3}$ (including, as new business, renewing requests for judgeships).

234 See Transcript of 1937 Meeting 17, 146-47, in Judicial Conference Meetings Records, supra note 50, at Box 13. Chief Justice Hughes read a letter from Senator Henry Ashurst discussing a congressional subcommittee's review of the judiciary, noted that close scrutiny of the courts was anticipated, and discussed "helter-skelter" requests for judgeships as a part of what prompted interest in more comprehensive review. See id.

235 See Report of the Committee on Judicial Statistics 3-8, in JUdICIAL CONFERENCE RECORDS/AO COLLECTION, supra note 50, at Binder Sept. I955, Vol. II, item 16 (discussing the need to create standardized procedure by which to assess workload demands and to make requests). The regularization of such a process was also a means by which to shift authority away from the assessments of individual circuits and toward the Conference. See also 1970 JUDICIAL CONFERENCE REPORT $\mathrm{I}_{3}$ (describing the practice of doing surveys at intervals on judicial needs and refusing to endorse requests for judgeships outside this cycle unless emergency conditions were established). The Conference switched from a four-year to a two-year cycle in 1977 - in part because of the lag time from requests to approval. See 1977 JUDICIAL CONFERENCE REPORT, supra note 139 , at 6 .

In 1998, the Chief Justice appointed the "Judicial Officers Resources Working Group," a committee composed of chairs of Judicial Conference committees, created "in partial response to the concerns" of Senators Orrin G. Hatch and Charles E. Grassley that the judiciary be "as vigorous in its standards in filling judicial vacancies as it is to justify creating new judgeships." Can the Federal Courts Cope Without More Judges?, THIRD BRANCH, Nov. 1999, at 6 (discussing efforts to share information on efficient case processing, to rely on visiting judges, and to identify courts with heavy workloads).

236 A summary is provided in GoRDON BERMANT, WILLIAM W SCHWARZER, EDWARD SUSSMAN \& RUSSELl R. WHEEler, IMPOSING a MORATORIUM ON THE NUMBER OF FEDERAL JUDGES: ANALYSIS OF ARGUMENTS AND IMPLICATIONS 26-54 (Federal Judicial Center 1993). Arguments for a small judiciary could be made in service of an array of political views. See Purcell, Histories of Lower Federal Courts, supra note 186, at 688 n.24 ("[T]he elitist Frankfurterian premise was an element in his progressive political agenda aimed at limiting the size and reach of 
size) has also been offered as the basis for constraint. Illustrative is the statement of Richard Posner, who claimed that as the federal judiciary was approaching rooo judges, it was reaching the "natural limits of expansion." ${ }^{237}$ Another proponent suggested a cap of 1000 judges, ${ }^{238}$ while other judges objected to such limitations. ${ }^{239}$ Jack Weinstein, for example, countered that advocates of a small judiciary were promoting a false sense of "emergency" in support of closing down access and that in "a population of a quarter of a billion people a federal judiciary of less than a thousand is not too large." ${ }^{240}$ During those same decades, the number of 1000 was eclipsed in practice. About I Ioo life-tenured and another 900 bankruptcy and magistrate judges worked in 1998 to respond to the requests for adjudication within the Article III judiciary. ${ }^{241}$

a conservative national judiciary. It seems no surprise that in the late twentieth century political 'conservatives' attacking 'liberal' federal courts have learned to use the same arguments.").

237 Richard A. Posner, Coping with the Caseload: A Comment on Magistrates and Masters, 137 U. PA. L. REV. 2215, 2216 (1989). In the 1996 version of his book, THE FEDERAL CouRTS: CHALLENGE AND REFORM, Posner argued that large numbers of judges undermine appellate court function but that, if the judiciary were to double in size, "the sky would not fall." POSNER, THE FEDERAL COURTS: CHALLENGE AND REFORM, supra note 60, at 132-39.

238 See Jon O. Newman, r,000 Judges - The Limit for an Effective Federal Judiciary, 76 JUDICATURE 137,187 (1993) (using the number to bring attention to the need to hold "[t]he line"); see also William H. Rehnquist, The 1997 Year-End Report of the Federal Judiciary, THIRD BRANCH, Jan. 1998, at 3 [hereinafter Rehnquist, 1997 Year-End Report] ("[A] bigger federal Judiciary is not necessarily a part of a solution for every public-policy question."); William $\mathbf{H}$. Rehnquist, Chief Justice's I $99 \mathrm{I}$ Year-End Report on the Federal Judiciary, THIRD BRANCH, Jan. 1992, at I, 2 [hereinafter Rehnquist, 199I Year-End Report] ("[A] federal judiciary rising above 1,000 members will be of lesser quality and could be dominated by a bureaucracy of ancillary personnel."); see also Gerold Bard Tjoflat, More Judges, Less Justice, A.B.A. J., July 1993, at 70.

239 See, e.g., Stephen Reinhardt, Too Fere Judges, Too Many Cases, A.B.A. J., Jan. I993, at 52; Mary M. Schroeder, Statement submitted to the Commission on Structural Alternatives for the Federal Courts of Appeals (May 29, 1998) (objecting to efforts to reduce the size of the Ninth Circuit) (on file with the author); Jack B. Weinstein, Keeping the Federal Courts Open for All Our Peoples, Statement before the Federal Courts Study Committee (Jan. 30, 1990) ("The district courts can be increased in size.") (on file with the author).

240 Weinstein, supra note 239 , at 1 .

241 The actual number of life-tenured judges could be calculated differently, depending upon whether one counts judges who have taken senior status, many of whom carry full or almost full caseloads. As of January I, I998, the number of authorized life-tenured judgeships at the district court level was 642 (including 10 "temporary" judgeships); the number of senior status judges was 337; the number of authorized judgeships at the appellate level was 179 ; the number of senior judgeships was; 91. See Administrative Office of the U.S. Courts, Justices and Judges of the United States (Jan. I, 1998) [hereinafter Justices and Judges]; see also I998 OPTIMAL UTILIZATION, supra note 95 at 10.

If counting both active and senior judges, and if all authorized judgeships were filled, then 1249 federal life-tenured judges worked in 1997. Even if a vacancy rate left 100 judgeships to fill (as of January I, 1998, 62 district and 23 appellate judgeships were open), more than 1100 lifetenured judges worked. See Justices and Judges, supra. In addition, 326 full-time bankruptcy judges (authorized positions as of 1998 ) and 429 full-time magistrate judges (authorized positions) provided another 755 judges, comprising a workforce, within the Third Branch, of more than 1850 judges. See id. 
Within the judiciary, conflict about the question remains. In 1997, a chief circuit judge testified (on his own behalf) before Congress that a vacant judgeship on his court should not be filled, and he pressed his campaign for fewer judges and less jurisdiction. ${ }^{242}$ The Judicial Conference has tried to fashion a compromise ${ }^{243}$ by adopting a position of limited growth in life-tenured positions (seeking some, but not all, of the new judgeships proposed from within its ranks ${ }^{244}$ ) while also reevaluating authorized judgeships with an eye to proposing that some be decommissioned. ${ }^{245}$ In I997, the Judicial Conference asked the District of Massachusetts to justify the preservation of one of its authorized judgeships. (Judges of that district responded that judging capacity did not exceed demand in Massachusetts. ${ }^{246}$ )

While divided about how much to expand the ranks of life-tenured judges, enthusiasm for additional judging by non-life tenured judges has grown. Proposals to deploy non-life tenured decisionmakers (many

242 See Considering the Appropriate Allocation of Judgeships in the U.S. Courts of Appeals for Fourth, Fifth, and Eleventh Circuits: Hearings Before the Subcomm. on Admin. Oversight and the Courts of the Senate Comm. on the Judiciary, rosth Cong. I4 I6 (1997) [hereinafter Judgeship Allocation Hearings] (statement of J. Harvie Wilkinson, III) [hereinafter Statement of Judge Wilkinson] (arguing against filling vacancies on the Fourth Circuit and noting that his remarks "represent[ed] his own views," with which some of his colleagues disagreed); see also J. Harvie Wilkinson III, Editorial, We Don't Need More Federal Judges, Wall ST. J., Feb. 9, I998, at Ar9; J. Harvie Wilkinson III, The Drawbacks of Growth in the Federal Judiciary, 43 EMORY L.J. I147, 1147-48 (1994). Cf. Judgeship Allocation Hearings, supra, at ig (statement of Sam J. Ervin III) (requesting that the two vacancies on the circuit be filled).

243 See LONG RANGE PLAN, supra note III, at 98 ("Recommendation 15: The growth of the Article III judiciary should be carefully controlled so that the creation of new judgeships, while not subject to a numerical ceiling, is limited to that number necessary to exercise federal court jurisdiction."). The commentary explains that while a cap might "in theory" be helpful, it would not "allow the federal courts to mairitain both the excellence for which they are known and appropriate access to federal remedies." Id. at 99; see also id. at 78 (describing as "nightmarish" scenarios that would require 4000 or more federal judges to handle the docket).

244 See supra note 129; see also 1993 JUDICIAL CONFERENCE REPORT I6 (declining to endorse the Ninth Circuit's request for ro additional judgeships and referring the issue to the Long Range Planning Committee).

245 See March 1999 JUDICIAL CONFERENCE REPORT i8 (draft) (on file with the Harvard Law School Library). The Report states:

In March 1996, the Judicial Conference approved a recommendation . . . to include in biennial district judgeship surveys a review of courts where it may be appropriate to recommend eliminating judgeships or leaving a vacant judgeship unfilled . . . A process for such a review in the district courts was approved ... in March $1997 \ldots$ and a similar mechanism was approved for the courts of appeals in March 1998 . . . Based on the findings ...., and after opportunity for additional input from affected courts and judicial councils, [the Conference approved recommendations that] the Judicial Conference advise the President and the Senate that any single or existing or future vacancy not be filled in the following courts: District of Delaware; District Court of the District of Columbia; District of Wyoming, and the Southern District of West Virginia ...."

Id; see also 1996 JUDICIAL CONFERENCE REPORT, supra note 9, at 24.

246 See Letter from Joseph L. Tauro, Chief Judge, to Patrick Conmy, Chair of the Subcomm. on Judicial Statistics, Judicial Conference (Apr. 8, 1998) (signed by all Article III Judges in the U.S. District Court of Massachusetts) (on file with the Harvard Law School Library). 
of whom were not called "judges" until the last few decades) have spanned United States history. The first such officials were "United States Commissioners," who worked in the nineteenth and twentieth centuries on a fee-for-service basis and provided some first-tier decisionmaking, particularly in the territories. ${ }^{247}$ During the first half of the twentieth century, proposals were forwarded to expand the role for commissioners and other auxiliary adjudicators ${ }^{248}$ - for example, to respond to the demands of Prohibition. ${ }^{249}$

Yet life-tenured judges also had a conception that certain aspects of their work could not be reassigned. Both in discussions within committees of the Judicial Conference ${ }^{250}$ and in decisions of the Supreme Court, ${ }^{251}$ judges and justices insisted upon role specificity and argued that delegation was unwise, if not unconstitutional. For example, in I944, a committee of the Conference proposed legislation authorizing district courts to delegate to commissioners the authority to accept

247 See Act of Feb. 20, 1812, ch. 25, \& I, 2 Stat. 679, 679-82 (creating commissioners and authorizing them to receive bail and affidavits). Thereafter, commissioners' responsibilities were expanded to include dealing with preliminary proceedings in criminal cases (such as arrest, bail, and the transfer of defendants), as well as doing limited work in admiralty and in civil cases (such as administering oaths). Although commissioners were "officers" of the court and engaged in forms of adjudicatory activity, they were understood to be working under the direction of judges and not to be judges. See Todd v. United States, I58 U.S. 278, 283 (1895).

248 See, e.g., 1929 Taft ALI Address, supra note 176, at 42 (describing workers' compensation acts and arguing that the federal courts needed similar provisions to deal with railroad and other federal employee claims).

249 As Attorney General William Mitchell explained in his letter introducing the WICKERSHAM REPORT, see supra note 187: "[using] United States commissioners for disposing of a large number of criminal cases ... speed[s] the work and reliev[es] the Federal judges of burdensome details. There are some constitutional questions involved, but in my opinion these do not present insurmountable difficulties, and the validity of the proposal is supported by ... eminent jurists." Introductory letter from Attorney General William D. Mitchell to the President (Jan. 13, 1930), reprinted in Hearings, To Enlarge the Powers of United States Commissioners and to Amend Title 2 of the National Prohibition Act: Hearings before the House Comm. on the Judiciary, 7 1st Cong. 3 (1930). Discussion of an enlarged role for U.S. commissioners was dropped by the Conference after questions about the constitutionality of such a role emerged. See FISH, supra note 20, at 6869. The Conference of Senior Judges did recommend that the Justice Department, rather than the Treasury Department, screen cases for filing in federal court. See id. at 67-68.

250 The Committee described its proposal to shift initial factfinding in cases involving lost seamen's wages to the Coast Guard and explained:

[T]he proposal is in no sense one that relieves the admiralty courts of their constitutional function to adjudicate the rights of all claimants with respect to the effects and wages of both deceased and deserting seaman. The proposal is merely to relieve these courts of making the initial finding, with the right at all times for any claimant to contest such finding in the admiralty court.

Report of the Committee on Seaman Wages 19 (circulated Jan. 2, I95I), in Judicial Conference Committee Records, supra note 50, at Box 25 (Seaman Wages to Speeches); see also S. 326I, 82d Cong. $\$ 4542-4545$ (1952) (providing for such delegation); 98 CoNG. REC. 6196-97 (1952) (statement of Sen. McCarren) (describing the "very eminent sponsorship" of the proposed bill and attaching Henry Chandler's letter explaining that the judges proposed the bill because of the administrative nature of the work related to seamen and the impossibility of factfinding).

251 See, e.g., Crowell v. Benson, 285 U.S. 22, 56 (1932). 
pleas and sentence petty offenders. The committee explained that its recommendation was predicated on the view that "the power to impose sentence is not a part of the inherent constitutional judicial power, but may be conferred by the Congress on administrative officers." 252

Suggestions for use of alternative decisionmakers increased during the following decades. In $195^{6}$, a Judicial Conference committee proposed using special masters for pre-trials in protracted cases. ${ }^{253}$ In 1958, the idea of using a "pre-trial examiner" for personal injury cases in the district court of the District of Columbia met with approval; ${ }^{254}$ in I960, the Conference authorized such a position in the Southern District of New York ${ }^{255}$ and then attempted to gauge its effects. By I 964, a committee within the Judicial Conference described how judges could be "relieved of many non-judicial functions in connection with pretrial proceedings and ... enabled thereby to devote themselves strictly to their judicial tasks."256

In I 965 , Senator Joseph Tydings introduced the Federal Magistrate Act, which, after minor modifications, the Judicial Conference supported in $1967,,^{257}$ and Congress enacted in $1968 .{ }^{258}$ At the time, how-

252 Trial of Minor Offenses, Report of Committee on the Trial of Minor Offenses by Commissioners 4-7 (1943), in Judicial Conference Meetings Records, supra note 50, at Box 34 (Sept. 1944Sept. I945), tbl. 25 (discussing the possibility of extending jurisdiction to commissioners, noting the "constitutional question" whether Congress could confer "on an officer holding tenure other than good behavior, jurisdiction to try any cases arising within the states and outside of Federal reservations"; and given that the question "may eventually be presented for judicial determination," attempting to avoid it by empowering commissioners to impose sentence on petty offenders, most of whom pleaded guilty rather than went to trial); see also Excerpts of Report on Seamen's Wages, supra note 250, reprinted in 98 CONG. REC. 6197 (1952) (arguing that the "real point" of a proposed delegation to Coast Guard officials was that the cases called for "a large amount of clerical" accounting, done by court clerks, and that the facts required for adjudication were often difficult to ascertain).

253 See Memorandum re: Use of Special Master to Supervise Pre-Trial Discovery in Protracted Cases (Jan. $2 \mathrm{I}$, 1957), in Judicial CONFERENCE RECORDS/AO ColleCTION, supra note 50, at Binder Mar. 1957 , supplemental agenda, Item 9.

254 See Handmarked Report by Judge Biggs 27 (Feb. 24, 1958), in JUDICIAL ConFERENCE RECORDS/AO COLLECTION, supra note 50, at Binder Mar. 1958; Exhibit 5 to the Joint Report of the Committee on Supporting Personnel and the Committee on Court Administration in JudICIAL CONFERENCE RECORDS/AO COLLECTION, supra note 50, at Binder Mar. 1958.

255 See Budget Committee Report 5 ( 1960 ), in Judicial ConfERENCE RECoRdS/AO CollecTION, supra note 50, at Binder Sept. I 960 .

256 See Report of the Committee on Court Administration 3, app. at 26 (1964), in JUDICIAL CONFERENCE RECORDS/AO COLLECTION, supra note 50, at Binder 1: Sept. I964.

257 See Report by the chair George C. Edwards, Jr. of the Committee on Administration of Criminal Law 12-15 (Sept. 1966), in Judicial CoNfERENCE RECORDS/AO ColleCTION, supra note 50, at Binder I: Sept. r 966 (reviewing S. 3475 , a bill designed to abolish the Office of U.S. Commissioners and to establish Magistrate Judges, but expressing concerns that delegation to magistrates was "too broad in scope" and specifically suggesting that the power of contempt not be given); see also 1967 JUDICIAL CONFERENCE REPORT 38-40 (supporting the bill as modified).

258 See Pub. L. No. 90-578, Tit. I, § I01, 82 Stat. I 108 (1968). See generally Linda Silberman, 
ever, the conception was that such "judicial officers" were assistants to district judges, appointed by district judges, but were not themselves "judges."259 Illustrative of an understanding that this role was subsidiary, ${ }^{260}$ the vast majority of magistrates appointed in 1970 were part-time. ${ }^{261}$ Over the decades, both the numbers of full-time magistrates and their powers grew. ${ }^{262}$ Despite a few protests by lower court judges about unconstitutional delegations, ${ }^{263}$ the circuits have upheld magistrates' powers over an array of tasks, including, with consent of the parties, trying civil actions. ${ }^{264}$

Beginning in the I 980 , attention turned to whether adding magistrates could suffice in lieu of requesting more life-tenured judgeships and to whether some life-tenured positions could be decommissioned. ${ }^{265}$ By 1990 , when magistrates were renamed "magistrate judges,"266 the idea that these judicial officers were not "judges" had

Masters and Magistrates: The English Model, Part I; Masters and Magistrates, The American Analogue, Part II, 50 N.Y.U. L. REV. 1070, 1297 (1975).

259 Federal Magistrates Act: Hearings on S. 995 Before the Subcomm. on Improvements in Judicial Machinery of the Senate Comm. on the Judiciary, 9oth Cong. 241j-245 (1967) (Statement of Warren Olney and accompanying reports from the Judicial Conference Committee on the Administration of the Criminal Law).

260 See Robert C. Belloni \& Dean Robert R. Yegge, Personnel: Magistrates; Referees in Bankmuptcy, Probation Officers, in Reports of the Conference for District Judges, supra note 8I, at 2 I921 (describing the lack of uniformity in the use of magistrates in the early I970s and the debate among judges about whether magistrates could function as "assistant judge[s]" or whether they should have "defined specialized functions").

261 When magistrate judges were first authorized, the number of part-time magistrates (44I) overshadowed the number of full time positions (6r). See 1969 JUDICIAL CONFERENCE REPORT $30-3 \mathrm{I}$. In the 30 years since, that ratio has flipped. Authorized for fiscal year 2000 are 518 magistrates, of whom 447 are full time. See Conversation with Staff of Magistrate Judges' Division, AO (Nov. 19, ig99).

262 See Federal Magistrate Act of 1979, Pub. L. No. 96-82, \& 3(a)-(d), 93 Stat. 644-45 (codified at 28 U.S.C. $\$ 636(\mathrm{c})(\mathrm{r} 994))$. But see Reinier Kraakman, Article III Constraints and the Expanding Civil Jurisdiction of Federal Magistrates: A Dissenting View, 88 YALE L.J. 1023 (1979) (discussing the constitutional problems raised by the additional delegation).

263 See, e.g., Geras v. Lafayette Display Fixtures, Inc., 742 F.2d 1037, 1045 (7th Cir. 1984) (Posner, J., dissenting); Lehman Bros. Kuhn Loeb Inc. v. Clark Oil \& Refining Corp., 739 F.2d 1313, I 319 (8th Cir. 1984) (Arnold, J., dissenting); Pacemaker Diagnostic Clinic of America, Inc. v. Instromedix, Inc., 725 F.2d 537, 547 (9th Cir. 1984) (en banc) (Schroeder, J., dissenting).

264 See Federal Magistrate Act of 1979 , Pub. L. No. 96-82, $\S 2$ (2), 93 Stat. 643-44 (codified at 28 U.S.C. $\$ 636(\mathrm{c})$ (1994)) (authorizing magistrates to try civil actions upon the consent of all parties). Subsequent amendments encouraged use of this procedure. See Pub. L. No. 104-3 I 7, § 207(I)(B), I Io Stat. 3848 (1996) (providing for appeal of decisions directly to the court of appeals rather than to the district court first); Pub. L. No. 10I-650, $\$ 308(\mathrm{a})(\mathrm{I})-(2)$, 104 Stat. 5112 (1990) (removing the prohibition against trying to persuade parties to consent to such trials).

265 As described in a 1983 annual report, the Subcommittee on Judicial Statistics planned to consider, "in more detail than in past surveys, the use of magistrates in evaluating judgeship needs in the district courts. The Subcommittee also plan[ned] to explore the possibility of recommending decreases as well as increases in the number of authorized judgeships." I983 JUDICIAL CONFERENCE REPORT 61.

266 See Civil Justice Reform Act of 1990, Pub. L. No. 101-650, 32 I, 104 Stat. 5089, 5 II 7. 
disappeared. Indeed, Congress specified that "judicial officers" (and thus both district and magistrate judges) could implement the I 990 reform aimed at reducing civil justice delay and cost. ${ }^{267}$ During the following decade, the number of full-time magistrate judges rose from 307 to $4477^{268}$ by 1999 in ten districts, the number of magistrate judges was greater than the number of life-tenured judges. ${ }^{269}$ Some districts also put magistrate judges "on the wheel," assigned directly to civil cases, as are district judges. ${ }^{270}$

A preference for magistrate judges can be explained by considering the comparative "prices" of a life-tenured judgeship and of a magistrate judgeship. Not only are Article III judges more expensive in dollar terms, ${ }^{271}$ they also create possibilities for party patronage and

267 See 28 U.S.C. $\$ 473(a)(2)$ (1994) (promoting "early and ongoing control of the pretrial process through the involvement of a judicial officer"); 28 U.S.C. $\$ 482$ (I994) (defining "judicial officers" to include both district and magistrate judges). In contrast, the initial proposal had recommended that judges "take a more active role in managing their cases, ending the practice in some courts of delegating to magistrates functions that are in fact better performed by judges." TASK FORCE ON CIVIL JUSTICE REFORM, JUSTICE FOR ALL: REDUCING COSTS AND DELAY IN CIVIL LITIGATION 3 (1989). The current charter of magistrate judges is detailed in 28 U.S.C. $8 \S 631-39$ (I994) and in a report prepared by the Magistrate Judge Division of the $\mathrm{AO}$ of the U.S. Courts that reviewed case law on the constitutionality of delegation of certain aspects of judging and concluded that increased reliance on magistrate judges was appropriate. See A Constitutional Analysis of Magistrate Judge Authority, 150 F.R.D. 247, 302 -05 (1993).

268 See ADMINISTRATIVE OFFICE OF THE U.S. COURTS, ANNUAL REPORT OF THE DIRECTOR 247 (1972); Conversation with staff at the Magistrate Judges' Division of the AO (Nov. I9, 1999). From I97I, when 83 full-time magistrates worked, until 2000, when 447 were authorized, their numbers increased by $439 \%$.

269 Those districts are the Middle and Southern Districts of Alabama, the Western District of New York, the Districts of Nevada, New Mexico, and Arizona, the Eastern and Southern Districts of California, the Middle District of Florida, and the Western District of Texas. See Conversation with staff at the Magistrate Judges' Division of the AO (Nov. 19, 1999).

270 See, e.g., LOCAL RULE FOR THE U.S. DIST. COURT FOR THE DIST. OF OREGON 72. (I999) ("The District of Oregon includes magistrate judges in the random assignment of new civil case filings."). Consent for trials, however, cannot be inferred from a litigant's failure to object to general assignments of cases to magistrates. See Hajek v. Burlington N. R.R. Co., 186 F.3d I Ios (9th Cir. 1999); In re Marriage of Nasca v. Peoplesoft, I60 F.3d 578, 580 (9th Cir. 1998).

Bankruptcy judicial power has followed a similar path to expansion, albeit through lines authorized directly by Congress (but again through selection directly by Article III judges, in this context by appellate judges). See Bankruptcy Act, Pub. L. No. 95-598, 92 Stat. 2549 (1978). Further, the expansion met with some Supreme Court resistance, as Congress chartered bankruptcy court power to come closer to that of Article III judges, thereby blurring the residue of functional distinction that remained and threatening the hierarchical structure. See Northern Pipeline Constr. Co. v. Marathon Pipe Line Co., 458 U.S. 50, 87 (rg82) (plurality opinion). Thereafter, Article III judges opposed life tenure for bankruptcy judges. See Vern Countryman, Scrambling to Define Bankruptcy Jurisdiction: The Chief Justice, the Judicial Conference, and the Legislative Process, 22 HARV. J. ON LEGIS. I (1985). The denouement modified the charter of bankruptcy judges somewhat but retained their non-Article-III status. See Bankruptcy Amendments and Federal Judgeship Act of 1984 , Pub. L. No. 98-353, 8 I04(a), 98 Stat. 336-42 (rg86) (codified at 28 U.S.C. $\$ \S 15$ I -158$)$.

271 The initial cost of a new district judgeship (including salaries, staff, security, and facilities) is $\$ 849,572$; annual recurring costs are calculated at $\$ 758,653$ for fiscal year 2000 . The cost of a full- 
for conflicts between Congress and the Executive. Further, Article III judgeships typically require lag time from judicial request to congressional authorization and executive appointment. In contrast, magistrate judge lines can be created directly by the judiciary, ${ }^{272}$ which remains dependent on Congress for funding but not for appointing or allocating positions.

To make the magistrate judge system work, however, required more from the judiciary than agreeing internally to request such positions and persuading Congress to fund them. Constitutional law had to change to admit either that "essential attributes of the judicial power"273 did not entail many activities once thought to be exclusively the domain of life-tenured judges or that such attributes could constitutionally vest in non-life-tenured judges. ${ }^{274}$ The current doctrine leaves open an unspecified set of limitations emanating from Article III that could serve as a basis for refusing some forms of congressional expansion while at the same time sanctioning an array of alternative institutional adjudicatory arrangements of significant and useful proportions. 275

Thus, the Article III judiciary joined in the manufacture of judgeships, albeit most of them without life tenure. Depending on one's vantage point, the judiciary either has failed to seek all the life-tenured judges required for federal adjudication and has given Congress incentives not to create more life-tenured judgeships, or it has succeeded in

time magistrate judgeship averages $\$ 684,834$ in startup costs and $\$ 596,75$ I each year thereafter. See Unit Cost Tables for New and Existing Judgeships and Positions, FY 2000, First Year and Annual Recurring Cost for Judgeships, Fiscal Year 2000 (chart, provided by staff at the AO) (on file with the Harvard Law School Library). Magistrates (and bankruptcy judges) are paid $\$ 129,996$; district judges receive \$141,300. See Salary Rates supra note 179 , at 3.

272 See 28 U.S.C. \$ 631 (a) (1994) ("The judges of each United States district court ... shall appoint United States magistrates in such numbers and to serve in such locations within the judicial district as the conference may determine under this chapter.").

273 Crowell v. Benson, 285 U.S. 22, 51 (r932).

274 The plurality opinion in Northern Pipeline signaled some concerns about the scope of power delegable - there to bankruptcy judges, but the balancing test subsequently endorsed by the majority in Commodity Futures Trading Commission v. Schor, 478 U.S. 833, 847-59 (1986), offered a broader view of permissible delegation. The Court held that administrative judges were authorized to consider related state claims when ruling on statutorily created rights under the Commodity Futures Trading Act.

While I share with Justice White a certain affection for a "simple reading" of Article III that would have permitted only life-tenured judges to be "federal judges," Northern Pipeline, 458 U.S. at 93 (White, J., dissenting), the long history of departures from that model that he noted (including judges of territorial courts) make unlikely a constitutional interpretation limiting the use of the title "federal judge" exclusively to Article III judgeships.

275 See generally Richard H. Fallon, Jr., Of Legislative Courts, Administrative Agencies, and Article III, IOI HARV. L. REV. 915 (1988); Judith Resnik, The Mythic Meaning of Article III Courts, 56 U. CoLO. L. REV. 58 I (1983). 
obtaining significant increases in the numbers of life-tenured judges ${ }^{276}$ and has helped to generate non-life-tenured judges to fill some of the gap.

3. Blurring Roles. - A brief summary is in order. Over this century, the Article III judiciary as an entity has developed the views that (a) it is too busy from too high a volume of cases; (b) it is important and should be reserved for special assignments; (c) it should not expand its own numbers too much in response to the demands for more judging; (d) adjudication by non-life-tenured judges should be a presumptive substitute for adjudication by life-tenured judges; and (e) less judging and more settling is appropriate in general.

These positions take official form through the publication of the federal judiciary's 1995 Long Range Plan. But the Long Range Plan does more than object to increased jurisdiction without provision of additional resources, ${ }^{277}$ and the Plan does more than petition for reallocation of work to non-life-tenured judges. ${ }^{278}$ The opening recommendations of this first "mission" statement call for limitations on federal court jurisdiction in general. The Third Branch has asked Congress to create a presumption against enacting any new federal civil causes of action if enforced in federal court, ${ }^{279}$ as well as a pre-

276 Measured against a baseline of the number of life-tenured judgeships extant when the Conference began, significant increases in their numbers have occurred throughout the century. For example, in 1958, 404 judgeships were authorized; in 1966, 487 judgeships; in 1978, 678 judgeships; in 1989, I035 judgeships; and in 1996, 244 judgeships. See ADMINISTRATIVE OFFICE OF THE U.S. COURTS, ANNUAL REPORTS OF THE DIRECTOR: I958 REPORT 143; I966 REPORT 74; I978 REPORT 128; I989 REPORT 45 tbl.20; and I996 REPORT 40 tbl.12. The growth in numbers of non-life-tenured judges is discussed above at pp. 989-9I.

277 See LONG RANGE PLAN, supra note 111, at 75 (arguing that "uncontrolled growth" is "unfortunate" either because it would beget "( $\mathrm{I})$ an enormous, unwieldy federal court system that has lost its special nature; or (2) a larger system incapable, because of budgetary constraints, workload and shortages of resources, of dispensing justice swiftly, inexpensively and fairly").

278 See id. at 93 (Recommendation 9) (calling on Congress to reallocate Social Security disability claims to administrative adjudication); id. at 94 (Recommendation Io) ("Where constitutionally permissible, Congress should be encouraged to assign to administrative agencies or Article I courts the initial responsibility for adjudicating those categories of federal benefit or regulatory cases that typically involve intensive fact-finding." 7 . The LONG RANGE PLAN echoes some proposals of the I990 FCSC REPORT. See supra note III, at 55 ("Some current aspects of federal court business could be handled more effectively and expeditiously through new or reorganized judicial or administrative procedures outside the third branch, subject to appropriate Article III review.").

279 See Long Range Plan, supra note i I $\mathrm{I}$, at 83 (Recommendation $\mathrm{I}$ ) (urging Congress to confer jurisdiction on the federal courts only upon a finding of "clearly defined and justified national interests"); id. at 88 (Recommendation 6) ("Congress should be encouraged to exercise restraint in the enactment of new statutes that assign civil jurisdiction to the federal courts and should do so only to further clearly defined and justified federal interests."). The LONG RANGE PLAN describes areas of "federal interest" justifying jurisdictional grants to the federal courts to be cases that arise under the Constitution; cases that "deserve" federal adjudication because of unsatisfactory state responses and either a "strong need for uniformity" or a "paramount [federal] interest"; cases that involve foreign relations; cases in which the federal government or its officials 
sumption against prosecuting more crimes in federal courts. ${ }^{280}$

Two aspects of the judicial posture thus come into focus. First, while conceptually distinct, in recent decades the federal judiciary's institutional and adjudicatory modes have blurred. Ideas of the judiciary as an administrative agenda-setter are not insulated from its work as a constitutional adjudicator; rather, they are intertwined. For example, with increasing insistence beginning in the $1980 \mathrm{os}$, members of the judiciary began to campaign against "federalization of crime." These views obtained corporate status in 1995 in the Long Range

are parties; and cases that arise from "disputes between or among the states" or that "affect substantial interstate or international disputes." Id. at 88-89. The commentary also posits a "high" burden for Congress to satisfy before granting jurisdiction and gives "patent, trademark, and copyright laws" as examples meeting that test. Id. at 82-88.

Although the LONG RANGe PLAN mentions the federal courts' role in the "preservation of individual rights and liberties found in the Bill of Rights and subsequent amendments ... [and in] protection - through the writ of habeas corpus - of persons held in violation of the Constitution or federal law," id. at 88, the discussion is unclear about what role federal courts should play in enforcing statutory civil rights based either on legislation following the Civil War or on more recent enactments. Noting that "the federal courts have played a vital role in promoting civil rights and in eliminating invidious discrimination," $i d$. at 88 , the LONG RANGE PLAN also urges Congress to:

recognize that all state judges take an oath to uphold the U.S. Constitution and the supremacy of federal law. Absent a showing that state courts cannot satisfactorily deal with an issue, Congress should be hesitant to enact new legislation enforceable in the federal courts, and should not do so in any event without a concomitant reduction of federal jurisdiction in other areas.

Id. at 88-89. Thus, although the LONG RANGE PLAN gives an unqualified endorsement of patent and copyright litigation in federal courts, the Plan is less certain about the place that civil rights actions should hold.

The Long Range Plan's approach accords with that expressed by Chief Justice Rehnquist in several of his annual addresses. See, e.g., Rehnquist, I99I Year-End Report, supra note 238, at 4 ("New additions [to federal jurisdiction] should not be made unless critical to meeting important national interests which cannot otherwise be satisfactorily addressed through non-judicial forums, alternative dispute resolution techniques, or the state courts.").

280 See LoNG RANGE PLAN, supra note 111 , at 84-85. "Recommendation 2 " lists five types of offenses properly in federal courts, including ( $\mathrm{I}$ ) an "offense against the federal government" or its agents or against "interests unquestionably associated with a national government, or [an area over which] the Congress has evinced a clear preference for uniform federal control"; (2) offenses involving "substantial multistate or international aspects"; (3) offenses within a single state involving a "complex commercial or institutional enterprise most effectively prosecuted by use of federal resources or expertise"; (4) proscribed activities involving local corruption; and (5) proscribed activities raising "highly sensitive issues" for a local community that make the crimes "more objectively prosecuted within the federal system." Id.

Again, commentary by Justices in other settings offers similar views. See, e.g., Dep'ts of Commerce, Justice, and State, the Judiciary, and Related Agencies Appropriations for 1996: Hearings Before a Subcomm. of the House Comm. on Appropriations, 104th Cong. 13 (1995) (statement of Justice Kennedy) (discussing his concerns "with any increase across the board in Federal crimes, particularly for matters that have historically been left to the States ${ }^{\prime}$; id. at 17 (statement of Justice Souter) ("I think it safe to say, not a person is going to want to become a Federal judge, if what he has to face 60 or 70 percent of his time is handling routine criminal cases that in my day as a State court judge we handled."). See generally Symposium, Federalization of Crime, 46 HASTINGS L.J. 965 (1995). 
Plan. ${ }^{281}$ In the same year, the Supreme Court imposed such a limit in one arena as a matter of constitutional law - in United States $v$. Lo$p e z,{ }^{282}$ which held that Congress lacked the power to confer federal jurisdiction over crimes of gun possession within rooo yards of a school. ${ }^{283}$ Similarly, although federal judges have not (as policy makers) been able to persuade Congress to refrain from creating or to repeal certain civil causes of action, they have (as judges) found unconstitutional some of the applications of rights that Congress has articulated. ${ }^{284}$ Moreover, even when pending litigation about such statutes raises constitutional questions, some federal judges comment on those statutes and the desirability of retrenchment. ${ }^{285}$

281 See LONg RANGe PLAN, supra note $\mathrm{III}$, at 82 (criticizing Congress for its decisions "to 'federalize' crimes previously prosecuted in the state courts and to create civil causes of action over matters previously resolved in the state courts"); id. at 84-85. As noted, the ABA has also endorsed these concerns. See supra note 222.

282514 U.S. 549 (1995).

283 See id. at 567.

284 See, e.g., Alden v. Maine, 119 S. Ct. 2240, 2269 (1999); Seminole Tribe v. Florida, 5 I 7 U.S. 44, 76 (1996); see also City of Boerne v. Flores, 521 U.S. 507, 536 (1997) (holding that in enacting the Religious Freedom Restoration Act, Congress had exceeded its powers under Section 5 of the Fourteenth Amendment); Brzonkala v. Virginia Polytechnic Inst. and State Univ., I69 F.3d 820, 889 (4th Cir. I999) (en banc), cert. granted sub nom. United States v. Morrison, I20 S. Ct. II (I999) (holding that Congress lacked power to create civil rights remedy for gender-based animus); Brown v. North Carolina Div. of Motor Vehicles, I66 F.3d 698 (4th Cir. 1999), petition for cert. filed, 68 U.S.L.W. 3164 (U.S. Sept. 8, I999) (No. 99-424) (holding that Congress lacked the authority to abrogate state immunity in the Americans with Disability Act and dismissing a lawsuit against North Carolina brought under that statute).

Another way to impose constraints on filings is to limit the remedies available under congressional grants of jurisdiction. See, e.g., Ferguson v. City of Phoenix, 157 F.3d 668, 676 (9th Cir. 1998), cert. denied, 514 U.S. 1004 (1999) (holding, in a challenge that the absence of provisions for individuals who were hearing-impaired in a city's emergency 911 system violated the Americans with Disability Act, that compensatory damages were not available without a showing of discriminatory intent, and that a Department of Justice notice of deficiencies followed by inaction did not suffice to establish such intent).

285 For example, Chief Justice Rehnquist praised restrictions on habeas corpus jurisdiction and on prisoners' civil rights actions, both termed 'promising examples of how Congress can reduce the disparity between resources and workload in the federal Judiciary without endangering its distinctive character." Rehnquist, 1997 Year-End Report, supra note 238, at 2. The Chief Justice then complained that such legislation was insufficiently frequent ("sporadic and inconsistent") and added: "I therefore call on Congress" to do more to "reduce the jurisdiction of federal courts." Id.

The constitutionality of the restrictions on habeas jurisdiction has been before the Court in a few cases, including Felker v. Turpin, 518 U.S. 651 (I996), and Hohn v. United Slates, 524 U.S. 236 (1998). Jurisdictional limitations on the Illegal Immigration Reform and Immigrant Responsibility Act of 1996 were considered in Reno v. American-Arab Anti-Discrimination Committee, I 9 S. Ct. 936 (1999). The legality of the Prison Litigation Reform Act of 1996 (PLRA) has been debated at the circuit court level. See, e.g., Benjamin v. Jacobson, 172 F.3d I44 (2d Cir. I999) (en banc) (reversing panel interpretation requiring state court enforcement of consent decrees and upholding the PLRA's restrictions); Taylor v. United States, I43 F.3d I178 (9th Cir. 1998), affd as modified on reh'g, I8I F.3d I0I7 (9th Cir. 1999) (en banc). Whether aspects of the PLRA violate separation of powers doctrine will be considered by the Supreme Court this Term; the Seventh Circuit held that a provision of the Act, involving automatic stays, unconstitutionally encroached 
Second, the judiciary's posture towards its institutional role in shaping its own jurisdiction has shifted. Individual members of the federal judiciary have long complained, in opinions and essays, and through committee reports, about being required to adjudicate particular kinds of cases, such as those arising under diversity jurisdiction or under specific statutory grants, or filed by prisoners. ${ }^{286}$ Further, as discussed above, since the middle of the twentieth century, the Judicial Conference has objected to specific proposed jurisdictional grants and has endorsed limitations on extant provisions. What is different and new - is the emergence of a broad objection at the institutional level. The federal judiciary now counsels Congress against creation of new federal rights in general, if these rights are to be enforced in federal courts. This theme has been powerfully articulated by the Chief Judge of the Fourth Circuit in his testimony to Congress: "Uncontrolled growth in judges and jurisdiction is the single greatest problem the federal judiciary has to confront."287

For those enamored with "The Federal Courts" because they assume that inherent in the charter of life-tenured judges is a commitment to guarding rights, it may well be time to leave behind that romance. ${ }^{288}$ As an educational and rulemaking organization, the federal judiciary has adopted an anti-adjudication and pro-settlement agenda. As a lobbying organization, the federal judiciary has chosen to oppose creation of new federal rights, to support retrenchment of the roles of life-tenured judges, and to propose delegation of many of their tasks to other judges.

on the federal courts. See French v. Duckworth, 178 F.3d 437, 444 (7th Cir. 1999), cert. granted sub nom. Duckworth v. French and United States v. Duckworth, 120 S. Ct. 578 (U.S. Dec. 6, r 999) (Nos. 99-224, 99-582).

286 See, e.g., Lewis F. Powell, Jr., Are the Federal Courts Becoming Bureaucracies?, 68 A.B.A. J. 1370,1371 (1982) (singling out prisoner filings and civil rights "tort" litigation); John W. Winkle III, Judges as Lobbyists: Habeas Corpus Reform in the I940s, 68 JUDICATURE 263 (1985). Further, some Chief Justices have been energetic lobbyists. Taft was very active; as Fish put it: "No question of propriety gnawed at Taft's conscience." FiSH, supra note 20, at 79. A more recent example is Warren Burger, who worked to prevent bankruptcy judges from becoming Article III judges. See Countryman, supra note 270 , at IO-I I.

287 Statement of Judge Wilkinson, supra note 242, at I5. In his concurrence in Brzonkala, 169 F.3d at $895-96$, Judge Wilkinson described different forms of what he termed judicial activism and argued that such activism in invalidating congressional creation of new civil rights was appropriate to protect the structure of the government he envisioned.

288 If still holding on to it. See generally ROBERT M. COVER, JUSTICE ACCUSED: ANTISLAVERY AND THE JUDICIAL PROCESS (1975) (discussing federal court enforcement of fugitive slave laws); Purcell, Histories of Lower Federal Courts, supra note I86, at 690-94 (discussing the conservative role played by the federal courts in the early twentieth century); Judith Resnik, The Federal Courts and Congress: Additional Sources, Altermative Texts, and Altered Aspirations, 86 GEO. L.J. 2589 (1998). 


\section{READING A CENTURY'S Changes}

Piecing together a century-long narrative invites interpretative evaluation. ${ }^{289}$ What is to be made of these transformations? The record inspires both appreciation and distress, drawn from thinking about the constitutional and cultural roles that the institution of judging occupies.

\section{A. Generativity}

Consider first the degree to which a collective of judges, lawyers, and academics reoriented the institutions of which they were a part. ${ }^{290}$ They wrote new rules, invented organizations, and changed both the ways that judges and lawyers behaved and the courts in which they worked. ${ }^{291}$ They promoted a vision of a public good that, while put-

289 Also invited is self-consciousness about the inevitably situated stories told. This essay does not, for example, explore the effects of changes in the legal profession, the rise of private providers of judicial services, the role of business and the economy, and structural changes in the other branches of the federal government as well as in state systems.

Further, several counterexamples could be elaborated to demonstrate ambivalence and compromise within the judiciary in its corporate and adjudicative roles. For example, expansionistic efforts by the federal courts to increase their jurisdictional reach can be found, both in the early years of this century's Eleventh Amendment jurisprudence and in more recent interpretations, in the area of preemption. For example, see Ex parte Young, 209 U.S. 123, I42 (1908) and some of the cases involving preemption under ERISA in which the federal courts' approach has imposed federal requirements, arguably beyond statutory mandates, on aspects of state pension, health benefits, and trust law. See John H. LANG Bein \& BRUCE A. WOLK, Pension AND EMPLOYEE BENEFIT LAW 416-506 (2d ed. I995); see also Fallon, Ideologies, supra note 219, at II45 (discussing competing narratives of federal jurisprudence, one expansionistic and the other committed to state governance).

Yet another caveat stems from keen awareness that "the judicial process" is ever-changing, and that forms of proceedings appearing quintessentially "judicial" in one century or country diminish in import from the vantage point of a century or an ocean away. See generally MIRJAN $R$. DAMASKa, EVIDENCE LAW ADRIFT (I997); MiRJAN R. DAMASKa, The Faces OF JUSTICE AND STATE AUTHORITY: A COMPARATIVe APPROACH TO THE LEGAL ProcesS (1986); John H. Langbein, Historical Foundations of the Law of Evidence: A View from the Ryder Sources, 96 COLUM. L. REV. I 68 (I996); John H. Langbein, Shaping the Eighteenth-Century Criminal Trial: A View from the Ryder Sources, 50 U. CHI. L. REV. I (1983). A small example is provided in Judith Resnik, Judging Consent, I987 U. CHI. LEGAL F. 43, in which I discuss the history of the use of consent decrees and their original utility as a means of verification of transactions.

290 See ANThony T. KRonman, The Lost LaWYer: Failing Ideals of the Legal ProFESSION 3 (1993) (describing images of lawyers as "statesmen" fashioning institutions).

291 Many were self-conscious and self-celebratory when doing so. See, e.g., Charles E. Clark, The Role of the Supreme Court in Federal Rule-Making, 46 J. AM. JUDICATURE SOC'Y 250, 254 (Ig63) (describing the drafting of the federal rules as a "lawyers' job . . . accomplished with lawyers' skill," and proclaiming that those rules represented "one of the major turning points of English and American legal history," in that they permeated "the daily professional life of all lawyers" and reshaped "law school curricula and teaching"). 
ting lawyers at its center, did not invariably reflect the interests of the class or clients with whom they were associated. ${ }^{292}$

Further, I have focused on but two of many agendas that engaged the federal judiciary, which - upon gaining an organizational structure - has also focused on the difficulties of the litigants within it and the staff working for it. For example, between the r940s and r96os, the judiciary took up projects such as the creation of alternatives to incarceration for youthful offenders and the provision of legal services for criminal defendants. ${ }^{293}$ The judiciary also worked on the problems of its clerical staff, court reporting, and probation. ${ }^{294}$ And while attempting to increase their own remuneration, life-tenured judges also continue to work hard for pay less than that of many of their counterparts.

The achievement of particular interest here has been the fashioning of the federal judiciary into a branch of government. Only in the twentieth century did the judiciary (with the approval and funding of Congress) obtain a means of self-directed policymaking, an administrative arm for implementation, and an educational apparatus for perpetuation. These developments could be seen as bringing into focus the constitutional image of the judiciary, now a player in conversations with its federal co-branches and with its counterparts in the states. ${ }^{295}$

292 For example, the reforms enabled greater access to courts and invented discovery (aptly termed a "poor person's FBI" by my colleague Owen Fiss). See Judith Resnik, Failing Faith: Adjudicatory Procedure in Decline, 53 U. CHI. L. REV. 494, 498-505 (I986) (hereinafter Resnik, Failing Faith] (discussing the professional background of the ruledrafters). On the other hand, the I930s rules (and particularly their discovery provisions) have also provided employment opportunities for many lawyers. The complexity of the relationship between the innovations of the I938 rules and lawyers' fees is explored in George B. Shepherd \& Morgan Cloud, Time and Money: Discovery Leads to Hourly Billing, I999 U. ILL. L. REV. 91.

293 One example is the Federal Youth Corrections Act (FYCA), i 8 U.S.C. \$§ 5005-5026 (1950), repealed by Comprehensive Crime Control Act of 1984, Pub. L. No. 98-473, 218,98 Stat. 2027 (codified as amended in scattered sections of 18 U.S.C.); see also Fred C. Zacharias, The Uses and Abuses of Convictions Set Aside Under the Federal Youth Corrections Act, I98 I DUKE L.J. 477. Another example can be found in efforts to create a federal public defender. See Bills to Provide for the Representation of Indigent Defendants in Federal Criminal Cases: Hearing on H.R. 398 \& H.R. 2091 Before Subcomm. No. 4 of the House Comm. on the Judiciary; 83rd Cong. 3 1-37 (1957) [hereinafter Public Defender Hearings] (statement of John J. Parker, Chief Judge, U.S. Ct. App.,

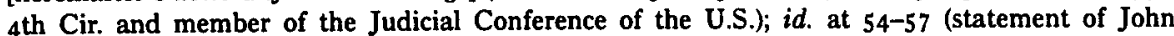
Biggs, Jr., Chief Judge, U.S. Ct. App., 3d Cir. and member of the Judicial Conference). The end result was the enactment of the Criminal Justice Act, Pub. L. No. 88-455, 78 Stat. 552 (1964) (codified at 18 U.S.C. 83006 A (1994)).

294 See also 1940 JUDICIAL CONFERENCE REPORT, reprinted in ANNUAL REPORT OF THE ATTORNEY GENERAL OF THE UNITED STATES FOR THE FISCAL YEAR 1940, at 2 I (noting that the "general supervision" of probation was a task of the $A O$ and that parole officers worked under the aegis of the bureau of prisons within the Department of Justice).

295 An indication that the federal judiciary has come into its own is its participation in a series of "first ever" meetings, including an all-branch conference convened in the Iggos and a statefederal conference held in I992. See Malcolm M. Lucas, Keynote Address: National Conference on State-Federal Judicial Relationships, 78 VA. L. REV. 1663 (1992). In the 1990s, in order to en- 
Given parallel transformations of other institutions of governance over the century, the federal judiciary might thus be credited with equipping itself to function within the contemporary administrative state. ${ }^{296}$

More than that: the federal judiciary should be applauded for expanding the adjudicatory resources of the administrative state to respond to citizen demand. As expositors of the meaning of the Constitution, the life-tenured judiciary has read Article III to permit Congress to send many kinds of federal cases to non-life-tenured judges. ${ }^{297}$ That interpretation permits the staffing of hundreds of courts within agencies that provide first-tier decisionmaking for disputants. Assuming that the judiciary understood correctly that the political wherewithal never existed to produce 4000 plus life-tenured judges, the minimum number ${ }^{298}$ that would have been necessary to respond to demand, the life-tenured judiciary adapted through invention. Its routes to expansion of judge-power now include the ability to create magistrate judgeships and the authority to seek both bankruptcy and life-tenured judgeship lines from Congress. Moreover, for magistrate judgeships, the task has been simplified; only funding rather than statutory approval of new judgeship lines and senatorial approval of individual judges - is required.

The judiciary's record of enabling the use of auxiliary judges is part of a more general picture of federal judicial competence as a participant in governance. As a policymaker, the federal judiciary has forged a series of agreements with Congress, ${ }^{299}$ not only about magistrate and bankruptcy judges but also to provide forms of material richness greater than many state courts. Federal courts are "richer"

courage joint undertakings and describe joint seminar, meetings, and undertakings, the FJC began to publish the STATE-FEDERAL JUDICIAL OBSERVER: NEWS AND COMMENTARY OF INTEREST TO THE STATE AND FEDERAL JUDICIARY; the last issue was published in 1998 . For specific case-related activities, see William W Schwarzer, Nancy E. Weiss \& Alan Hirsch, Judicial Federalism in Action: Coordination of Litigation in State and Federal Courts, 78 VA. L. REV. 1689 (I992).

296 Efforts to disentangle court management from the executive or legislative branch and to develop governance mechanisms have also occurred in many states. See, e.g., James H. Brickley, Justice in Michigan: A Program for Reforming the Judicial Branch of Government: A Report to the People of Michigan from the Justices of the Michigan Supreme Court, 74 MICH. B.J. II3I (Nov. 1995) [hereinafter Brickley, Michigan Judicial Reform]; Dianne Molvig, Is Our Judiciary a Co-Equal Branch of Government?, WIS. LAW., Aug. 1997, at 14.

297 Beginning with Crowell $ข$. Benson, 285 U.S. 22 (1932), the judiciary authorized limited delegation but required a return of "jurisdictional facts." This mandate has broadened. See, e.g., Commodities Futures Trading Comm'n v. Schor, 478 U.S. 833 (1986); Thomas v. Union Carbide, 473 U.S. 568 (1985); supra note 274.

298 This number is based on the number of non-life-tenured judges currently in courts and agencies. See supra notes 94 , 101-102.

299 See Vicki C. Jackson, Congressional Control of Jurisdiction and the Future of the Federal Courts - Opposition, Agreement, and Hierarchy, 86 GEO. L.J. 2445, 2451-52 (1998) (describing consensus as one of the narratives of the relationship between Congress and the federal courts). 
than many state courts, as measured by an interplay of factors including the pay scales of life-tenured judges, the ratio of judges to cases, the quantity of courtroom space, and staffing. ${ }^{300}$ The status of a federal judgeship - despite century-long commentary about its precariousness - remains prized.

\section{B. Diffused Judging}

Consider next the content of the job of judging. Here, the record is more mixed. Some theories of litigation posit lawsuits as a useful means of enforcing the law, that the filing of cases (whether by private parties or by public regulators) and the resultant judicial decisionmaking are beneficial means of furthering state regulation. ${ }^{301}$ Through the informality of settlement processes, however, powerful disputants are able to take many complaints away from public view, limit access to information, and make private deals. ${ }^{302}$ Third parties, potentially similarly situated, lose one source of information about the behavior of repeat-player participants. Settlement and alternative dispute resolution (ADR) are thus forms of privatization and deregulation interacting with other efforts to dismantle the national regulatory apparatus put into place through the New Deal. ${ }^{303}$

Contemporary promotion by the federal judiciary of judicial control, management, and settlement as central aspects of federal trial judges' jobs facilitate such privatization. ${ }^{304}$ Celebration of these poli-

300 Some comparative data are provided in Judith Resnik, History, Jurisdiction, and the Federal Courts: Changing Contexts, Selective Memories, and Limited Imagination, 98 W. VA. L. REV. I7I, 252 n.303 (1995) [hereinafter Resnik, History, Jurisdiction, and the Federal Courts]. The budgetary successes of 1999 are recounted in Finally a Budget!, THIRD BRANCH, Dec. I999, at I2.

301 See Owen M. Fiss, Against Settlement, 93 YALE L.J. 1073, 1085-87 (1984).

302 The degree to which such agreements are made public is an artifact of law. If cases end by dismissal predicated upon parties' agreement, all that may be public are notices or stipulations of dismissal. See Leucadia Inc. v. Applied Extrusion Techs., Inc., 998 F.2d 157, 165 (3d Cir. 1993) (discussing the requirements of FED. R. CIV. P. 4I). When parties end litigation with consent decrees, however, such decrees are presumptively accessible to the public. See Bank of America Nat'l Trust and Sav. Ass'n v. Hotel Rittenhouse Assocs., 800 F.2d 339, 346 (3d Cir. 1986) (holding that an interest in encouraging settlements does not outweigh the public's right of access to consent decrees filed with the court). Moreover, some states have imposed requirements of databasing and disseminating information about settlements in certain kinds of cases. See, e.g., FLA. STAT. ANN. \& 627.912 (West 1999) (requiring insurance companies, self-insured funds, and joint underwriting associations that provide professional liability insurance to medical practitioners to report to the Department of Insurance the amounts of payment for either judgments or settlements). Such "closed claim reports" are public record. See Closed Claim File Ordering (visited Jan. 5, 2000) <http://www.doi.state.fl.us/liability/plccorde.htm>.

303 For consideration of the relationship between the 1938 Federal Rules of Civil Procedure and New Deal ideology, see Laurens Walker, The End of the New Deal and the Federal Rules of Civil Procedure, 82 IOWA L. REV. 1269 (1997).

$304 \mathrm{My}$ focus here is on the trial courts. Interest in settlement has also developed on the appellate level, as is exemplified by the creation of civil appeals management programs in which liti- 
cies comes from those committed to a relaxation of regulatory control, as well as from many critics of adversarial processes who view litigation as inadequate responses to disputes. ${ }^{305}$ The federal judiciary's teaching programs and rule adjustments could be understood as creatively pioneering procedures such as individual calendars and management, as helping parties to focus on their interests and goals, as curbing inept or unduly aggressive lawyering, and as responding to workload problems by readjusting processes.

In contrast, objections to the federal judiciary's growing commitment to party accord and informal processes arise from different concerns, varying with one's normative alignments. Worried are a range of critics, including welfare economists disagreeing about the quality of the bargaining between parties of unequal resources, moral theorists criticizing the reliance on consent in lieu of justice and fairness, and critical theorists engaged with problems of the preferences posited as existing ex ante and acontextually. Moreover, deregulation damps down public dialogue about the obligations and rights of citizenship and the functions of a democratic state. Such dialogue - in which norms are developed - depends on a shared space that the polity supports and in which the polity debates its values. ${ }^{306}$ Courts are one such venue, specially suited to the task by their reliance on submissions by contesting parties and their practice of writing and publishing explanations of decisions and disagreements. Private justice makes the

gants are brought together under the aegis of the court to discuss settlement. See FED. R. APP. P. 33 (providing for such conferences); Irving R. Kaufman, Must Every Appeal Run the Gamut? The Civil Appeals Management Plan, 95 YALE L.J. 755 (1986).

In contrast to the trial judiciary's "hands-on" approach, appellate courts offer litigants the services of staff attorneys; appellate judges do not themselves enter into discussions with parties to settle cases pending in the appellate courts. Appellate judges do, upon occasion, serve to assist settlement efforts at the trial level. See, e.g., Ahearn v. Fibreboard, I62 F.R.D. 505, 515-I6 (E.D. Tex. 1995), aff'd sub nom. In re Asbestos Litig., 90 F.3d 963, 970 (5th Cir. 1996) (describing the appointment of Judge Patrick Higginbotham of the Fifth Circuit as a "Settlement Facilitator" in a large asbestos class action involving insurance coverage disputes), judgment vacated and remanded on other grounds, Ortiz v. Fibreboard Corp., 521 U.S. 1114 (1997); John R. Wilke, Microsoft Judge Names Mediator to Seek Award, WALL ST. J., Nov. 22, 1999, at A3 (reporting the appointment of Richard Posner, Chief Judge of the Seventh Circuit, to serve as a mediator).

305 For discussion of the utility of alternative dispute resolution, see Clark Freshman, Privatizing Same-Sex "Marriage" Through Alternative Dispute Resolution: Community-Enhancing Versus Community-Enabling Mediation, 44 UCLA L. REV. 1687 (1997); Carrie Menkel-Meadow, Introduction: What Will We Do When Adjudication Ends? A Brief Intellectual History of ADR, 44 UCLA L. REV. 1613, 1617-18 (1997); Frank E.A. Sander \& Stephen B. Goldberg, Fitting the Forum to the Fuss: $A$ User-Friendly Guide to Selecting ADA Procedure, Io NEgotiation J. 49 (1994); Carrie Menkel-Meadow, For and Against Settlement: Uses and Abuses of the Mandatory Settlement Conference, 33 UCLA L. REV. 485 (1985); and Frank E.A. Sander, Varieties of Dispute Processing, 70 F.R.D. 79 (1976).

306 See, e.g., Michael J. SANDEL, Democracy's Discontent: AMERICA IN SEARCh of a PUBLIC PHILOSOPHY 20I-I I (I996); Frank I. Michelman, The Supreme Court and Litigation Access Fees: The Right to Protect One's Rights - Part I, 1973 DUKE L.J. I 153, I 1 72-77. 
forging of common ground more difficult, yet it is the employees of the public sector - the federal judiciary - who are encouraging this retreat. Ambivalence and contemporary conflict about such a retreat are reflected in disagreements in caselaw debates about the enforceability of contractual accords to withdraw claims from adjudication. ${ }^{307}$

Another objection moves from claims about the role of adjudication in political democracies to arguments about the efficiency of a managerial settlement agenda. The critique is that the stated goals (inexpensive and quick decisionmaking) are not produced by the procedures deployed (case management and judge-run settlement conferences). The empirical bases for such a view come from efforts to measure the effects of judicial case management, such as data from RAND's Institute for Civil Justice, which reviewed case costs and outcomes during the I9gos. RAND concluded that many judicial managerial efforts are resource-consumptive. ${ }^{308}$ For example, because attorneys bill clients when preparing for and attending judicial conferences, increasing the number of such conferences adds cost to some cases. Further, because attorneys might well believe that such conferences could work to their advantage, attorneys may delay bilateral settlement negotiations until after meeting with judges. While attorney investment of such time may, in some cases, benefit clients, and while some negotiations superintended by judges may yield "better" (on some scale) results, some of the investment will be wasted. Hence, while enjoyed by some lawyers and judges, these procedures, designed

307 See, e.g., Wright v. Universal Maritime Serv. Corp., I I9 S. Ct. 39I, 396-97 (1998) (concluding that a union could not waive individual members' statutory rights of access to court by entering into general agreements to arbitrate disagreements with an employer); Neary v. Regents of Univ. of Cal., 834 P.2d II9, 125-26 (Cal. 1992) (creating a presumption that parties can, as part of their agreements to settle cases, require appellate courts to vacate lower court judgments without finding errors of fact or law). The development of such doctrine raises a question about whether New Deal ideology has permanently displaced common law assumptions. Cf. BRUCE A. ACKERMAN, RECONSTRUCTING AMERICAN LAW 9-1 2 (1984) (discussing how New Deal activists became skeptical of common law legal meaning).

Explanations for a focus on consent may come from the political milieu of judges. That contract questions come to the fore in the federal judiciary should not be surprising, given that parallel discussions of "the contract with America" and reliance on self-help (workfare) instead of state assistance (welfare) are ongoing in legislative and executive branches. The substantive goals of deregulation, diminished protection of vulnerable litigants, and delegation of federal statutory rights to other venues reflect the agendas of a series of administrations, able through judicial selection processes to shape the federal bench. See SHELdON GoldMaN, PICKING FEDERAL JUDGES: LOWER COURT SELECTION FROM ROOSEVELT THROUGH REAGAN 359-65 (1997).

308 See RAND JUDICIAL CASE MANAGEMENT EVAlUATION, supra note 1, at 55, 173. RAND's Institute for Civil Justice found that "[e]arly judicial case management is associated with both significantly reduced time to disposition and significantly increased lawyer work hours," and that if trial schedules were set and discovery limited, the median time to disposition could be decreased by several months. Id. at 55 . 
to save, instead take time and cost money. ${ }^{309}$ This critique is unpopular with some of the proponents and users of judicial management, and unsurprisingly, the data are disputed. ${ }^{310}$

Yet another objection, resting on an intersection of constitutional law, sociology, and political theory, focuses on the idea of the judge within the structure of government in the United States. At issue is the shift in the role of a judge from adjudicator to manager to settler to dealmaker. That such role-blurring has occurred is evident from contemporary case law equating judging with settling cases. For example, in a recent appellate decision, the question was whether mediators, like judges, deserve special protection (immunity) from lawsuits filed by disputants unhappy with outcomes. ${ }^{311}$ The federal appellate court ruled that a court-appointed mediator enjoyed judicial immunity from such suits; after reviewing the many tasks of a judge during the pre-trial process, the court found "nothing" in the mediator's role different from that which a judge might have done. ${ }^{312}$

But if a mediator does what a judge does, which one deserves life tenure? Both, or neither? The judicial embrace of roles held by other social actors - the homogenization of the various kinds of dispute resolvers - has made more difficult the task of explaining why some judges should be specially protected, insulated, and respected. The claim (formalistic in part) is that the constitutional grant of authority to federal judges, protected through life tenure and rights to undiminished salary, depends implicitly on those judges acting in a certain manner ("judge-like") - openly and visibly taking the risk of rendering public judgments on disputed claims of rights. As The Federalist Papers explain, the identity of the judicial branch is pinned to its power of judgment. ${ }^{313}$ The responsibility of making such judgments

309 How persuasive the RAND data are depends on one's views of the ability to assess the effects of rule and practice changes on cases; the problem is controlling sufficiently for the many variables to be confident about isolating specific effects. A related concern is that, given the relatively short time span between implementation of the Civil Justice Reform Act of 1990 and measurement of effects, the impact of changes might not yet have occurred; or alternatively, the culture may have changed before rules and statutes codified those changes, and hence, the time period over which to measure change should have been much greater. See Resnik, Changing Practices, Changing Rules, supra note 22 , at $185-87$.

310 See Rex Bossert, Case Management Gets Judicial Nod: RAND ADR Study Fails to Deter Judges, Who Say More Experiment Is Warranted, NAT'L L.J., June 9, 1997, at A1 I.

311 See Wagshal v. Foster, 28 F.3d 1249, 1252-53 (D.C. Cir. 1994), cert. denied, 514 U.S. 1004 (1995).

312 See id. at 1252; cf. Austern v. Chicago Bd. Options Exch., 898 F.2d 882, 886 (2d Cir. 1990), cert. denied, 498 U.S. 850 (1990) (finding commercial organizations that sponsor contractual arbitration immune from civil liability); see also Butz v. Economou, 438 U.S. 478, 514 (1978) (holding that an executive official performing adjudicative decisionmaking had immunity from suit).

313 See THE Federalist No. 78 (Alexander Hamilton) (Jacob E. Cooke ed., I961). For brief discussion of the import of "merely" in the phrase ("merely the power of judgement"), see note 363 and accompanying text. 
not only specifies the work of a federal judge but also justifies the constitutional protections of the federal judge. ${ }^{314}$ The anxiety engendered by the power so granted is cushioned by judicial obligations of deliberate decisionmaking, explained and accessible to the public, subject to review, and made accountable through appellate processes. ${ }^{315}$

From this vantage point, the federal judiciary has not only succeeded in reinventing the role of the judge, it has also succeeded in undermining its singular claim to constitutional protection. It neither takes life tenure to help facilitate conciliations, nor is it obvious that life tenure should be accorded to the people who attempt to do so. In this respect, Article III may be overprotective of certain forms of judicial "independence," shielding judges who have shifted their focus away from difficult and public decisionmaking.

To push this point further, federal judges begin to appear (oddly) aligned with movements denominated "postmodern." Federal judges may press for settlement because they themselves doubt their own capacities to find information sufficient to call "fact" and are painfully aware of the plasticity of "law." Federal judges act as if they believe that stories dissolve in endless variations, none of which justify the imposition of state power. From this vantage point, federal judges can be understood as encouraging disputants to do as they want, for in these private accords lies as much - or as little - as what adjudication can offer. Judges have, through their practices and doctrine, not only made plain the many facets of the role of judge (judge as settler, judge as negotiator, judge as manager, judge as dealmaker) but also have so deconstructed judging that it is at risk of being undermined as a politically or legally viable concept. ${ }^{316}$

\section{Essentializing Jurisdiction}

The federal judiciary's delineation of its identity by attempting to limit the kinds of cases that the federal courts "should" decide prompts

314 See Gordon S. Wood, The Origins of Judicial Review Revisited, Or How the Marshall Court Made More Out of Less 32-4I (undated) (unpublished draft of the Holmes Devise Lecture, on file with the Harvard Law School Library) (describing earlier efforts by judges to achieve role specificity by distinguishing themselves from the executive through roles "more exclusively legal").

315 Whether such independence is desirable and what forms of accountability should be imposed are questions for another time. See Pamela Karlen, Two Concepts of Judicial Independence, 72 S. CAL. L. REV. 535, 538-49 (1999). For discussion of whether judicial work at settlement can be cabined, see Peter W. Agnes, Jr., Some Observations and Suggestions Regarding the Settlement Activities of Massachusetts Trial Judges, 31 SuFFOLK U. L. REV. 263 (1997).

316 A different kind of concern emerges about the deconstructive role of federal judges if one is intent on federal judicial supremacy but worried about how to maintain it. By encouraging a host of ADR providers, judges (who used to have a monopoly on the provision of judicial services) have helped to launch their competitors and now may have to jockey for what they deem to be the "good cases." See Bryant Garth, From Civil Litigation to Private Justice: Legal Practice at War with the Profession and its Values, 59 BROOK. L. REV. 93 I (1993); see also p. 1009. 
criticism of a different sort, predicated on a mixture of interpretation of the constitutional powers of both the courts and the Congress and contemporary appreciation for the capacious qualities of federalism theory. As described above, federal congresses since the Civil War have pulled an array of topics - from civil rights to labor relations, from health and welfare to guns and education - into the federal net.

The federal judiciary has, in turn, ruled on the scope of congressional authority under the Commerce Clause, the Spending Clause, the Eleventh and Fourteenth Amendments, and how these provisions interact with aspects of federalism theory. Once past the struggles of the New Deal, the Supreme Court generally found that Congress had the power to make an array of issues "federal," thus enabling growth of the federal courts' docket. In the last few years, however, the Court has shifted, concluding in a few decisions that Congress has exceeded its charter either because of Commerce Clause boundaries or because of prohibitions that reside in the penumbra of the Eleventh Amendment, in the vague text of the 'Tenth, or in a more general but non-textspecific constitutional structure. ${ }^{317}$ The federal judiciary as agendasetter has adopted a parallel set of positions, making "policy" arguments that certain problems should not become federal cases but belong to the states. ${ }^{318}$

Here, the very judges who in their settlement mode have veered toward the postmodern (reluctant to fix precise meanings of law and fact and welcoming of multiple and blurred roles) return to essentialist claims when discussing the allocation of cases between state and federal courts - arguing that certain issues intrinsically constitute a "state" as compared to a "federal" case. An example comes from the contemporary controversy over the constitutionality of the Violence Against Women Act (VAWA), ${ }^{319}$ which some federal judges have located as relevant to family law, ${ }^{320}$ and have argued both in case

317 See, e.g., Printz v. United States, 52 x U.S. 898 (1997); Seminole Tribe v. Florida, 5 I 7 U.S. 44 (1996); United States v. Lopez, 514 U.S. 549 (1995). See generally Evan H. Caminker, State Sovereignty and Subordancy: May Congress Commandeer State Officers to Implement Federal Law?, 95 ColUM. L. REV. I00I (1995); Martha A. Field, Garcia v. San Antonio Metropolitan Transit Authority: The Demise of a Misguided Doctrine, 99 HARV. L. REV. 84 (1985); Vicki C. Jackson, Federalism and the Uses and Limits of Law: Printz and Principle, I1 I HARV. L. REV. 2180 (1998).

318 See supra notes 158-160, 2 14-229 and accompanying text.

319 Violence Against Women Act, Pub. L. No. 103-322, 108 Stat. 1941, (codified as amended at 42 U.S.C. \& 13981 (1994)) [hereinafter VAWA]; see Brzonkala v. Virginia Polytechnic Inst. \& State U., 169 F.3d 820 (4th Cir. 1999) (en banc), cert. granted sub nom. United States v. Morrison, i 20 S. Ct. I I (I999).

320 For example, in Brzonkala, the plaintiff, a student, alleged that she had been raped by two football players, one of whom allegedly stated that he liked to "get girls drunk" and then have intercourse with them. Id. at 827 (Motz, J., dissenting). Rejecting congressional power to authorize such federal civil rights actions, the majority relied heavily on the location of family law matters in state courts. See id. at $\mathbf{8 4 2}$ (describing VAWA as aimed at "domestic violence" and then ex- 
law ${ }^{321}$ and in Congress ${ }^{322}$ to be intrinsically a matter for state, not federal, governance.

plaining that while "such violence is not itself an object of family law ... issues of domestic violence frequently arise from the same facts that give rise to issues such as divorce and child custody"). Several other federal courts considering the provision have upheld its enactment as proper pursuant to congressional authority under the Commerce Clause. See, e.g., Ericson v. Syracuse Univ., 45 F. Supp. 2d 344 (S.D.N.Y. I999); Doe v. Doe, 929 F. Supp. 608 (D. Conn. I996).

321 In the U.S., some aspects of family life (marriage, divorce, child custody) are governed by state law but could fall also within certain federal jurisdictional grants, such as diversity. Federal judges developed a "domestic relations" exception to diversity jurisdiction, thus reading out a subset of cases otherwise within federal jurisdiction. The Supreme Court has held, however, that such an exception is based on an interpretation of the diversity statute rather than on a constitutional preclusion. See Ankenbrandt v. Richards, 504 U.S. 689, 706-07 (1992) (rejecting the view that a claim of tortious assault between former family members fits within the exception).

322 In the early 1990s, when the legislation that became VAWA was introduced, the Judicial Conference urged Congress not to create a federal civil rights cause of action when violence against women occurs, but rather to leave responses to the problem to state courts. The judiciary's Office of Impact Assessments issued a statement that such a civil rights provision would generate thousands of cases, "with 13,450 reaching the federal courts at a cost of $\$ 43.6$ million and 450 staff years." Charles Gardner Geyh, Overcoming the Competence/Credibility Paradox in Judicial Impact Assessment: The Need for an Independent Office of Interbranch Relations, in FJC LEGISLATIVE EFFECTS ON WORKLOAD CONFERENCE, supra note 107, at 79, 90 [hereinafter Geyh, Judicial Impact Assessment]. (Note the predicate assumption of such a process - that increased filings are a problem to be mediated. The impact statement did not elaborate the benefits, if any, generated by the cause of action.) That prediction in turn assisted both Chief Justice Rehnquist and the Judicial Conference in cautioning against the proposed cause of action. In his I 991 year-end report, the Chief Justice called for congressional "self-restraint in adding new federal causes of action." Rehnquist, Ig9r Year-End Report, supra note 238, at 3 . He specifically noted that the proposed legislation would impose an unnecessary burden on the federal judiciary and reported that the Judicial Conference and the Conference of Chief Justices of the State Courts opposed the civil remedy in VAWA. See Rehnquist, I991 Year-End Report, supra note 238, at 3 ("The broad defintion of criminal conduct [in the pending VAWA] is so open-ended, and the new private right of action so sweeping, that the legislation could involve the federal courts in a whole host of domestic relations disputes."). The Chief Justice reiterated his concerns in his r 992 YearEnd Report. See Chief Justice Issues 1992 Year-End Report, THIRD BRANCH, Jan. I 993, at I, 3 (describing the judiciary's criticisms of the legislation).

The judiciary's concerns were evidenced by the Conference's creation of an ad hoc committee on Gender-Based Violence. See I991 JUDICIAL CONFERENCE REPORT 47 ("supporting the objectives" of VAWA but objecting to provisions that "significantly threaten the ability of the federal courts to administer this Act, and other Acts of Congress promptly, fairly, and in accordance with their objectives"). The Conference noted its willingness "to work with Congress to ensure the most efficient utilization of scarce judicial resources and to fashion and appropriate response to violence directed against women." Id. at 58; see Victoria F. Nourse, Where Violence, Relationship, and Equality Meet: The Violence Against Women Act's Civil Rights Remedy, I I WIS. WOMEN'S L.J. I, I3 (I996) ("[S]tate and federal judges mounted a campaign to warn that the bill would 'flood the federal courts' and deprive state courts of their traditional jurisdiction.")

Advocates (myself included) argued to individual judges that staking out a position in opposition to federal civil rights legislation addressing women's citizenship rights was not a wise choice for the federal judiciary to make. After much discussion and under the leadership of Stanley Marcus, then chair of the Federal-State Committee of the Judicial Conference, the proposed cause of action was reworded and the Judicial Conference decided not to take a position on the issue of VAWA's civil cause of action. The Conference recorded its support of other aspects of the legislation, which was passed in 1994. See 1993 JUDICIAL CONFERENCE REPORT 28 (stating that "as a result of the dialogue the Ad Hoc Committee [on Gender-Based Violence] has under- 
By essentializing both categories of law and the proper spheres of governance of state and federal courts, such claims reduce each to a caricature. A binary assumption, that an issue is either "state" or "federal," misses the rich complexity of governance, in which shared and overlapping work is commonplace. ${ }^{323}$ Self-conscious avoidance of such an approach should stem from recalling parallel and unsuccessful efforts earlier in the nineteenth and twentieth centuries, when the linedrawing battles were about federal involvement in the regulation of insurance, corporations, labor-management relations, welfare, and family life. ${ }^{324}$ Moreover, efforts to locate violence within familiar re-

taken with the sponsors of the proposed Violence Against Women Act of I99I," the Conference now "takes no position on specific provisions" of the proposed legislation but reiterates its concern about "the trend toward federalization of state law crimes and causes of action"). The Conference believed that provisions "encouraging . . . studies with respect to gender bias" in the circuits had "great merit" and endorced that provision. Id.

As of this writing (six years after the Act), some 50 reported cases address this aspect of VAWA; about $45 \%$ involve factual circumstances arising out of settings that are either commercial or educational. See Brief of Law Professors as Amici Curiae in Support of Petitioners at 13-14 \& n.18, United States v. Morrison (No. 99-5, 99-29) (1999).

323 See Judith Resnik, Federalism's Options, I4 Yale L. \& Pol'y REV. \& Yale J. ON REG. (Symposium Issue) $465,479-92$ (1996). In terms of the specific example of laws related to family construction, federated systems have differing approaches, as is illustrated by Australia and Canada, which locate aspects of family status law in national courts. See M.E.J. Black, The State of the Courts in Australia, FED. LAW. 30, 32 (Jan. 1998); Martha A. Field, The Differing Federalisms of Canada and the United States, 55 LAW \& CONTEMP. PROBS. 107, 108 (1992). See generally Naomi R. Cahn, Family Law, Federalism, and the Federal Courts, 79 IOWA L. REV. 1073 (1994); Anne C. Dailey, Federalism and Families, I43 U. PA. L. REV. 1787 (1995); Resnik, Women, Jurisdiction, and the Federal Courts, supra note 194.

Given my rejection of such essentializing, I read the constitutional powers of the Commerce Clause and the Bill of Rights (including the Nineteenth Amendment as well as the Fourteenth) to permit the national government to regulate a broad range of activities and behaviors. And, on the specific question of the constitutionality of civil rights measures to limit violence against women, ample evidence of which was identified by the Congressional record in VAWA, such aggression directly impinges on women's capacity as economic actors. See Hearing on Domestic Violence: The Need to Concentrate the Fight Against an Escalating Blight of Violence Against Women: Hearing Before the Senate Comm. on the Judiciary, Io3d Cong. I6 (1993) (statement of James Hardeman, Manager, Counseling Department, Polaroid Corp.); Violence Against Women: Victims of the System: Hearing on S. I5 Before the Senate Comm. on the Judiciary, 102d Cong. 239-4I (I99I) (statement of Elizabeth Athanasakos, National President, National Federation of Business and Professional Women, Inc.). Moreover, the regulation of violence targeted at group members is a particularly useful deployment of federal jurisdiction, which offers a means of focusing national attention on the role of violence in sustaining status relationships of inequality.

324 As one commentator put it, "Congress has no power to regulate labor as such." Robert Eugene Cushman, The National Police Power Under the Commerce Clause of the Constitution, 3 MINN. L. REV. 289, 307 (I9I9) (arguing for some form of indirect exercise of such powers). Cushman's essay is reproduced in SELECTED ESSAYS ON CONSTITUTIONAL LAW: BOOK III, THE NATION AND THE STATES 36, 52 (Maurice H. Merrill ed., 1938). See also Jill Elaine Hasday, Federalism and Family Reconstructed, 45 UCLA L. REV. 1297, 1319-55 (1998) (concluding that exclusive localism in family law misdescribed historical practices, and explaining that, during $\operatorname{Re}-$ construction, Southerners viewed slavery as a part of domestic relations law, and that federal law intervened by understanding that the civil rights of newly freed slaves included rights to establish family ties). 
lationships as a part of a legal category "family law" obscure the role of the government in creating family life and licensing violence within its parameters, ${ }^{325}$ as well as the role of violence in marking status within a polity. Ignored in the intimate image of the family is the web of state and federal economic regulations that affect interpersonal relationships. ${ }^{326}$

My goal is to shift the discussion away from constructions of the "essence" of federal power, as if it existed ex ante or were fixed, and toward a different question: is a particular problem one for which judges employed by the federal government could usefully participate in development of national norms? Rather than naturalizing a set of problems as intrinsically and always "federal," I urge an understanding of "the federal" as (almost ${ }^{327}$ ) whatever Congress deems to be in need of national attention, be it kidnapping, alcohol consumption, bank robbery, fraud, or nondiscrimination.

This approach (which I term "non-categorical federalism" ${ }^{328}$ ) does not require that federal judges (life-tenured or not) ignore workload problems. Rather, the advice is threefold: first, Congress should have a presumption in favor of jurisdictional grants vesting concurrently in state and federal courts so as to avoid essentializing either jurisdiction and to seek assistance in norm development from different sets of judges; ${ }^{329}$ second, such grants should be accompanied by resources for both sets of court systems; ${ }^{330}$ and, third, Congress should consider deaccessing categories of cases within the federal docket in which either Congress has not sought national norm development or the work of national norm development has been sufficiently accomplished so that exchanges between state and federal courts have limited utility.

\footnotetext{
325 See, e.g., Reva B. Siegel, "The Rule of Love": Wife Beating as Prerogative and Privacy, 105 YALE L.J. 2117 (I996).

326 See Resnik, Women, Jurisdiction, and the Federal Courts, supra note 194, at 1699 (describing "federal laws of the family" as including federal pension law (in which marital property rules can be found), bankruptcy law (as it interacts with property rights of divorced couples and their children), and welfare, immigration and tax law, all of which are laced with rules depending on family configurations); see also Vicki C. Jackson, Empiricism, Gender, and Legal Pedagogy: An Experiment in a Federal Courts Seminar at Georgetown University Law Center, 83 GEO. L.J. 46r, 479-81 (1994). See generally NiNTH CirCUIT GENDER BIAS TASK ForCE, THE EFFECTS OF GENDER IN THE FEDERAL CoURTS (1993), reprinted in 67 S. CAL. L. REV. 73 I (1994).

327 The question of limits depends in part on how to read the guarantees of the Equal Protection Clause and congressional authority to effectuate those guarantees, as well as on a willingness to understand the breadth of Commerce Clause powers.

328 Resnik, Federalism's Options, supra note 324, at 474-75.

329 Thereby using, indeed celebrating, redundancy. See Robert M. Cover, The Uses of Jurisdictional Redundancy, supra note 170.

330 One such mechanism for facilitating state court funding is the State Justice Institute (SJI), a nonprofit corporation created in 1986 that provides financial assistance to projects that "improve[] judicial administration in State courts of the United States." 42 U.S.C. \& 10702(a) (1994).
} 
Categories plausibly to be eliminated under this formulation include some that might have significant effects on the federal docket (such as diversity litigation) and others in which the numbers of filings are smaller (such as the federal crimes of kidnapping and bank robbery). Diversity jurisdiction is a candidate because, given Erie, federal adjudicatory generativity is limited. Unless Congress provides mandates for federal lawmaking, such cases have (in terms of norm development) a weaker claim for a place on the docket than do other issues. Federal crimes like bank robbery could also be considered for deaccession because little norm development remains to be done; we all believe it is bad to rob banks.

In contrast, "we" - members of this polity - are in deep discord about the rights, wrongs, and import of other behaviors, such as possessing guns, using drugs, and doing physical harm to women. Therefore, until shared norms have been developed and stabilized, federal and state judicial resources can be reasonably and well spent. Under this conceptualization, when Prohibition existed, the federal judiciary was usefully a part of the enforcement mechanism because it provided a venue in which to debate anti-alcohol policies.

Non-categorical federalism shifts the focus from either the dollar value of disputes (to find "important" cases) or their frequency (to sort "garden variety" or "routine" cases from the "exotic"). ${ }^{331}$ Instead, the questions are about the political and symbolic meaning of issues and the work to be done to develop normative commitments. ${ }^{332}$ Noncategorical federalism helps move the tenor of discussion away from claims of hierarchical superiority (with remission of low-value or routine work to non-Article III adjudicators, including state judges) to a focus on the exchange of ideas needed for the process of norm development. The goal is co-venturing, in which federal judges (both constitutional and statutory) are engaged with state judges in adjudication of issues of fact, law, and in-between.

Thereafter, responses other than "don't make a federal case out of it" can be developed to ameliorate workload problems. Given contemporary political efforts to increase state powers, one possibility is to create a federally supported national - but not federal - set of courts for diversity litigation. Further, rather than contemporary proposals

331 See, e.g., Marc Galanter, The Life and Times of the Big Six; or, The Federal Courts Since the Good Old Days, I988 WIS. L. REV. 92 I, 92 I-22, 927 (responding to Justice Scalia's comment that tort cases were a touch of the "mundane" in the federal courts' docket by comparing the percentage of such cases in the 1960 s and the 1980 s and concluding that tort cases have constituted a significant percentage of federal court jurisdiction for many decades).

332 See generally Bourdieu, supra note 7 , at 816-17 (discussing the "juridical field" as a social space in which norms are debated and developed). 
(in both Congress ${ }^{333}$ and the Long Range Plan ${ }^{334}$ ) that multi-party, multi-state mass tort litigation be added to the federal docket, cases could be brought to "national courts" in which judges from several states could sit. ${ }^{335}$ If a conflict centers on disputants from specific states, judges from those states could preside. When conflicts are multi-state (but no federal law governs the outcome), such "national courts" could create rules on the choice of law that look at the degree to which a particular dispute is centered within certain states - instead of contemporary proposals that either federalize state tort law or authorize federal judges to select governing state law. Those courts could then become nationwide institutions of states, like the National Conference of Mayors or the National Association of State Attorneys General. Such multi-state dispute resolution mechanisms could build on the "compact" model currently used by states to engage in a range of joint ventures. ${ }^{336}$ Political theories of federalism permit a variety of arrangements among and between state and federal governments; the suggestion here is that court-based federalism theories, which have thus far damped down experimentation, ${ }^{337}$ be revised.

Non-categorical federalism can help bring to the fore another problem faced by the federal courts but not much discussed: judicial vulnerability to the federal government, which, as the dominant litigant, can by strategic deployment of litigation have great impact. Given federal court budgetary dependence on the government, federal judges should see themselves in need of a varied litigant base to help balance that power. Moreover, given the proliferation of privately based dispute resolution providers and a growing focus on transnational mechanisms for resolution of commercial disputes, ${ }^{338}$ federal judges may find themselves eager to attract certain categories of cases.

Here (shifting from the question of norm development to that of the utility of vibrant and multiple court systems), cases might be selected

333 See Multiparty, Multiforum Jurisdiction Act of 1999, H.R. 967, 106th Cong. (1999) (proposing federal jurisdiction when a "single accident" with at least 25 injured persons causes injuries in excess of $\$ 50,000$ per person, and more than one state is involved through either defendant's residence, different defendants' residences, or the place of accident).

334 LONG RANGE PLAN, supra note I I I, at 3 I n.I6.

335 See Resnik, History, Jurisdiction, and the Federal Courts, supra note 301, at 255-63 (detailing some of the possibilities).

336 See Resnik, Federalism's Options, supra note 324, at 474.

337 Two such examples are the invalidation of the agreement proposed by state governors and enacted by Congress to respond to problems of nuclear waste disposal, see New York v. United States, 505 U.S. 144,149 (1992), and the constraints placed on involving state governments in negotiations with Indian tribes about gambling, see Seminole Tribe v. Florida, 517 U.S. 44,47 (1996).

338 See Geoffrey C. Hazard, Jr. \& Michele Taruffo, Transnational Rules of Civil Procedure, 30 CORNELl INT'L L.J. 493 (1997); Russell J. Weintraub, Critique of the Hazard-Taruffo Transnational Rules of Civil Procedure, 33 TEx. INT'L L.J. 413 (1998). 
for the federal judiciary based on the desirability of building constituencies from diverse sets of litigants and their lawyers, who, as regular users of these courts, see those courts as their own. ${ }^{339}$ Federal judges may need "ordinary" cases as a mechanism to keep a range of litigants interested in the resources and well-being of the federal courts. That caseload could also serve to buffer federal courts from becoming purely statutory and constitutional expositors, inevitably in conflict with Congress, the states, and the executive branch.

The concern about caseload composition requires revisiting the role diversity jurisdiction plays for the federal courts. I relied above on the absence of federal lawmaking as a basis for advocating that diversity jurisdiction be removed from the docket of the federal courts. In contrast, here, precisely because diversity cases arise under state law, they may bring to the federal courts different litigants - "diverse" in today's sense of the word. Whether to support diversity jurisdiction or to propose its diminution or abolition therefore turns in part on an empirical issue: are litigants already familiar with and regular users of federal courts the dominant parties in cases filed invoking diversity jurisdiction, or do a significant proportion of diversity litigants come from a pool of claimants otherwise outside federal jurisdiction?

A final note on these issues: My interest in shifting away from essentialism does not render me a postmodernist advocating deconstitution of the categories of "state" and "federal," while chiding judges for their adoption of too postmodern an attitude toward the judicial role. Holding aside the loose deployment of the "postmodern" that would make its affiliates cringe, ${ }^{340}$ my effort is to take into account the changing contours of demands on adjudicatory systems. What I object to is the refusal to see the political struggles over norm definition as an arena in which federal judges should join state judges in the work of making public, often painful, and occasionally deeply contested, decisions. And, while refusal to take jurisdiction is itself a form of decisionmaking associated with federal jurisprudence, ${ }^{341} \mathrm{I}$ object to judges

339 As the Chief Justice of Maine recently explained, "Courts may have no natural political constituency, but effective communities of lawyers, court users, volunteers, and advocates develop quickly around unmet human needs." Daniel E. Wathem, Lessons Learned Along the Way, STATE-FED. JUd. OBSERVER, Feb. I999, at 3.

340 See Judith Butler, For a Careful Reading, in SEYLA BENHABIB, JUDITH BUTLER, DRUCILLa CORNEll \& NANCY Fraser, Feminist Contentions: A PHILOSOPHICAL ExChaNge I3337 (1995).

341 See AleXander M. BICKel, The Least DaNgerous BRANCH: The Supreme Court at THE BAR OF POLITICS I I I-98 (1962); Gerald Gunther, The Subtle Vices of the "Passive Virtues" - A Comment on Principle and Expediency in Judicial Review, 64 COLUM. L. REV. I (1964); see also Lisa A. Kloppenberg, Avoiding Constitutional Questions, 35 B.C. L. REV. 1003 (1994); Lisa A. Kloppenberg, Measured Constitutional Steps, 7 I IND. L.J. 297 (1996). 
rendering that form of judgment through organizational opposition to congressional conveyance of jurisdiction.

\section{REREADING ARTICLE III}

To this point, the discussion has taken the power of the federal judiciary for granted. Below, I review some of the century's developments from another angle, enabling an understanding of the federal judiciary as a less robust institution. Required from this vantage point is reconsideration of the centrality and some of the presumed virtues of Article III.

\section{A. Vulnerability}

First, consider tensions between Congress and the judiciary. Assessing whether the conflict is greater than in other eras is difficult, as is specifying what forms of interaction to identify as conflict rather than as appropriate exchanges between constitutionally distinct institutions. But at least in some respects, rather than having been transformed into a co-equal branch of government, the judiciary at times seems more like an ordinary agency, petitioning for attention and hoping to achieve the budgetary goals it seeks. Recall the image of a sprawling, multi-tiered judiciary, populated by 2000 judges and 30,000 staff. The federal judiciary, a bureaucratic institution, is heavily dependent on Congress for resources. ${ }^{342}$

Conscious of its needs, the judiciary seems eager to please. While in the earlier decades of this century, the judiciary enjoyed the luxury of submitting a summary statement of its budgetary needs, over the last several years, the federal judiciary has revamped its budgetary processes by creating a special subcommittee, devoted to the issue of economizing; one reason for the restructuring was to improve the ability to demonstrate to Congress that the judiciary shares a concern for cutting costs. ${ }^{343}$ (One federal judge has remarked that the greatest problem facing the federal judiciary is how to pay its rent. The fed-

\footnotetext{
342 For an argument that congressional budgetary largesse for the Supreme Court correlates with enthusiasm for its decisions, see Eugenia Froedge Toma, Congressional Influence and the Supreme Court: The Budget as a Signaling Device, 20 J. LEGAL STUD. 131 (1991).

343 See, e.g., I 998 OPTIMAL UTILIZATION, supra note 97, at 35 (reporting to the Congress on the efforts undertaken by the judiciary "to provide the facilities the judiciary needs to fulfill its mission economically, without impeding the delivery of justice"); see also LONG RANGE PLAN, supra note III, at 148 (discussing, in Recommendation 52, the Economy Subcommittee as analogous to the Office of Management and Budget in the executive branch); Federal Judiciary Requests Smallest Budget Increase in 20 Years for FY 99. THIRD BRANCH, Mar. I998, at I "For the third consecutive year the federal Judiciary has reduced its level of growth in both appropriated funds and total obligations...."). See generally Arnold, supra note 90, at 22 (discussing his views based on chairing the Judicial Conference's budgetary committee).
} 
eral judiciary occupies more than 500 facilities, for which it pays another federal entity, the General Services Administration. ${ }^{344}$ )

Not only does the federal judiciary act much like an agency, it is treated like one by Congress. "Micromanagement" was the term offered by the Chief Justice, ${ }^{345}$ who has also complained about the lack of salary increases. ${ }^{346}$ Congressional oversight can be found in demands for information about courthouse utilization, ${ }^{347}$ judicial hours spent on travel and conferences, ${ }^{348}$ and judiciary support of studies on

344 Three hundred fifty-one federal buildings house courts. Sixty-eight other facilities are post offices with courts; another 289 facilities are leased. See Chart (Nov. 1998), provided by staff at the Office of Space and Facilities Division of the AO (on file with the Harvard Law School Library).

345 See Now the Judges Face the Questions, LEGAL TIMES, Feb. 5, 1996, at 8 (discussing a questionnaire sent by Senator Charles E. Grassley, then chair of the Senate Judiciary's oversight committee, to federal judges and quoting the Chief Justice's concern that, although the survey might aid Congress, it might also "amount to an unwarranted and ill-considered effort to micromanage the work of the federal judiciary"); see also Appellate Survey Results Released, THIRD BRANCH, June 1996 , at 5 .

346 According to one commentator, in 1989 an "unprecedented press conference [was held] at the Supreme Court" to publicize the salary problem, which the release termed "the most serious threat to the future of the Judiciary and its continued operations. " Christopher E. Smith, Judicial Lobbying and Court Reform: U.S. Magistrate Judges and the Judicial Improvements Act of I990, 14 U. ARK. LITTLE ROCK L.J. 163, I73 (I992). Complaints continued during the subsequent years; when ameliorative legislation was enacted in 1997, the Chief Justice began his annual address with an expression of "gratitude to Congress for its financial support of the Judiciary" and gave specific thanks for enactment of a cost of living adjustment (COLA). Rehnquist, 1997 Year-End Report, supra note 238, at I (under heading "Funding, Salaries, Jurisdiction, and Vacancies"); see also Breaking the Freeze on COLAs: An Interview with Judge Barefoot Sanders, THIRD BRANCH, Dec. 1997, at I (discussing Judge Sanders's work as chair of the Judicial Conference Committee on the Judicial Branch, which focused on gaining salary adjustments from Congress); Memorandum of L. Ralph Mecham I (Mar. 23, 1999) (on file with the Harvard Law School Library) (providing a preliminary report of actions taken by the Judicial Conference in its March 16, 1999 session and discussing the resolution of the Executive Committee, which raised concerns about administrative action that increased premiums on life insurance policies for Article III judges).

347 See GeNERAL ACCOUNTING OFFICE, GAO/GGD-97-39, COURTHOUSE CONSTRUCTION: BetTer Courtroom Use Data Could Enhance Facility Planning and DecisionMAKING (1997); Chief Justice Appeals to Congress for Courthouse Construction Projects, THIRD BRANCH, Apr. 1998, at I, I-2 (describing Chief Justice Rehnquist's efforts to convince the House and Senate leadership to support courthouse construction projects); Omnibus Appropriations Bill a Mixed Bag for Judiciary: Omnibus Bill Funds Courthouses in 1999, THIRD BRANCH, Nov. 1998 , at I (discussing the authorization and appropriation of $\$ 460$ million for 13 new projects and another $\$ 25$ million for repairs, and noting the lack of assistance from the White House in obtaining these funds).

348 See GAO Releases Report on Noncase-Related Travel by Judges, THIRD BRANCH, Apr. I998, at 6 (discussing a report, prepared at the request of Senator Grassley, that reviewed the travel of 64 appellate and 254 district court judges and concluded that 3,220 appellate workdays and 9,832 district court workdays were spent on non-case-related trips (such as court meetings or seminars)). Senator Grassley commented: "It is unacceptable for [judges] to engage in this much non-case related travel while at the same time arguing they need more judges ...."Id. The AO responded that judges were appropriately contributing to the legal system through attendance at court meetings and educational programs. See id.; see also SENATE JUDICIARY SUBCOMM. ON ADMIN. 
fairness within the courts. ${ }^{349}$ In addition, the executive branch has attempted to intervene in the courts' budgetary processes, prompting protests from within and without the judiciary. ${ }^{350}$ When faced with inquiries, the judicial administration appears nervous, worried about whether Senator Grassley will send another questionnaire, and eager to avoid confrontations with (at least) this Congress. Rather than protest, it placates. These do not seem to be the days of brave-hearted judges "speaking truth to power." 351

And Congress is not the only source of judicial anxiety; the institution of judging is under attack throughout the country. A wellorganized political campaign has emerged claiming that the judiciary in the United States is too independent. As summarized by the American Bar Association's Commission on Separation of Powers and Judicial Independence in a 1997 report, a "new cycle of intense judicial

OVERSight AND THE COURTS, REPORT ON THE JANUARY I996 JUdICIAL SURVEY, Part I: U.S. Courts of Appeals (Comm. Print 1996).

349 For example, in 1995, Senators Charles E. Grassley, Phil Gramm, and Orrin G. Hatch had a colloquy about "gender bias" or "race and ethnic bias" studies. The Senators put into the Congressional Record that such studies (sponsored by some of the federal circuits) were destructive of judicial independence and should be stopped. See 14I CONG. REC. Si469 I (daily ed. Sept. 29, 1995) (statement of Sen. Hatch). Their objections were made despite explicit congressional encouragement, in a section of the VAWA, 42 U.S.C. $\$ 14001$ (1994), that federal courts undertake such work and listing possible areas of study. Nevertheless, several courts stopped projects for some time to avoid distressing senators who played prominent roles in the judicial budgetary process. See Bruce D. Brown, Judiciary Won't Fight for Court Bias Studies, LEGal TIMES, Nov. I3, I 995 , at $\mathrm{r}$.

350 See Arnold, supra note 90, at 24-25; see also 3I U.S.C. § Iro5(b) (1994); ABA RECOMMENDATIONS, supra note 221 , at IIOB (approving the recommendation that Congress be urged "to authorize the Judicial Branch to submit its annual budget request ... directly to Congress," described as necessary given presidential use of "negative reductions" to affect the judiciary's budget, arguably a breach of the statutory provision that the judiciary's budget is to be submitted "without change"); Judiciary Takes Dual Budget Hits: Budgel Includes Negative Allowance for Judiciary, Nixes Court Construction Funds, THIRD BRANCH, Feb. 1999, at I; Federal Courts Budget Protection Act, S. 1564, 106th Cong. (1999) (permitting the judiciary to submit its budget directly to Congress, thereby bypassing the Office of Management and Budget).

351 Robert M. Cover, The Folktales of Justice: Tales of Jurisdiction, 14 CAP. U. L. REV. 179, I90 (1985). Assessing when judges are unafraid is complex and requires review of judicial decisions in both administrative and adjudicative settings. For example, overturning congressional statutes may bespeak a willingness to "speak truth to power." The contemporary adjudication record includes invalidation of some congressional statutes vesting jurisdiction, as well as acquiescence when Congress has enacted limitations on juridical authority, despite arguable intrusions on the principle of separation of powers. The convergence of substantive goals shared by Congress and the judiciary may explain such willingness by judges to uphold congressional limits on judicial authority. See Mark Tushnet \& Larry Yackle, Symbolic Statutes and Real Laws: The Pathologies of the Antiterrorism and Effective Death Penalty Act and the Prison Litigation Reform Act, 47 Duke L.J. I, 2 (1997) (discussing how "statutory reform and judicial reinterpretation of existing law are alternative ways of revising existing law," but arguing that sometimes, rather than innovate, statutes reiterate judicial law revision and yet may prompt new questions for judicial interpretation). Tushnet and Yackle argue that the 1996 legislation limiting prisoner and habeas litigation exemplifies the later form of legislation, which they term "symbolic statutes," and that such legislation often generates results that are not sensible. See id. at 3-4, 84-86. 
scrutiny and criticism"352 has produced "demagogic attacks" against some judges. ${ }^{353}$ While the ABA's historical review suggests other instances of difficult relations between the courts and Congress as well as attacks on state judges, this time the conversation's tenor is shrill, ${ }^{354}$ and evidence is "mounting . . . not only of a loss of confidence and respect but also a diminished understanding of the role of judges and an independent judiciary in protecting and enforcing the rights of the people." 355

Although the brunt of the problem is borne by state judges, many of whom are elected, ${ }^{356}$ a few life-tenured judges have been targeted. A 1997 political monograph, Impeachment, proposed using the impeachment process not because it would likely succeed but as a "deterrent" to chill judicial decision making. ${ }^{357}$ In the fall of 1997 , a federal district judge in Pennsylvania granted a habeas corpus petition; thereafter, 30,000 people signed a petition calling for his impeachment. ${ }^{358}$ In short, segments of the body politic are railing against certain judges and judicial power in general.

Contemporary debates about the legitimacy of judicial power and attacks on individual judges require a return to the constitutional text, to the words of Article III that create the federal judiciary. In conversations about judicial independence, a common assumption is that Article III is not only a paradigm of independence but (with its guarantees of life tenure and protected salaries) also the pinnacle of how such independence can be achieved. Yet in terms of separation of powers, Article III appears thin; it provides only for life tenure and individual salary protection ${ }^{359}$ and ignores the institutional needs of a judiciary

\footnotetext{
352 AMERICAN BAR ASS'N COMM'N ON SEPARATION OF POWERS AND JUdicial INDEPENDENCE, AN INDEPENDENT JUDICIARY at $\mathrm{i}$ (1997).

353 Id. at 46.

354 See id. at ii.

355 Id. at vii. Thereafter, the ABA sponsored a survey and reported that, while "confidence" in the justice system remained strong, particularly in the U.S. Supreme Court, levels of confidence on specific issues varied by gender, race and ethnicity, and by income levels of respondents. See AMERICAN BAR ASS'N, PERCEPTIONS OF THE U.S. JUSTICE SYSTEM 6-13 (Feb. 1999).

356 See Stephen B. Bright, Political Altacks on the Judiciary, 80 JUDICATURE 165 (1997).

357 See DAVID BARTON, IMPEACHMENT: RESTRAINING AN OVERACTIVE JUDICIARY 53 (monograph circulated in 1997) (on file with the Harvard Law School Library). Further discussion of a programmatic effort to limit federal judicial authority can be found in Edwin Meese III \& Rhett DeHart, Reining in the Federal Judiciary, 80 JUDICATURE I 78 (1997).

358 See Joseph Slobodzian, Did This Judge Free a Killer?, NAT'L L.J., Nov. 3, I997, at A6 (describing a petition signed by 37,000 residents of Lancaster County, Pennsylvania).

359 How much protection is a much-litigated issue; questions include the relationship between the calculation and payment of cost-of-living adjustments and the non-diminution clause of Article III. See United States v. Will, 449 U.S. 200 (1980) (involving cost-of-living adjustments for Article III judges during a four-year period); Williams v. United States, 48 F. Supp. $2 d 52$ (D.D.C. 1999) (granting summary judgment on behalf of a class of Article III judges who argued the un-
} 
functioning in the administrative state either as a branch of government or as a provider of services to the thousands of litigants that seek its attention. ${ }^{360}$ Article III protects no budgets, no buildings, and few, if any, jurisdictional grants. ${ }^{361}$

The interactions between Congress and the federal courts rely on the goodwill of both branches. ${ }^{362}$ Traditions of inter-branch accord have generally protected the federal judiciary, whose coffers are relatively full and its prerogatives relatively respected. But there are no guarantees. As the judiciary reinvents and transforms itself, it is ever more reliant on Congress - for staff, for funding for surrogate and subsidiary judges, for its very ability to do its work. However attractive at the founding were the limited protections within Article III, 363 they do not now (if they ever did) significantly insulate the judiciary from the other government branches. While such dependency may be a viable mode for a judiciary in a democratic society, the rhetorical reliance on Article III as cleverly calibrated to solve the problem of judicial authority is no longer plausible.

\section{B. Irrelevancy}

Article III is sparse from another perspective. Return to the needs for federal adjudication, now provided by some 2000 judges (statutory

constitutionality of application of a statute, barring automatic salary adjustments, to Article III judges who had received such adjustments under the Ethics Reform Act of 1989 ).

In 1982 , a group of federal judges founded an "independent, voluntary" organization, the Federal Judges Association, to "lobby" for federal judicial salaries. As explained by one of those founders:

From the early I970s through the mid-1980s, this nation experienced the greatest threat in its history to the quality and independence of the federal judiciary as uncontrolled inflation reduced the compensation of federal judges. Congress refused to make adjustments for these losses....

Spencer Williams, Foreword to Carole Hicke, The Federal Judges Association: A DECADE OF ACHIEVEMENT, I982-I992 at vii (9th Judicial Cir. Historical Soc'y I992).

360 A point obvious to the judiciary. See LONG RANGE PLAN, supra note III, at 155 ("Recommendation 57: Congress should be encouraged to include appropriations for the constitutionally mandated functions of federal courts as part of the non-discretionary federal budget.").

361 The degree to which Congress can control jurisdiction and the degree to which original and appellate jurisdiction vest in either the Supreme Court or the lower federal courts is a subject of much debate. See, e.g., Akhil Reed Amar, A Neo-Federalist View of Article III: Separating the Two Tiers of Federal Jurisdiction, 65 B.U. L. REV. 205 (1985); Gerald Gunther, Congressional Power to Curtail Federal Court Jurisdiction: An Opinionated Guide to the Ongoing Debate, 36 STAN. L. REV. 895 (1984); Lawrence Gene Sager, The Supreme Court, 1080 Term - Foreword: Constitutional Limitations on Congress' Authority to Regulate the Jurisdiction of the Federal Courts, 95 HARV. L. REV. 17 (1981).

362 See generally John Ferejohn, Independent Judges, Dependent Judiciary: Explaining Judicial Independence, 72 S. CAL. L. REV. 353 (1999) (discussing the conditions under which the agreement of mutual cooperation between the courts and Congress can be undone).

363 See THE FEDERALIST No. 78, supra note 313 (advocating - depending on how one reads the word "merely" in "merely the power of judgment" — such thin protections). 
and constitutional) within the Article III branch and a larger number sitting in administrative agencies. As discussed, the life-tenured judiciary's (re)reading of Article III to permit judges who lack life tenure to make decisions has been a useful adaptation. ${ }^{364}$ The elasticity of Article III doctrine, with its now-expansive definition of who can hold the federal power of judging, enables disputants to obtain adjudicatory decisionmaking in their encounters with the administrative state.

Further, magistrate judges provide a neat solution to the current battles over judicial selection. While appointees to life-tenured judgeships may have to wait until the Senate is willing to think about them, ${ }^{365}$ magistrate judge appointees do not. And while their positions are not life-tenured, the high reappointment rate ${ }^{366}$ provides an incentive for those interested in judging to choose the magistrate judge route over either nomination or state-based election. In addition, the Article III judiciary's reliance on magistrate judges avoids interactions with Congress that could prompt inquiry about life-tenured judges' workload and allocation of time as well as provide opportunities for political theater. ${ }^{367}$ But the judgeships thus manufactured lack, by definition, Article III protections.

What is the import for Article III theory of the swelling ranks of such judges? First, their existence diminishes the importance of life tenure, which is no longer essential for many exercises of federal adjudicatory power, successfully delegated to a carefully selected group of statutory judges. Presumptive validation of the abilities of magistrate and bankruptcy judges comes from the high rate of their reappointment; further evidence of fungibility awaits a range of empirical studies, such as whether reversal rates of and appellate comment on decisions rendered by statutory Article III judges vary significantly from those of decisions rendered by constitutional Article III judges, and information on the perceptions of litigants, lawyers, and judges about the differences between the two kinds of judges. But even without such evidence, the promotion by the life-tenured judiciary of non-life-tenured judges (ironically) provides Congress with an intelligible and presumptively apolitical rationale for thinning the

\footnotetext{
364 See supra pp. 988-90.

365 See Lee Renzin, Advice, Consent, and Senate Inaction - Is Judicial Resolution Possible?, 73 N.Y.U. L. REV. 1739, 1745-48 (1998).

366 See Conversation with staff at Magistrates' Division of the AO (Nov. 19, 1999) (describing a reappointment rate of more than $90 \%$ ).

367 See, for example, the debate about the seats on the Fourth Circuit, supra note 242, and the tensions in the hearings on whether a vacancy would be filled on the D.C. Circuit, 143 CoNG. REC. S2 5 15-36 (1997) (debates on the nomination of Merrick B. Garland, of Maryland, to be U.S. Circuit Judge for the District of Columbia).
} 
ranks of life-tenured judges. ${ }^{368}$ Why create expensive judgeships when less expensive judgeships will do?

Second, while not much evidence thus far suggests that Congress targets individual magistrate and bankruptcy judges, the administrative judiciary appears vulnerable at both the individual and institutional level. ${ }^{369}$ Because many administrative law judges enjoy civil service protections, the concern is less about judges being fired and more about pressures visited on administrative law judges by colleagues within an agency. ${ }^{370}$ Moreover, Congress has recently used its power to refuse to continue funding of the Administrative Conference; ${ }^{371}$ the demise of this institution limits the ability of administrative law judges to enhance a collective sense of the import of their role. ${ }^{372}$ These problems, associated with the administrative judiciary, may migrate to the statutory judiciary located within Article III, which is another means by which Congress could increase the dependency of the Third Branch on the First.

368 Proponents of more federal judgeships currently complain that Congress has not, despite pending legislation based on the judiciary's requests, provided new life-tenured judgeships since 1990. See I45 CONG. REC. S6288-89 (daily ed. May 27, 1999) (statement of Sen. Leahy) (introducing the Federal Judgeship Act of 1999). Not all congressional incentives support the use of magistrate judges in lieu of district judges. Constitutional judicial appointments require congressional acquiescence. In contrast, magistrate judges are appointed by district judges, and thus, as the ranks of magistrate judges grew, congressional control over the selection process of judges became attenuated. See DEBORAH J. BARROW, GARY ZUK \& GERARD S. GrYSKI, THE FEDERAL JUDICIARY AND INSTITUTIONAL CHANGE I I-24 (I996) (discussing partisan efforts to shape the federal judiciary, the complexities of the effects of divided control of the presidency and Congress, and the utility of a larger constitutional judiciary for presidents interested in affecting its direction).

369 See Steven G. Calabresi \& Kevin H. Rhodes, The Structural Constitution: Unitary Executive, Plural Judiciary, I05 HARV. L. REV. I I55, I I 72-74 (1992) (discussing Congress's “formidable" power to create non-Article III courts).

370 Such concerns prompted repeated attempts during the I 980 s to alter the structural protections for administrative law judges. See, e.g., S. 826, 102d Cong. (I99I) (creating a unified corps of administrative law judges in lieu of keeping those judges a part of individual agencies); S. 673, 99th Cong. (1985) (same); Administrative Law Judge Corps Act, S. 1275, 98th Cong. (1983) (same). The history of these efforts is set forth in Gerald E. Ruth, Unification of the Administrative Adjudicatory Process: An Emerging Framework to Increase "Judicialization" in Pennsyluania, 5 WIDENER J. PUB. L. 297, 317-20 (I996). For discussion of ambivalence towards administrative law judges' independence from agencies, the problems of docket overload, reliance on decisionmakers other than administrative law judges, and the tension between "management control and decider independence," see Verkuil, supra note IOI, at $1353-63$.

371 See William Funk, R.J.P. A.C.U.S., ADMIN. \& REG. L. NEWS, Winter I996, at I, I, II (describing the termination of funding to the Administrative Conference of the U.S., which studied agency processes - including adjudication - and proposed improvements).

372 Similar battles over the existence and funding of the State Justice Institute suggest that Congress does not have a robust commitment to projects that support judiciaries, be they state, federal, or tribal. See Malcolm M. Lucas, Don't Pull the Rug Out From Under the State Justice Institute, LEGAL TIMES, Sept. 25, 1995, at 21 (describing efforts to "kill" the institute, which funds grants to state justice systems and facilitates the sharing of information about innovative programs). 
Third, the diminished centrality of life-tenured federal judges risks reduction of judicial political capital. Because the federal system relies on structural protections of life tenure and salary guarantees to symbolize that judges are important (and because judges with these attributes continue to monopolize the title "federal judge"), those "other" federal judges are inferentially less significant. Given insufficient public financial support of courts in general, when Congress focuses its support on such "lesser" judges, Congress may be signalling that the status of judging is of decreasing social import - or trying to make it less important.

Increasing the ranks of the life-tenured is one response to such problems, but improvement need not depend exclusively on insistence that Congress make federal judgeships only if life-tenured. An alternative is to explore how to equip non-life-tenured federal judges with qualities comparable to those imported through life tenure so that the exercise of federal adjudicatory authority continues to be undertaken by individuals with the sense of authority, élan, and social significance that is presumed to enable wise and deliberate decisions. ${ }^{373}$ Even if statutory judges do not have life tenure, one wants them to act with comparable authoritative independence. This effort requires changes by many actors, including both the constitutional and statutory judiciary.

Life-tenured judges could help by revising their adjudicatory rulings and shifting administrative policies. For example, life-tenured judges could reread Article III to condition the transfer of adjudicatory authority on a concomitant transfer of some forms of structural independence. Such a reading of the Constitution would imbue the exercise of federal adjudicatory power with independence and would require that any person holding the federal power of judgment be insulated from certain forms of attacks. Translating those aspirations into practice would, for example, require new doctrine to protect statutory federal judges from dismissal based on the rate of decisions; certain kinds of pressures, such as directives to resolve cases in a particular fashion, would also be barred as a matter of constitutional law.

Additionally, sources other than Article III could serve to shore up the independence of those federal judges who adjudicate outside its contours. Some equipage may come from due process mandates for impartiality, ${ }^{374}$ from common law doctrines such as immunities from suit, and from the amalgam of constitutional and common law rights that guarantee access to the public for some adjudicatory proceedings.

\footnotetext{
373 Not all theories of authority require a sense of social superiority; the focus is on developing an understanding of the significance of the event of judging and marking that act through ritual.

374 See Henry P. Monaghan, Constitutional Fact Review, 85 ColUM. L. REV. 229, 250-54 (1985).
} 
If all kinds of federal judges are required to make decisions impartially and openly, if the public has a presumptive place in the process (be it located in courts or agencies), if judges know that they have special protections from litigants unhappy with rulings but that hierarchically superior judges would subject decisions to careful review, then perhaps those first-tier judges (many of whom do make rulings on contested claims rather than settle cases) will make more careful, more deliberate, and better reasoned judgments.

Revisiting doctrine may thus help to ensure that the iconic status of judging is shared with the many sub-Article III judges who make decisions of serious consequence to disputants. Such expansive doctrinal work could help to generate forms of "cultural capital" for non-lifetenured judges so that they see themselves (and can be seen by others) as significant actors, obliged to be deliberate in and accountable for their decisionmaking. But doctrine is not the only space in which Article III judges work. For non-life-tenured judges to become centrally important decisionmakers, Article III judges would have to retreat from their own claims of cultural superiority and to support public investments to mark the import of these "other" judges.

For example, if part of the rationale for judicial independence rests on the public aspect of judicial work, "courts" in agencies provide little opportunity for such interaction. Cases are heard in hearing rooms with neither space nor plan for public attendance. Decisions by many administrative law judges and by hearing officers are not routinely available to the public and can be found - if at all - through laborintensive scrutiny of transcripts or court files. To shift administrative law judges away from alignment with the invisible bureaucracy and toward affiliation with the symbolism of personalized judgments made in courts, the spaces currently occupied by such judges would have to be reorganized. Indeed, the conception of bureaucracy as inherently demeaning has to be revisited to conceive of ways to produce large numbers of similar judgments without ignoring the individual issues that form the basis of the conflict. As for the statutory judiciary within Article III, magistrate and bankruptcy judges fare better in terms of courtroom space and support but they have not been embraced by the governance structures of the Article III judiciary as actors fully a part of the judicial process. ${ }^{375}$

375 For example, none serves as an official member of the Judicial Conference. See 28 U.S.C. 833 ( 1994 ) (providing for membership by district and appellate judges). The difference between the proposed recommendation in the draft Long Range Plan to increase governance authority of non-Article III judges and the recommendation adopted in the revised plan illustrates the reticence of Article III judges to share their markers of status. Compare COMMITTEE ON LONG Range Planning, Judicial Conference of the United States, The Proposed long RANGe PIAN FOR THE FEDERAL COURTS: DRAFT FOR PUBLIC COMMENT 64-65 (I994) (pro- 
In short, much work must be done to take some of the equipage that belongs to the life-tenured federal judges and to high-level state court judges and to expand its reach to include lower-tier federal, state, and administrative judges. To do so requires a retreat from a singular focus on life tenure and an embrace of non-Article III judges as fully credible judicial actors. These first-tier judges, in turn, need to reorient themselves to bring the public into their work. In certain respects, such an undertaking echoes the efforts earlier in the twentieth century to professionalize the judiciary, in terms of both enhancing its administrative capacity and changing the behavior of lower-echelon judges, whose jobs were not held in high esteem. Just as the proponents of pretrial case management invented judicial education to teach new judges to assume a new role, so must those of us who believe in judging articulate and teach all tiers of judges to merit and to use an independent judicial role. This project also entails a claim that judging - a specific form of state-imposed intervention in conflicts generated by members of the polity - remains a vital part of the legal and political regime.

\section{CACOPHONy, For a PECULIAR BRANCh of GOVERnMENT}

Revisiting the corporate culture of Article III as it has developed over this century is also in order. Two particular aspects are at issue - reliance on collective action and selection of substantive agendas related to the federal courts' jurisdiction. Return to the propositions that I asserted above: that, as an educational and rulemaking organization, the federal judiciary has adopted an anti-adjudication and prosettlement agenda; and that, as a lobbying organization, the federal judiciary has chosen to oppose the creation of new federal rights and to support delegation of many tasks of life-tenured judges to other

\footnotetext{
posing, as recommendation 49c, that "Non-Article III judges should be afforded the opportunity for meaningful participation in governance," including that the "Judicial Conference should include one bankruptcy judge and one magistrate judge designated by the Chief Justice" to serve terms equal to those of district court judges and that circuit judicial conferences do so as well), with LONG RANGE PLAN, supra note II 1 , at 84-85 (recommending, as number 5oc, that the federal judiciary provide for "meaningful participation in governance" by non-Article III judges but suggesting only that the Board of the Federal Judicial Center include such judges and that individual districts take "appropriate steps" for inclusion). See generally Smith, supra note 346, at 163-83 (detailing what the author terms magistrate judges' "struggle for status and authority" and conflicts with district judges about markers of status, such as whether magistrate judges may be addressed as "judge" and may wear robes).

Bankruptcy and magistrate judges do play some role currently in governance. Some of the committees of the Judicial Conference include bankruptcy and/or magistrate judges, as well as an occasional lawyer or law professor as either a member or reporter.
} 
judges. ${ }^{376}$ For several reasons, such statements ought to be - but are not - incoherent.

\section{A. Representation}

One critique is that the internal mechanisms by which the judiciary "speaks" are structures of authority not representative of the judges within. ${ }^{377}$ One basis for such an argument comes from contrasting contemporary practices with those of earlier generations in which, for example, life-tenured judges often polled their siblings before taking public positions and, when learning of dissent, retreated from specific proposals.

The problem of representation is also highlighted by the development of an etiquette opposed to dissents. Seeking success on Capitol Hill, the federal judiciary discourages judges from "breaking ranks" with positions taken by the Judicial Conference. ${ }^{378}$ Relatively few judges testify before Congress to offer views contrary to the judiciary's official policy; controversy within judicial circles erupts when they do. ${ }^{379}$ Thus life-tenured judges work within the confines of their own

\footnotetext{
376 See supra pp. 982-83; 987-92.

377 Surveying of members of the judiciary continues, but on an episodic basis. See, e.g.,
} Federal Judicial Center, Planning for the Future: Results of a 1992 Federal JudiCIAL CENTER SURVEY OF UNITED STATES JUDGES at iii (1994) (describing a survey of "nearly all federal judges on a wide range of issues of concern to the federal courts" to provide information to the Judicial Conference's Long Range Planning Committee and to facilitate responses to congressionally mandated studies). The FJC has also provided an overview of governance questions, including the problem of unequal representation of appellate judges because of the differing sizes of the circuits, disproportionate representation of appellate judges (as contrasted with district judges) on the Judicial Conference, and the absence of representation of the statutory judges. See RUSSELL R. WHEELER \& GoRdON BERMANT, FEDERAL COURT GoverNANCE: WHY CONGRESS Should - ANd Why Congress Should Not - Create a Full-Time Executive Judge, ABOLISH THE JUDICIAL CONFERENCE, AND REMOVE CIRCUIT JUdGES FROM DISTRICT COURT GOVERNANCE (FJC 1994) (discussing the many governance issues implicated); id. at $4 \mathrm{I}-50$ (considering the problem of unequal representation of appellate judges because of the differing sizes of the circuits, disproportionate representation of appellate judges (as contrasted with district judges) and the absence of representation of statutory judges); Kramer, supra note 119 , at 81-89 (arguing for better planning through an agency equipped to assess judicial workload and legislative effects); see also Geyh, Paradigm Found, supra note 127, at 124 - 40 (proposing an "Interbranch Commission on Law Reform and the Judiciary" to monitor legislation affecting the judiciary and to propose statutes to the related courts).

378 See, e.g., AO Director Henry Chandler, Speech at Circuit Conferences (June 1947), in Judicial Conference Committee Records, supra note 50, at Box 25. In his discussion, Chandler described the respect due individual judges' judgments but concluded that

it would seem that when legislative policies have been determined after full opportunity for consideration by all concerned, and are favored by a large majority of the judiciary, individual members might be willing to refrain from opposition except in matters of conscience or fundamental principle. Respect for the collective opinion of the judiciary Id. may be more important than the particular issue.

379 See, e.g., The Civil Justice Reform Act of 1900 and the Judicial Improvements Act of 1990: Hearings on S. 2027 and S. 2648 Before the Senate Comm. on the Judiciary, 1orst Cong. 208, 
bureaucratic structure, with perks such as travel and committee assignments flowing to the well-regarded. The effort to instill discipline into federal judges by encouraging them to speak with one voice limits the polity's ability to glean information from their diverse experiences of purposefully individualized adjudicatory processes. Lost are some of the third-party benefits derived from licensing independent actors to do such work.

\section{B. Substantive Goals}

A different criticism addresses the substance of the Judicial Conference's statements. Even if the Judicial Conference is licensed to speak as a collective, are the specific proposals of jurisdictional retrenchment ones that judges ought to promote? One might argue that, given docket pressures, an anti-jurisdiction posture is inevitable. Relying on a kind of essentialism about judicial bureaucracies, one could read the Long Range Plan as a collective expression of judges, crying for help. Pulling together to avoid becoming ineffective, they plead for congressional self-restraint in an effort to protect the power and integrity of courts by guarding their gates.

But the specific proposals of the current federal corporate judicial culture (to limit rights-seeking within its courts) are not intrinsic to contemporary judicial collectives. Evidence of alternatives comes from state courts, most of which have also developed institutions of governance and planning. ${ }^{380}$ Many state court programs and "futures plans" differ from those fashioned by the federal judiciary. While sharing enthusiasm for alternatives to adjudication, several state judiciaries have undertaken projects that promote access to courts and welcome litigants rather than close doors. ${ }^{381}$ The state courts have led

232-77 (testimony of Richard A. Enslen) (speaking in favor of S. 2027, about which the Conference had taken a different position); see also FISH, supra note 20, at 305-I 1 (describing earlier efforts to bypass the Judicial Conference and to lobby Congress directly).

380 See generally IRA PILCHEN \& SANDRA RATClifF, AMERICAN JUdicatuRE SOC'Y, ConDUCTING STATE COURT FUTURES ACTIVITIES (1993); DATOR \& RODGERS, supra note III. The SJI, discussed supra notes 330,372 , has provided assistance for many of these projects.

381 See, e.g., Brickley, Michigan Judicial Reform, supra note 296, at II3I. In the report, Michigan's chief justice described the "basic values" of that court's system as including responsiveness to the "changing needs of Michigan's citizens"; accountability to the public for use of resources; and fair treatment and accessibility "in a convenient and affordable forum." Id. (emphasis omitted); see also CHIEF JUSTICE's COMM'N ON THE FUTURE OF THE COURTS [MASS.], REINVENTING JUSTICE 2020, at II-34, 43-50 (1992) [hereinafter MASSACHUSETTS'S ReINVENTING JUSTICE] (describing its central themes to be "user-oriented justice," "multi-option justice," "public trust and confidence," "equal justice," and "justice for all"); COMMISSION ON THE FUTURE OF THE CAL. Courts, Justice IN THE BalanCE 2020, at 55-69 (1993) [hereinafter CaliforNia COURTS' FUTURE] (providing a chapter entitled "Access to Justice" and discussing language, cultural, and physical barriers to courts, as well as a role for the judiciary in developing programs to enable greater access to legal representation for the middle class as well as the poor); COMMission on Justice in the TWENTY-First CENTURy, "DOING UTAH JUSTICE": A PROGRESS 
efforts to consider the effects of race, gender, and ethnicity on judicial processes; court-empowered commissions have been forthright in reporting failures of fairness. ${ }^{382}$ Several state judiciaries are also working to increase the interaction between legal and social services for segments of litigants (including those involved with intra-family conflict and misuse of drugs) ${ }^{383}$ and to improve the availability of legal services (for both the poor and the middle class), again in an effort to enhance access to justice. ${ }^{384}$

How great a difference in emphasis between state and federal judiciaries can be debated; ${ }^{385}$ how much the difference in agendas derives

RePORT TO THE PEOPLE OF UTAH 32-36 (1991) (providing recommendations to enhance public access to courts); COMMISSION TO STUDY THE FUTURE OF MAINE'S COURTS, NEW DIMENSIONS FOR JUSTICE 24-3I (1993) [hereinafter MAINE COURT STUDY] (beginning with a discussion of "Public Voice and Customer Focus" and calling for the institutionalization of means by which "judicial leadership can keep in touch with public perspectives"); Shirley S. Abrahamson, The Challenge: The Consumer and the Courts, in DATOR \& RODGERS, supra note I I I, at I23-28 (calling for evaluation of courts from the perspective of their users and discussing efforts in Wisconsin to reach out to citizens); John F. Daffron, Jr., The Challenge: Future Thinking and the Process of Preparing for Change, in DATOR \& RODGERS, supra note III, at III-12 (describing "responsive[ness] to the needs of the public" as a central goal of Virginia courts' work and describing how that mission grew out of a specially appointed commission of diverse participants charged with identifying such goals).

382 See, e.g., CALIFORNIA CoURTS' FUTURE, supra note 381, at 71-100 (discussing perceptions of unequal treatment and the need for responses); CoMmission ON WASH. TRIAL COURTS, FINAL REPORT 63 (1990) ("The Commission supports the goals of the Gender and Justice Task Force and the Minority and Justice Task Force. The Commission believes that the courts should continue to work towards eliminating even the appearance of bias in the courts on the basis of gender or race."); Resnik, Women, Jurisdiction, and the Federal Courts, supra note I94, at 1685-90 (discussing state court leadership of such court-based programs and the initial reluctance of the federal courts to undertake comparable projects); see also Lynn Hecht Schafran, Documenting Gender Bias in the Courts: The Task Force Approach, 70 JUDICATURE 280, 289-90 (1987); Lynn Hecht Schafran, Gender Bias in the Courts: An Emerging Focus for Judicial Reform, 21 ARIZ. ST. L.J. 237,25 I-60, 267-7I (1989).

383 See CALIFORNIA COURTS' FUTURE, supra note 381 , at 39-40 (explaining that a true public system of justice connects human services and court services); COMMISSION ON THE FUTURE OF The TenN. JUdicial SyS., To SERVE All PEOPLE 5 I (1996) [hereinafter TENNESSEe's CoMMISSION] (calling for more collaboration between family courts and social services); id. at $61-63$ (arguing that the judicial system needs to go "beyond ... clearing its own docket" and to "play a part in actually solving the problems that arrive before it"); MAINE COURT STUDY, supra note 381, at 62 (calling for "closer coordination" among courts, criminal justice processes, and mental health, educational, and human services).

384 See MASSAChUSETTS'S REINVENTING JUSTICE, supra note $38 \mathrm{I}$, at 46-48; CALIFORNIA COURTS' FUTURE, supra note 381 , at $64-68$. The SJI has also supported a national conference on "unrepresented litigants" in an effort to improve methods of court-based assistance. See STATE JUSTICE INST., FINAL GRANT GUIDELINE, FISCAL YEAR I998, at 25 (I997); see also IOWA SUP. COURT COMM'N ON PLANNING FOR THE 2 IST CENTURY, CHARTING THE FUTURE OF IOWA'S COURTS 56-59 (1996) (discussing the roles of clerks and courts when litigants represent themselves).

385 Some consideration of public confidence and access can be found in the Judicial Conference's LONG RANGE PLAN; the ninth of I I chapters is entitled "The Federal Courts and Society," and includes recommendations and discussion about equal and affordable justice, as well as legal services and a "customer service orientation." See LONG RANGE PLAN, supra note II I, at I 7 I-88. 
from differences in methods of judicial selection is unclear; and how much the two sets of institutions should have disparate attitudes toward their own missions is a matter of political and legal theory. A diminished focus on public needs may, for example, be a less attractive artifact of life tenure. The lesson for my purposes here is that judicial corporate culture facing increasing workload demands has the capacity to develop a range of attitudes about the role and function of courts and about how to express those purposes to the public. ${ }^{386}$ The form chosen by the federal judiciary is not inevitable.

Yet other defenses of the contemporary Judicial Conference stance are available. The Long Range Plan could be seen as the parallel, at the national level, to the shift in the daily practices of judging, discussed above. Conversing with Congress, the judiciary is broadening the range of topics it takes up in an effort to shape its docket, just as individual judges as case managers now talk with litigants informally about the many ways to conclude disputes. And, just as proponents of multifaceted roles for individuals argue that the impartiality of judging is not compromised by such new tasks, so might advocates of federal judicial jurisdictional lobbying claim that judicial neutrality can be maintained. An anti-jurisdiction approach proposes to limit access no matter which political interests benefit from the jurisdictional provisions Congress might have generated. Further, because Congress can do what it wants, no harm comes from judicial efforts to press Congress in any particular direction. ${ }^{387}$

\section{Forms of Action}

The next question is whether the collective voice itself is a problem; even if representative structures within the federal judiciary sufficed

\footnotetext{
However, the federal court planning committee was comprised exclusively of judges. See id. at 235-37. In contrast, many state planning commissions followed the advice to "include the public at large as soon as possible in the process." PILCHEN \& RATClifF, supra note 380 , at 9 (emphasis omitted). Public representatives sat on most of the committees. See, e.g., CaliforNIA COURTS' FUTURE, supra note 381 , at v-vi; TENNESSEE'S COMMISSION, supra note 383 , at $\mathbf{x}-\mathbf{x i}$. Further, in contrast to the first goal of the federal courts - limiting jurisdiction - the opening premises of many of the state projects focus on courts' interactions with the public. See, e.g., MAINE CoURT STUDY, supra note $38 \mathrm{r}$, at 3 ("Convenience to the public is to be emphasized rather than the preferences of judges and the legal community.").

386 See, e.g., HEYDEBRAND \& SERON, supra note 60, at $215-16$ (describing a "democratic model of justicen and contrasting its attitudes and predicates with other models).

387 For discussion of how judicial domination of civil rulemaking has facilitated a perception of judicial partisanship, thereby weakening judicial authority in Congress, see Yeazell, Judging Rules, Ruling Judges, cited above in note 41 at $240-4 \mathrm{I}$; and Geyh, Paradigm Found, cited above in note 127 , at $1211-14$. On the other hand, Judicial Conference policy has commanded congressional respect. See FISH, supra note 20, at 69-70 (discussing the weight that members of Congress were willing to give to recommendations of the Conference of Senior Judges in the Ig2os, and quoting the view of one Congressman that any recommendation from such a body was presumptively "proper and fitting and necessary" (citations omitted)).
} 
(either through polling or by formal means of election), and even if the content of the programs of the judiciary differed or were themselves appropriate, should such statements issue? To explore this problem, consider the Chief Justice's 1999 complaint that by not constricting federal court jurisdiction, Congress has failed to implement the recommendations of the Long Range Plan. In recent speeches, the Chief Justice argued in support of his position that the Judicial Conference's Plan "is based not simply on the preferences of federal judges, but on the traditional principles of federalism that have guided this country throughout its existence." $388 \mathrm{He}$ cited Presidents Abraham Lincoln and Dwight Eisenhower as expositors of these principles. ${ }^{389}$

Hold aside the questions of what attitudes either Lincoln or Eisenhower had on federal jurisdiction and their relevance, if any, to contemporary debates. Focus instead on the choice made by the highest officer of the federal judicial administrative apparatus. $\mathrm{He}$ invoked the legacy of two presidents to argue that because their views paralleled those of the judiciary's Long Range Plan, Congress has all the more reason to retreat from its grants of federal jurisdiction.

One could just dismiss this example as only political rhetoric and as unsurprising rhetoric from a man long identified with efforts to narrow the role of the federal courts and in some respects Congress. ${ }^{390}$

388 William H. Rehnquist, Criteria for Federal Jurisdiction Needs to Be Preserved in Assessing Proposed Legislation, STATE-FED. JUD. OBSERVER, Feb. I999, at 2; see also AMERICAN LAW INST., REMARKS AND ADDRESSES 13-19 (May I1-14, 1998) [hereinafter Rehnquist, 1998 ALI Remarks].

389 The Chief Justice said:

[T]he long-range plan is not based simply on the preferences of federal judges but on the traditional principles of federalism that have guided this country throughout its existence. It is a principle enunciated by Abraham Lincoln in the Igth century, and Dwight Eisenhower in the 2oth century: Matters that can be adequately handled by the states should be left to them; matters than cannot be so handled should be undertaken by the federal government.

Rehnquist, $1998 \mathrm{ALI}$ Remarks, supra note 388 , at 17. The Chief Justice singled out the juvenile crime bills, the Anti-Car Theft Act of 1992, the Violence Against Women Act of 1994, the Freedom of Access to Clinic Entrances Act of 1994, the Child Support Recovery Act of 1992, and the Animal Enterprise Protection Act of 1992 , as well as "recent arson provisions," as examples of expansion of federal jurisdiction, and commented that:

I can't say categorically that any of these bills don't pass the Lincoln-Eisenhower test, but one senses from the context in which they were enacted that the question of whether Id. at 18 . the states are doing an adequate job in this particular area was never seriously asked.

390 See, e.g., Garcia v. San Antonio Metro. Transit Auth., 469 U.S. 528, 579 (1985) (Rehnquist, J., dissenting) (claiming that he was "confident" that, in time, his position that Congress lacked the power to require states to comply with the Fair Labor Standards Act would "again command the support of a majority of this Court"); Wainwright v. Sykes, 433 U.S. 72 (1977) (limiting federal court review via habeas corpus); see also Jeff Powell, The Compleat Jeffersonian: Justice Rehnquist and Federalism, 9 I YALE L.J. I 317 (1982); Mark Tushnet, A Republican Chief Justice, 88 MICH. L. REV. 1326 (1990) (reviewing SUE DAVIS, JUSTICE REHNQUIST AND THE CONSTITUTION (rg89)). In some of his speeches, the Chief Justice has himself considered the question of the pro- 
Yet the claim made comes on behalf of the Article III judiciary and my task is to explain why - independent of its content - I think it wrong to proffer jurisdictional views on behalf of that institution. ${ }^{391}$

Imagine that instead of an anti-rights approach, the speech had a pro-access rhetoric, urging Congress to enlarge the jurisdiction of the federal judiciary so as to make available the pursuit of more rights within its purview. Or take an example from the judiciary's archives about remedial authority; in the late I 960 s, a committee of the Judicial Conference suggested that, while the death penalty was "primarily" an issue of "policy to be determined by Congress ... the death penalty with certain exceptions should be abolished." 392 A third example comes from the I $980 \mathrm{~s}$, when the Judicial Conference opposed legislation aimed at limiting its authority. ${ }^{393}$ In my view, neither the Chief Justice as the spokesperson for the judiciary nor the Judicial Conference as the official incarnation of the Article III judiciary should advise Congress to create new jurisdictional provisions and causes of action, to impose or to abolish the death penalty or other statutorily authorized remedies, to keep specific jurisdictional provisions, or to stop generating causes of action. Individual judges and ad hoc collectives of judges might want to express their views on these issues, and judges must rule in cases raising them, but the Article III judiciary

priety of judicial comment to Congress and, occasionally, counseled against it. For example, despite the long history of Judicial Conference commentary on sentencing, see supra note 135 , and its pivotal role in framing the Youth Corrections Act, see supra note 293, the Chief Justice stated that: Whether the scheme of federal sentencing should emphasize deterrence as opposed to punishment, what is an appropriate sentence for a particular offense, and similar matters, are questions upon which a judge's view should carry no more weight than the view of any other citizen. In such cases I do not believe that the Judicial Conference, or other judicial organizations, should take an official position. . . . There is certainly no formal inhibition on judges publicly stating their own personal opinions about matters of policy within the domain of Congress, but the fact that their position as a judge may give added weight to their statements should counsel caution in doing so.

Chief Justice Rehnquist Reflects on 1904 in Year-End Report, THIRD BRANCH, Jan. I 995, at I, 3. In contrast, he continued his speech by describing

considerable sentiment in the federal judiciary at the present time against further expansion of federal jurisdiction into areas which have been previously the province of state courts enforcing state laws. ... Congress, of course, is the ultimate arbiter of these questions within constitutional limits, but the future shape and contours of the federal courts is surely a legitimate subject for judicial input to Congress."

Id. at 3-4.

391 See also Lauren Robel, Impermeable Federalism, Pragmatic Silence, and the Long Range Plan for the Federal Courts, 7 I IND. L.J. 84I, 842, 849-5I (I996) (contesting "every element" of the Plan's understanding of federalism and arguing that such proposals are inappropriate for the judiciary to make).

392 Report 62 , in JUdicial CONFERENCE RECORDS/AO COLLECTION, supra note 50, at Binder 196 gess. ("A motion to table this recommendation carried."); see Ig69 JUDICIAL CONFERENCE REPORT 62.

393 See 1983 JUDICIAL CONFERENCE REPORT 58-59 (discussing H.R. 46, 98th Cong. (1983), the enactment of which the Conference "strongly opposed"). 
should not present such agendas to the polity and use its authority to advance particular positions.

Why? A separation of powers objection is available, here resting on concern about judicial encroachment on congressional prerogatives through efforts to influence jurisdictional legislation outside of and in addition to rulings on specific cases raising jurisdictional questions. My argument depends on a conception of Article III as requiring not only disinterested adjudication by individual judges, but also a disinterested stance by the institution of judges towards the topics that provide the subject matter of adjudication. ${ }^{394}$ My approach also requires the view that construction of statutes creating the Judicial Conference to authorize such commentary does not solve the constitutional problem. Whether attempting to work as effective political rhetoricians or responding to requests for advice, lobbyists acting in the name of the Article III judiciary have what I believe to be an unconstitutional edge - the ability to adjudicate as a means of pressing their vision of wise policy. And, for me, cabining and distributing powers remains attractive in a constitutional democracy, structured by a text embodying obligations of self-restraint.

But more needs to be excavated to make such formalist claims persuasive. The express commitment of the federal judiciary (and the Constitution) to independence in adjudication is in tension with the ethos of contemporary federal judicial culture that insists on unity in support of programmatic goals. The threat from the "bureaucratization" of the federal judiciary comes not from having a larger number of judges or from creating institutional structures per se but from the ways in which such institutions and the many judges within them function. ${ }^{395}$ A group of judges, achieving positions of prominence through a mixture of seniority and personal skill at institutional politics, now purport to speak for the judiciary on jurisdictional issues that have spawned hundreds of rulings (with varying outcomes) over the past two hundred years.

Unlike adjudication, with its fragmented quality, however, the judiciary's bureaucratic leaders select certain views as the judiciary's goals, thereby limiting the authority of other judges who may have different opinions but lack a corporate platform. The ninety-three recommendations of the official "Long Range Plan" of the federal judiciary quiet the cacophony, here desirably discordant, that is generated

\footnotetext{
394 Cf. Geyh, Paradigm Found, supra note 145, at $1193-94$ (arguing that "judges acting as administrators or individuals are simply unaffected by the limits Article III places on courts").

395 Whether delegation and diffusion of decisionmaking are problematic for judges prompted an exchange between Owen M. Fiss and Patricia M. Wald. Compare Owen M. Fiss, The Bureaucratization of the Judiciary, 92 YALE L.J. 1442 (1983) [hereinafter Fiss, Bureaucratization], with Patricia M. Wald, Bureaucracy and the Courts, 92 YALE L.J. 1478 (1983).
} 
by judicial opinion writing within a common and constitutional law tradition. This institutionalization of ideas results in stultified postures that become difficult to revisit.

A justification for judicial independence is that it enables an unaffiliated set of decisionmakers to rule among competing claims advanced by special interest groups. Judges with their own policy statements to promote become just another special interest group. Although judges have long been seen as affiliated with governing elites, that identity derived from the selection of judges by political processes, coupled with their education, class, and professional associations - factors thought to produce certain worldviews. But judges were only able to express whatever allegiances they in fact felt through adjudication, which is episodic, erratic, and lacking in enduring programmatic capacity.

Adjudication licenses independent judges to respond to particularized conflicts by rendering judgments, which other judges and/or legislatures may then revisit. Each decision lays the groundwork for the next, prompted by varying factual settings and statutory predicates. Momentary unification occurs when the Supreme Court decides a case, but the illusion of fixed rules is soon made plain by the next fact pattern pushing - for example - the meaning of the word "case" in Article III, the concept of standing, the implication of causes of action, or the boundaries of the Commerce Clause, and prompting an opinion that alters issues presumably settled by an earlier decision. As the composition of the Supreme Court and lower courts changes, the same questions play out in different contexts, with an array of judges constantly (re)shaping not only federal judicial power but also the content of the rules created by that power. Instead of this redundant, dynamic, generative, and messy process, the federal judiciary's leadership has issued a codified program to persuade Congress to enact or to repeal certain laws. Through that codification, the political processes lose input from clusters of judges with views different from those of the Judicial Conference.

The adjudicatory process also suffers grave losses from the judiciary's commitment to undertaking programmatic work. Each opinion is at risk of being perceived to be in (or out of) sync with federal judicial policy; each decision can be read as forwarding the vision of the Judicial Conference or as attempting to shift that policy. Moreover, an opinion becomes a second platform for such policymaking. For example, when judges invalidate jurisdictional statutes (such as the Violence Against Women Act) or when they narrowly construe remedial provisions of the Americans with Disability Act and thereby make federal courts less attractive venues for such cases, are they acting in accordance with individual judgments on the legality and meaning of particular constitutional or statutory phrases? Or are they taking into account federal judicial policy goals and using a case as a vehicle to 
implement those goals without having to persuade Congress? Moreover, Congress is not the only audience; opinions become modes by which judges talk to each other not about a given legal doctrine but about the federal judiciary's policy.

My concern here is not about delegation of judicial task, fragmentation of role, impersonal action, or irresponsible judging. ${ }^{396}$ Rather, it is about programmatic judging, undertaken by a judiciary taking too much responsibility for the long-term shape of its docket through both administrative and adjudicative means and thereby undermining both the legitimacy of adjudication and the constitutional allocation of authority among branches of governance. The disinterested judge imagined in constitutional and popular rhetoric is now a part of an organization that is increasingly identifying its own interests, goals, and programs. The fact of this collective enterprise is a problem not much examined as the administrative apparatus propels itself forward, focusing first on the allocation of judgeships, expanding to redefine who can judge, how to judge (or avoid judging), and then aspiring to define what is to be judged.

Such unity of action is plainly effective; to reduce the emphasis on speaking with a unified voice requires a willingness to retreat from being a player on the Hill lobbying jurisdictional platforms. Such a retreat does not require that judges never propose legislation relating to courts, ${ }^{397}$ and it neither precludes the judiciary from reporting that demands for work exceed capacity nor truly insulates judicial adjudicatory activities from interaction with judges' administrative roles. Because my focus is on policy positions proffered in the name of the Article III judiciary and because these positions provide responses to constitutionally based interpretive questions about the interaction between Article I and Article III, I do not offer a catalogue of what forms of collective commentary on issues other than jurisdictional and remedial authority are appropriate. Of course, such line-drawing is complex. As illustrated by efforts to draw distinctions between substance and procedure, context is critical. Moreover, on either side of whatever line is drawn will come matters of social import.

396 Cf. Fiss, Bureaucratization, supra note 395 , at 1458 (discussing the "Rule of Nobody" in a judiciary in which judges delegate so much that they have too little personal responsibility for their judgments); Patrick E. Higginbotham, Bureaucracy - The Carcinoma of the Federal Judiciary, 3 I ALA. L. REV. 26I, 269 (I980) (arguing against the proliferation of "mini-judges").

397 How they participate is now a matter of debate. See, e.g., John P. Frank, The Rules of Civil Procedure - Agenda for Reform, I37 U. PA. L. REV. 1883 (1989) (arguing that judicial lawmaking in procedural rules is both cumbersome and out of sync with contemporary issues); Geyh, supra note $35 \mathrm{I}$, at $1234-40$ (proposing the creation of a free-standing agency specially focused on the needs of courts but not a part of the judicial branch); Kramer, supra note I I9, at 78-97 (proposing an agency to assist Congress in evaluating the needs of the judiciary, allocating courts' services, and proposing law reform). 
Yet the rough boundary proposed here (do not comment, as the Article III judiciary, on jurisdiction and remedies) could provide a guideline and could construct a sense of constraint, both of which are currently lacking. Thus, the burden of this essay has been to examine why jurisdictional commentary is particularly unwise but not to insist that all judicial involvement in court-related problems cease. My optimism about the potential for change comes in part from experience with federal judicial activities in procedural rulemaking; just as the enthusiasm in the r93os for trans-substantive rules has given way to a preference for rules distinguishing among cases, ${ }^{398}$ so could assertions in the I 990 os that the federal judiciary can comment on its jurisdictional mission cede to an understanding that some forms of judicial commentary have harmful effects.

The example of rulemaking with which this essay begins offers two other insights: that judicial involvement in policy formulation can be accompanied with self-discipline about boundaries and that, nonetheless, adjudication may well be expected about the legality of whatever choices are made. Those insights in turn prompt yet additional advice, echoing concerns now articulated about judicial over-involvement in procedural rulemaking. The Article III judiciary should structure even its permissible collective action inclusively (welcoming the participation of constitutional and statutory federal judges, as well as of nonjudges) to avoid judicial domination of policy decision-making about issues affecting courts. ${ }^{399}$

What is required is a rejection of the aspiration for judicial unity when the judiciary is functioning as an administrative unit, advising Congress about rights and remedies. In its stead should come acceptance of highly idiosyncratic judicial bureaucracies, designed to make

\footnotetext{
398 Examples of legislative and judicial efforts are plentiful. In 1976, Congress enacted rules governing habeas petitions under 28 U.S.C. \$2254 and \$2255. See Rules Governing \$2254 Cases in the U.S. District Courts, Pub. L. No. 94-426, 90 Stat. 1334 (r976) (codified after 28 U.S.C. $\$ 2254$ ); Rules Governing $\$ 2255$ Cases in the U.S. District Courts, Pub. L. No. 94-426, 90 Stat. I334 (I976) (codified after 28 U.S.C. $\$ 2255$ ). The MANUAL FOR COMPLEX LITIGATION, providing special practice guidelines for courts and attorneys involved in complex litigation, was first published in 1969 and has since been updated in 1985 and again in 1995. See MANUAL FOR COMPleX Litigation (I969); MANUAL FoR CoMpleX Litigation, SECOND (I985); MANUAL FOR COMPLEX LITIGATION, THIRD (I995). In 1995, Congress enacted two statutes that created special rules for prison litigation and private securities litigation. See Prison Litigation Reform Act of 1995, Pub. L. No. I04-134, I 10 Stat. 1321 (1995) (codified at I8 U.S.C. \$ 3626; 28 U.S.C. $\$ \S$ I346(b), I9I5, I9I5A; and 42 U.S.C. I997); Private Securities Litigation Reform Act of I995, Pub. L. No. 104-67, rog Stat. 743 (I995) (codified at I5 U.S.C. $\$ 78 \mathrm{u}-4$ ).

399 Judges could be usefully involved in rnaking rules of procedure, for example, but the meaning of such rules and their legality are sometimes at issue in litigation. See, e.g., Burbank, supra note 23. For discussion of the harms flowing from the increased control of rulemaking by federal judges, see Yeazell, Judging Rules, Ruling Judges, supra note 41, at 229, 232-37 (objecting to judicial domination of civil rulemaking and arguing for revisions to produce a system of "judicially scrutinized rules" rather than "judicially crealed rules").
} 
themselves limited, if not dysfunctional, as interest group lobbies. Rather than proffer univocal statements about jurisdiction under the banner of Article III, the judiciary should facilitate means by which individual judges, or groups of judges - experienced in a particular area, with knowledge and potentially conflicting views to share - offer their ideas to Congress and to others concerned about the constitutional and political parameters of the jurisdiction and remedial powers of the federal courts. I use the word cacophony to invoke and embrace the potential that once such dissents are permitted and encouraged, discordant sounds may echo as the debate about federal judicial authority is enriched. .00

Multiple voices may be less persuasive to Congress and to other judges, but they make available a wider range of ideas about the possible purposes of federal adjudication and the roles available to the many kinds of judges who do the work. On display would be the fact of judicial independence, enacted by judges - with and without life tenure - in disagreement about the utility and justice of particular provisions of law. Once the door to dissent is open, understandings of what constitutes "good judging" (which now prizes dispositions over dissertations) may also shift. The educational course offerings that currently privilege case management might be accompanied by some that reflect on jurisprudence and the meaning of the judicial role. Dissent - emblematic of the jurisprudential work of judges committed to struggling over how to generate law from fact and what meaning to attribute to events - would become an attribute of the judicial institution itself. In short, a great deal of reorientation is required and, for such alternative cultures of judging and concepts of judicial organizations to be created, energetic reformers will be needed in the new century, as they were in the old.

\section{THE ICONIC COURTHOUSE}

Concluding discussions suggest that a story has an end. Millennium studies notwithstanding, ${ }^{401}$ the close of the twentieth century is

400 One example of such helpful dialogue comes from an essay written by the Chief Judge of New York State's courts and disagreeing with proposals on the LONG RANGE PLAN. See Judith S. Kaye, Federalism Gone Wild, N.Y. TIMES, Dec. I3, I994, at A29 (objecting to a proposal in the November, 1994 draft of the federal judiciary's LONG RANGE PLAN that federal courts divest themselves of most diversity jurisdiction as well as jurisdiction over whole categories of civil and criminal cases). Chief Judge Kaye argued that, because this work would revert to state courts, which are also concerned about docket congestion, the proposal failed to take into account the needs of all judges. See id.

401 See generally STEPHEN JAY GOULD, QUESTIONING THE MILlENNIUM: A RATIONALIST'S GUIDE TO A PRECISELY ARBITRARY COUNTDOWN (1997). 
not a reason to provide tidy surnmations. ${ }^{402}$ This essay has considered what federal judges say when they write opinions, make rules, teach other judges, give speeches, present policy papers, testify before Congress, and act collectively. I have shaped a century-long narrative of the transformation of the role of trial judge into that of manager and settler, of the transformation of courthouses into office buildings, and of the transformation of the Third Branch into an administrative agency, sometimes scoring impressive gains and sometimes seeming vulnerable. Each month brings another chapter, making closures artificial.

Yet one more aspect of the federal courts' practices remains to discuss: what the federal judiciary does when constructing buildings called "courts." Within the last few years, the federal government has embarked on what has been termed an "ambitious" program of courthouse construction, with more than 150 projects - some renovations, some new buildings - underway or recently completed. ${ }^{403}$ In the fall of 1998 , I participated in a symposium in conjunction with the opening of one of these new federal courthouses, constructed in Boston for the District of Massachusetts and for the First Circuit Court of Appeals. ${ }^{404}$

Judges from those courts guided the committee that chose architect Harry Cobb, who designed a ten-story building with a huge conoid of glass that forms one wall of the courthouse and that dominates the public space by permitting views of the floors above. ${ }^{405}$ (See photos I and 2). The commission for the building's art went to Ellsworth Kelly, who created twenty-one panels of varying colors. ${ }^{406}$ The design committee preferred the nonrepresentational colored panels to overtly didactic images of scale, swords, and Justicia, which are traditionally associated with justice buildings. ${ }^{407}$

402 Such summations are usefully avoided on other occasions as well. $C f$. STEPHEN GREENBLATT, MARVElous POSSESSIONS 2 ( $199 \mathrm{r}$ ) (preferring "petites histoires" to "totalizing, integrated, progressive" history).

403 See Landecker, supra note 97 , at $68-95$ (describing some of the 156 building projects, including renovations).

404 See Symposium on the Art and Architecture of Civic Buildings: A Symposium to Celebrate the Opening of the U.S. Courthouse, in Boston, Mass. (Sept. 24, 1998) (program) (on file with the Harvard Law School Library).

405 See Woodlock, Judicial Responsibility, supra note 99, at 67; Douglas P. Woodlock, Architecture and the Design of the New Federal Courthouse in Boston (Lecture for the Boston Society of Architects 1994-I995 Lecture Series, Jan. 25, 1995) at 22, 25-26 (manuscript on file with the author) [hereinafter Woodlock, The New Federal Courthouse in Boston].

406 Under the Art-in-Architecture program, the General Services Administration "allocates up to one half of one percent of the estimated construction cost" of a federal building for commissioned art. See General Servs. Admin., U.S. Courthouse, Boston, Mass.: The Artwork 2; General Servs. Admin., The Boston Panels: Ellsworth Kelly, U.S. Courthouse (pamphlet prepared in conjunction with the display of Kelly's art in the courthouse) (on file with the Harvard Law School Library).

407 See generally Dennis E. Curtis \& Judith Resnik, Images of Justice, 96 YALE L.J. 1727 (I987). According to participants in the Boston project, our point - that the symbolism associated with justice had become popularized to the degree that its meanings were diluted - affected 
Upon entering, one can glimpse on the floors above more than two dozen arches, each marking the entry to a courtroom. Twenty-five of those courtrooms are for the trial court; ${ }^{408}$ those rooms are in many ways as conventional as the conoid glass wall is distinctive. (See photo 3). The judge's bench is on the back wall, appearing a bit lower than is common, in a self-conscious effort to portray law as accessible. The witness box sits in front of another wall, the jury box in front of another, and the public in front of the fourth wall. Each wall of the district judges' courtrooms has its own arch of equal height to suggest the equality of all participants before and in law, as well as the attention due to each. 409

The builders of this courthouse chose the arches and the courtrooms as central icons of their building. ${ }^{410}$ As I looked at these lovely rooms, softened by a stencilled design inspired by other New England

their decisions on the building's iconography. See Hon. Douglas P. Woodlock, Comments at the Symposium on the Art and Architecture of Civic Buildings (Sept. 24, 1998) at $5-6$ (transcript on file with the Harvard Law School Library). The designers might have been leery of representational imagery that might have provoked controversy about the images chosen. Ellsworth Kelly's panels offered a kind of safe haven, described by one commentator at the symposium as landscapes and portraits, waiting to be inscribed. See Robert Campbell, Comments at the Symposium on the Art and Architecture of Civil Buildings 54 (Sept. 24, 1998).

In addition to the panels, a series of inscriptions, carved onto inside and outside walls of the courthouse, provide additional opportunities for education. See FEDERAL COURT PUBLIC EDUCATION Fund, The ART and Craft of Justice: A Guide to the Stone Carvings and INSCRIPTIONS OF THE U.S. COURTHOUSE IN BOSTON (1998) (hereinafter THE ART AND CRAFT OF JUSTICE] (pamphlet distributed in conjunction with the courthouse's opening) (including scripts and explanations of each quotation). The courthouse was also built to serve as a venue for civic education, and a range of programs are now underway. See Boston Bar Ass'n, The Federal Court Public Education Project (report sponsored by the Boston Bar Association and the Boston Bar Foundation) (spring 1999) (on file with the Harvard Law School Library); General Servs. Admin., U.S. Courthouse, Boston, Mass., Boston Bar Association Alliance (undated) (pamphlet) (describing the establishment of a Federal Court Public Education Fund); General Servs. Admin., U.S. Courthouse, Boston, Mass., Courts and Community (undated) (pamphlet) (on file with the Harvard Law School Library) (describing planned programs for outreach to the community).

408 Six of these courtrooms are for magistrate judges, whose courtrooms, see supra p. 952, are somewhat smaller than those of district judges.

409 See Woodlock, The New Federal Courthouse in Boston, supra note 405, at 28-29.

410 As one of the judges active in the planning explained, a design challenge was how to construct a building that "affirm[ed] the singular importance of the courtroom when multiplying the number of spaces claiming that name and yet diminishing the portion of the building devoted to that space." Id. at I8. The building's architect, Harry Cobb, noted that the "whole enterprise lof courthouse construction] is devalued by being wrapped by hundreds of thousands of square feet of bureaucratic space." Ziva Freiman, Shoring up the Center, PROGRessive ARCHITECTURE, Apr. 1993, at 84, 88; see also Landecker, supra note 95, at 67 ("Architects are struggling to build courthouses without devaluing the individual courtroom."). Also central to the didactic mission of the courthouse are the inscriptions in stone tablets, designed to "commence a dialogue." Woodlock, The New Federal Courthouse in Boston, supra note 405, at 18-2 I; see also THE ART AND CRAFT OF JUSTICE, supra note 407. 
courthouses, ${ }^{411}$ I thought about the trial rate of the federal district courts. In the District of Massachusetts in 1998, about four civil cases out of one hundred completed a trial; 412 including criminal trials, about 180 trials (bench or jury) were held in 1998 , or no more than about seven per courtroom. ${ }^{413}$ Of course, a range of activities occur in courtrooms other than trials, ${ }^{414}$ but I also thought again of the local rules of the District of Massachusetts - of their insistence that, at every meeting with lawyers, judges promote disposition of cases by "settlement or other alternative dispute resolution programs."415

The federal judiciary has been eager to transform the processes of judging, yet its buildings bespeak an allegiance to adjudication. The new federal courthouse in Boston eschews "old fashioned" justice symbolism and leaves behind representational depictions in favor of glass walls and richly colored Kelly panels. The symbols central to the 1998 building, however, are the exterior and interior arches of courtrooms, fashioned not as conference rooms but as if juries and judges were therein regularly rendering judgments on disputed questions of law and fact. 416

Federal judges are not the only people ambivalent about leaving adjudication behind. Even as this generation's energetic visionaries promote "alternative dispute resolution" as a better way to respond to

411 See Discussion with members of the First Circuit (Aug. 1998); see also Woodlock, The New Federal Courthouse in Boston, supra note 405, at 10 (describing the stenciling in the Barnstable County Courthouse and in the Taunton Courthouse).

412 For the District of Massachusetts, of 3263 civil filings, 142 completed a trial. Of the 3105 cases terminated, 84 did so during or after trial, for a rate of about $2.7 \%$. See Administrative Office of the U.S. Courts, Judicial Business of the United States Courts, at supp. tbls.C-3, C-4A, and C-7 (I998) (visited Jan. 5, 2000) <http://www.uscourts.gov/dirrptg8/index.html>.

413 This estimate is low because the District of Massachusetts holds court in Springfield and Worcester, as well as in the new courthouse in Boston. On the other hand, when trials occur, many last longer than did trials of decades ago. For example, in 1998, of civil cases tried to completion in the District of Massachusetts, $33 \%$ took a day; $16 \%$ two days, $6 \%$ three; $35 \%$ four to nine days; and $9 \%$ took ten or more days. See Administrative Office of the U.S. Courts, Judicial Business of the United States Courts 181 tbl.C-8 (1998) <http://www.uscourts.gov/dirrpt98/ index.html>. Nationally, $44 \%$ of civil cases took a day; $16 \%$ two days; $13 \%$ three days, $24 \%$ four to nine days, and $4 \%$ more than 10 days. See id. In contrast, in $1984,46 \%$ took one day, $33 \%$ two to three days, $19 \%$ four to nine days, and $3 \%$ more than ten days. See Resnik, Failing Faith, supra note 292, at 560 app.B tbl.2, "Estimated Length of Civil Trials."

414 In the more than 3100 civil cases ended in the District of Massachusetts during the year, judges may have used courtrooms for hearings on contested motions or for other purposes. See I 998 ANNUAL REPORT OF THE ADMINISTRATIVE OFFICE OF THE U.S. COURTS I69 tbl.C-4A. Further, as of October 1997,819 criminal defendants had cases pending in the District of Massachusetts, and proceedings related to these cases required courtroom use. See id. at 204 tbl.D-I.

415 See DIST. MASS. LOCAL R. 16.4(A). This rule is discussed above in note 3.

416 The new federal courthouse in Portland, Oregon, does include a mediation or conference room, tucked in on each courtroom floor behind the courtrooms and not easily accessible to the general public. Courthouse tour (Mar. I5, 1999). 
disputes, ${ }^{417}$ they rely on the familiar images of judging. A leading academic proponent calls for a multi-doored courthouse, ${ }^{418}$ and many private providers market "justice services." 419 Some of the higher-paid private providers are themselves former judges, now retired, finding a growing demand for work by someone who bears the title "judge."420

Through their building projects, the leaders of the judiciary demonstrate their own ambivalence about the justice system they have created. They seek to invoke images of the judicial branch, which (in the words of one of the planners of the new courthouse in Boston) is "unlike any other government agency," because it "treats each citizen before it not as a member of a group, but as a separate and individual human being," and it devotes time "to the particular individual's specific problem." 421 Similarly, through their appropriation of the language of judging, proponents of alternative dispute resolution rely on the powerful hold that adjudicatory processes have on the polity.

I began this essay by invoking a federal judge who called trials evidence of a "failure of the system." I linked his voice to rules and practices evolving over the past six decades, and then to projects of the corporate judiciary that have altered the practices of judging and the culture of the judiciary. I close by invoking another judge's voice, also heard in the rggos. He wrote a short essay arguing that the word "judge" is a "verb as well as a noun." 422 Maybe he is also not alone.

417 See Resnik, Altemative Dispute Resolution and Adjudication, supra note 33.

418 See Sander, supra note 305, at 13 I (describing the concept). This piece was published as a part of Sander's contribution to the National Conference on the Causes of Popular Dissatisfaction with the Administration of Justice, 70 F.R.D. 79 (1976).

419 These sources include "Rent a Judge" in California and "JAMS/EndDispute." "JAMS" is an acronym for "Judicial, Arbitrator, Mediator, Services, Inc." Who Is JAMS? (visited Oct. 8, 1999) <http://www.jamsadr.com/whoisjams> (describing itself as the "nation's leading full-service provider of dispute resolution services," and employing both "attorney-neutrals" and former judges).

420 One such organization is FedNet, created by former federal judges, including Thomas Lambros, who retired after serving as Chief Judge of the U.S. District Court for the Northern District of Ohio. Some 30 former federal judges are affiliated, either as shareholders or as ADR providers. See FedNet, FedNet to Open Its Doors with Reception in Big Apple (Dec. I, I998) (Press Release) (on file with the Harvard Law School Library); Telephone Interview with FedNet's Director of Operations (Mar. 5, 1999).

421 Woodlock, The New Federal Courthouse in Boslon, supra note 405, at II (quoting Justice Stephen Breyer).

422 William R. Wilson, Jr., Where Has All the Civility Gone?, ARK. TRIAL LAW. Ass'N DockET, Summer 1990 , at 5 . 


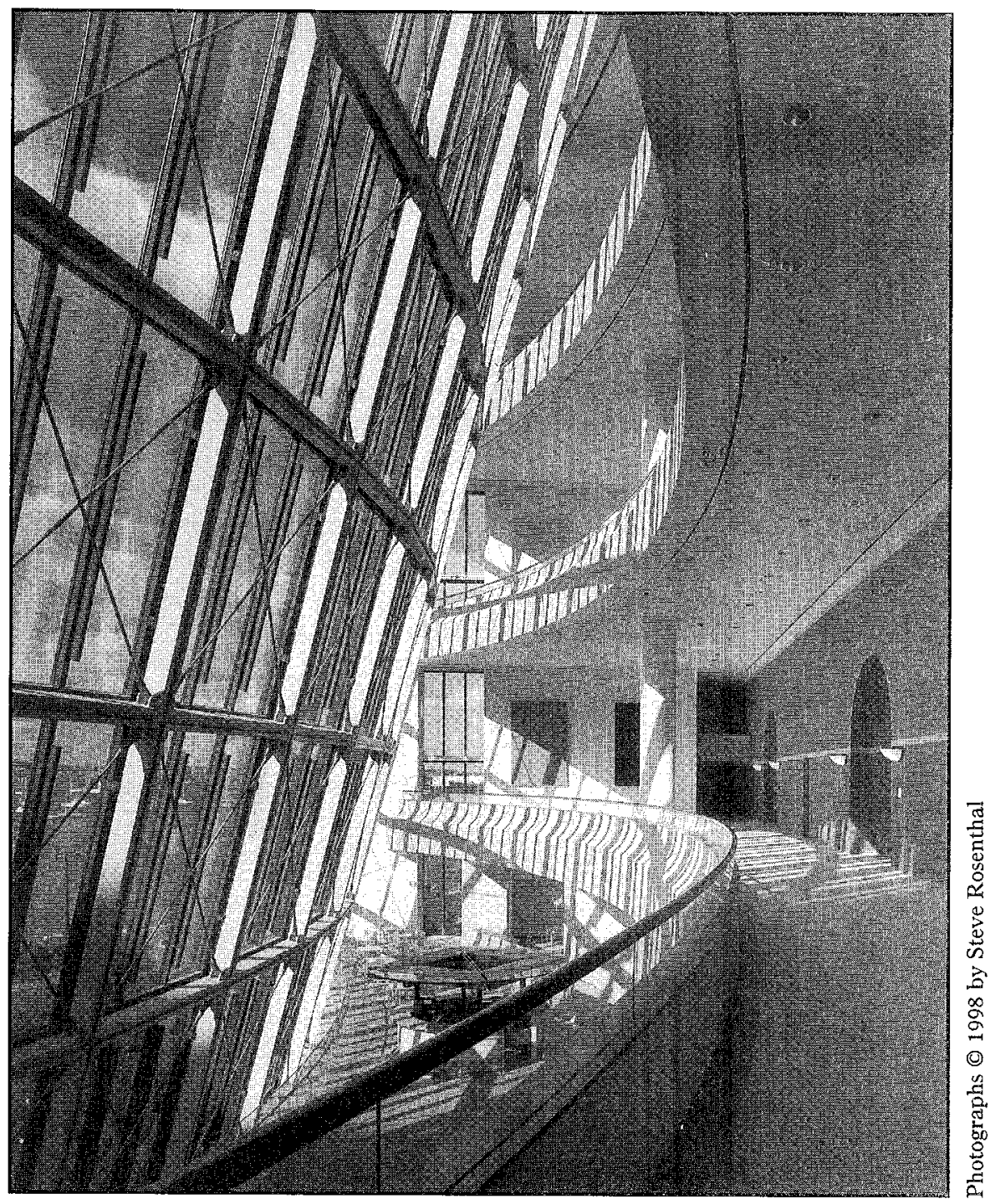

Photo 1: View of the conoid glass wall, of Ellsworth Kelly's panels, and of the arches marking the courtroom entrances. 


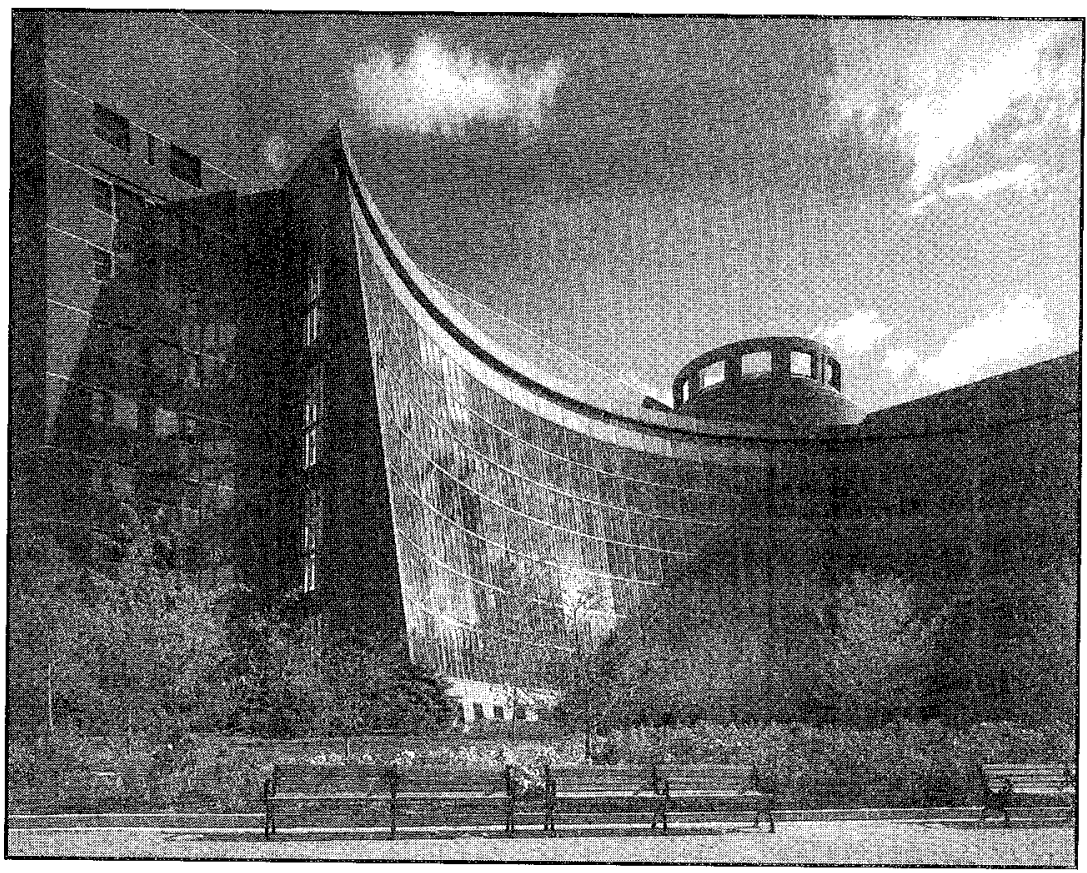

Photo 2: Exterior view of the new federal courthouse in Boston.

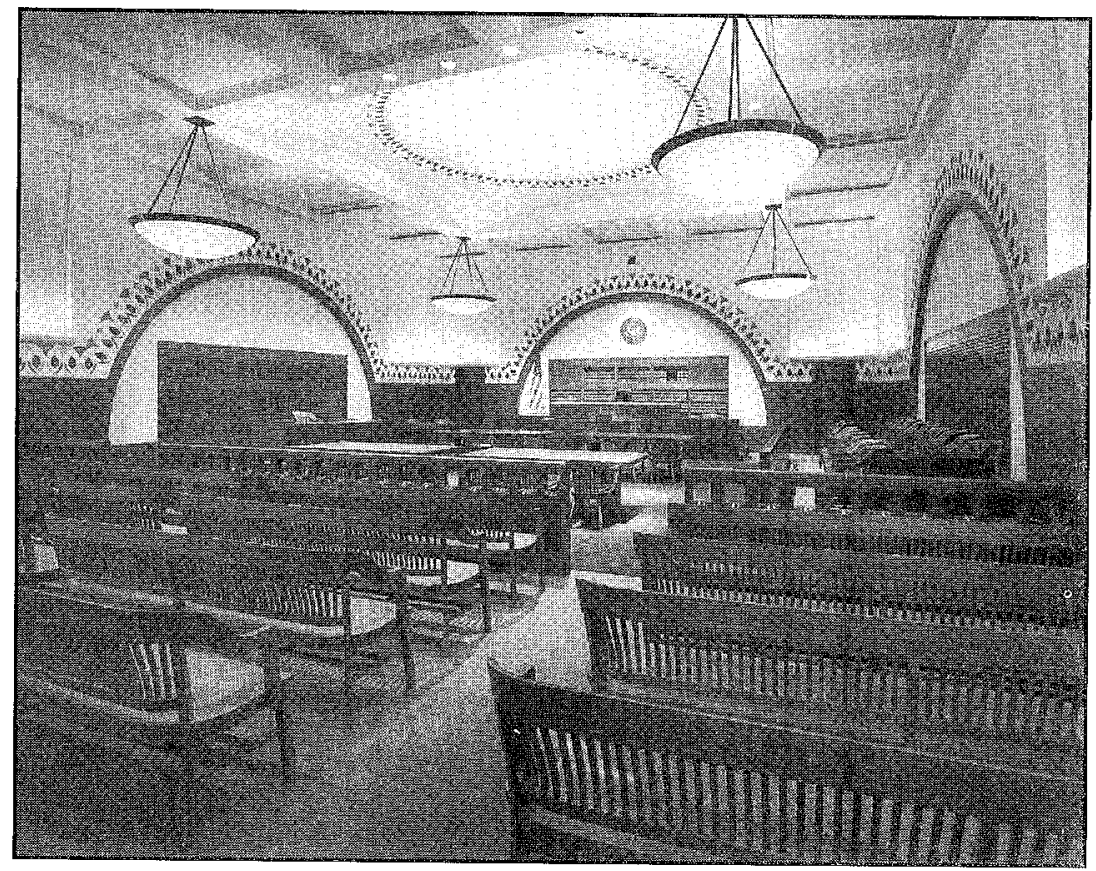

Photo 3: Interior of a courtroom. 


\section{$\mathrm{H}$

Bradley E. Abruzzi

MELISSA J. BaIlY

ANGELA M. BANKS

ROBERT P. BARTLETT, III

TODD F. BRAUNSTEIN

DAVID WYCLIFFE BROWN

GLENN OTIS BROWN

STUART BUCK

Abraham J. B. Cable

JENNIFER L. CANNON

TMMOTHY J. CASEY

EDWARd K. Cheng

EMILY CHIANG

Erica Don Chien

JuLIE E. Cho

AMY CHUNG

SARAH HEATON CONCANNON

DANIEL M. DOCKERY

VICTORIA DORFMAN

ANDREW J. EHRLICH

DMITRY EVSEEV

DAVID FAGUNDES

MATTHEW A. FEIGIN

BRIAN T. FitzPATRICK

JaNE H. FrankEl

ReBECCA J. K. GELFOND

ELIZABETH O. Gill

SHAUN ALARIC GOHO
JASON M. GOLDBERG

JOHN M. GOLDEN

KaTHERINE Goldstein

BRIAN GORDON

SeAN James GrIfFith

J. DAVID GUNTER II

KATHLEEN R. HARTNETT

BRIAN HAUCK

BRUCE W. HICKEY

DEREK Ho

H. JAY HulingS

ALISON S. HUNTER

WiLliam M. JAY

Michael Koltonyuk

PreEthal Krishnamurthy

THOMAS H. LeE

Michael LeITER

RUSSELL L. LIPPMAN

ANN M. LIPTON

JANICE LIU

KWAME J. MANLEY

DAN MARKEL

William M. MCSWAiN

DARRell A. H. MiLler

MichaEe. F. MiraRCHI

STEPHEN MOELLER-SALLY

Charlene Morisseau

JoHN C. NEIMAN, JR.
DAVID A. O'NeIL

AMY OzOLS

JOHN MARK PIERCE

DOUglas M. PRAVDA

Tricia J. PURCELl

GREGORY G. RAPAWY

JOHN H. RAY, III

ANA C. Reyes

MORGAN RickS

MARK L. RIENZI

ALICE RISTROPH

KRISTINE LEPORATI ROBERTS

ALBERTO J. RUISANCHEZ

ERIN RYAN

JOSEPHINE ELIEN SANDLER

GIL SEINFELD

IAN SHAPIRO

ANNE K. SMALl

A. BENJAMIN SPENCER

RACHEL E. SKIFFER

JIM STAIHAR

YURIKO TADA

ERICA TAGGART

SERRIN TURNER

ROSALIND WANG

Christian J. Ward

VERITY WINSHIP

\section{Colleen Verner Circulation Director}

SUSAN J. WALKER Business Manager

\author{
JENNIFER M. NOURSE \\ Editorial Assistant
}

DENIS O'BRIEN Office Assistant

Published eight times during the academic year by Harvard law students.

Citations conform to The Bluebook: A Uniform System of Citation (16th ed. 1996), published by the Harvard Law Review Association for the Columbia Law Review, the Harvard Law Review, the University of Pennsylvania Law Review, and The Yale Law Journal. 